\title{
Users Manual for TMY3 Data Sets
}

S. Wilcox and W. Marion

\section{Technical Report} NREL/TP-581-43156

Revised May 2008
NREL is operated by Midwest Research Institute • Battelle

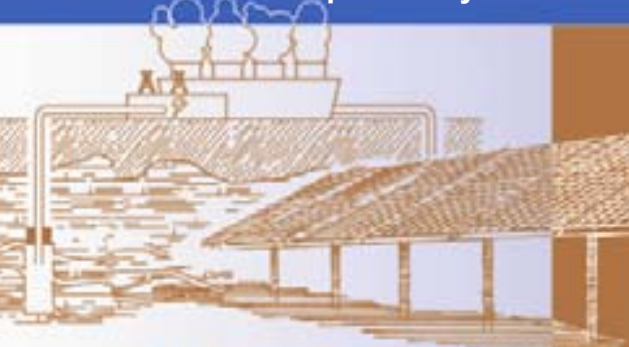

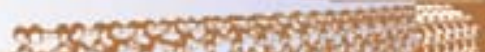
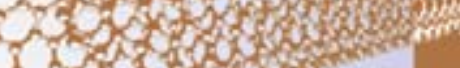

The 10,000

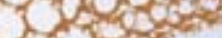

Contract No. DE-AC36-99-G010337

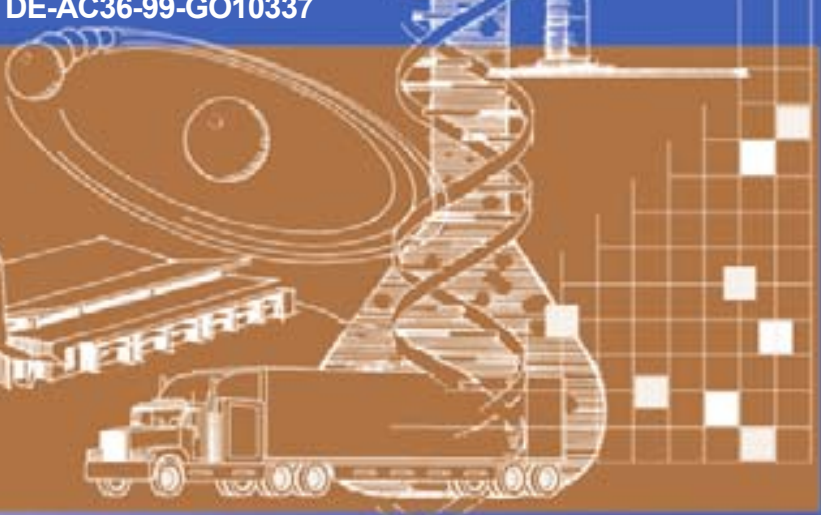




\title{
Users Manual for TMY3 Data Sets
}

\author{
S. Wilcox and W. Marion
}

Prepared under Task No. PVA7.6101

National Renewable Energy Laboratory

1617 Cole Boulevard, Golden, Colorado 80401-3393

303-275-3000 • www.nrel.gov

Operated for the U.S. Department of Energy

Office of Energy Efficiency and Renewable Energy

by Midwest Research Institute • Battelle

Contract No. DE-AC36-99-G010337 


\section{NOTICE}

This report was prepared as an account of work sponsored by an agency of the United States government. Neither the United States government nor any agency thereof, nor any of their employees, makes any warranty, express or implied, or assumes any legal liability or responsibility for the accuracy, completeness, or usefulness of any information, apparatus, product, or process disclosed, or represents that its use would not infringe privately owned rights. Reference herein to any specific commercial product, process, or service by trade name, trademark, manufacturer, or otherwise does not necessarily constitute or imply its endorsement, recommendation, or favoring by the United States government or any agency thereof. The views and opinions of authors expressed herein do not necessarily state or reflect those of the United States government or any agency thereof.

Available electronically at http://www.osti.gov/bridge

Available for a processing fee to U.S. Department of Energy and its contractors, in paper, from:

U.S. Department of Energy

Office of Scientific and Technical Information

P.O. Box 62

Oak Ridge, TN 37831-0062

phone: 865.576 .8401

fax: 865.576 .5728

email: mailto:reports@adonis.osti.gov

Available for sale to the public, in paper, from:

U.S. Department of Commerce

National Technical Information Service

5285 Port Royal Road

Springfield, VA 22161

phone: 800.553.6847

fax: 703.605.6900

email: orders@ntis.fedworld.gov

online ordering: http://www.ntis.gov/ordering.htm 


\section{ERRATA SHEET}

NREL REPORT/PROJECT NUMBER: TP-581-43156

TITLE: Users Manual for TMY3 Data Sets

AUTHORS: S. Wilcox and W. Marion

ORIGINAL PUBLICATION DATE: April 2008

DATE OF CORRECTIONS: May 2008

The following corrections were made to this report:

Pages 4-5: Table 1-3, Lines 6, 9, 12, 15, 18, 21, 24 text changes

Page 8: Table 1-4 replaced 


\section{Preface}

This user's manual describes typical meteorological year (TMY) data sets derived from the 19912005 National Solar Radiation Data Base (NSRDB) update. These data sets provide greater geographical coverage than previous TMY sets with 1020 locations in the United States and its territories.

To distinguish between the old and new data sets, the new TMY data sets are referred to as TMY3. The TMY, TMY2, and TMY3 data sets cannot be used interchangeably because of differences in time (solar versus local), formats, elements, and units. Unless they are revised, computer programs designed for previous TMY data will not work with TMY3 data. The National Renewable Energy Laboratory (NREL) provides a software utility that allows reformatting of the TMY3 data to the TMY2 format.

The TMY data sets hold hourly values of solar radiation and meteorological elements for a 1year period. Their intended use is for computer simulations of solar energy conversion systems and building systems to facilitate performance comparisons of different system types, configurations, and locations in the United States and its territories. Because they represent typical rather than extreme conditions, they are not suited for designing systems to meet the worst-case conditions occurring at a location.

The TMY3 data sets and this manual were produced by NREL's Electric and Systems Center under the Solar Resource Characterization Project, which is funded and monitored by the U.S. Department of Energy's Energy Efficiency and Renewable Energy Office.

\section{Acknowledgements}

The meteorological data used in this data set are provided by the National Climatic Data Center (NCDC) from its Integrated Surface Database (ISD). NREL gratefully acknowledges the countless hours of time and expertise that went into the creation and maintenance of the ISD. More information on the ISD and NCDC is available at http://ncdc.noaa.gov.

We also acknowledge the valuable contributions of the Atmospheric Sciences Research Center (ASRC), State University of New York at Albany. The ASRC team provided much of the modeled solar radiation data in this data set using the SUNY satellite model. 


\section{Table of Contents}

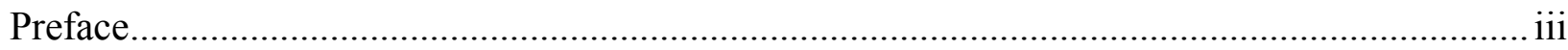

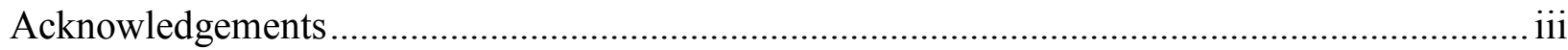

List of Figures ............................................................................................................. iv

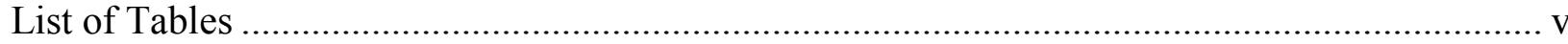

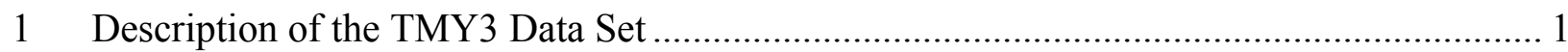

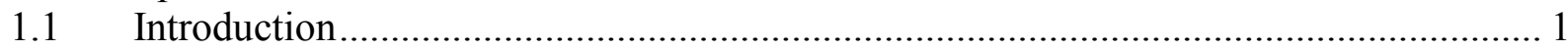

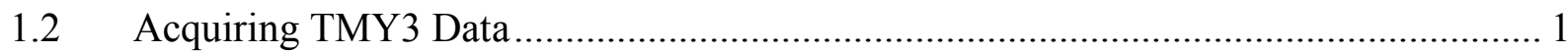

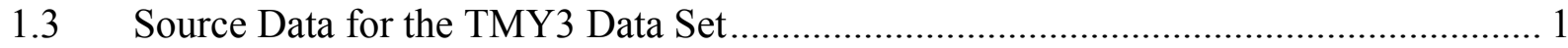

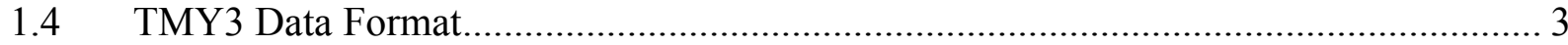

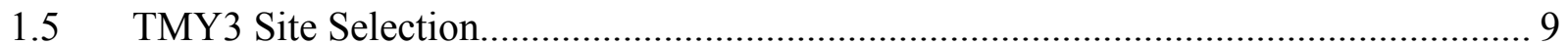

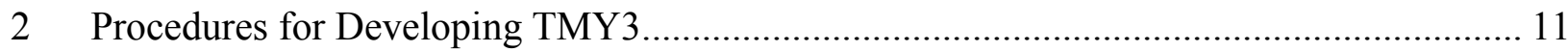

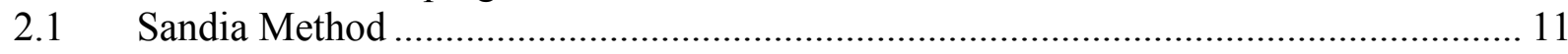

2.2 Weighting and Index Modifications for TMY2 and TMY3 …….............................. 13

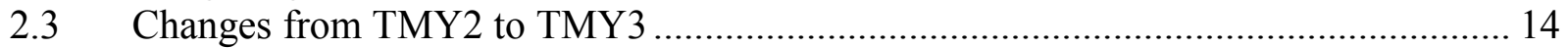

2.4 El Chichón and Mount Pinatubo Years ..................................................................... 14

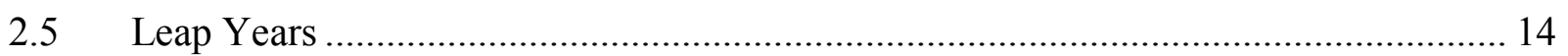

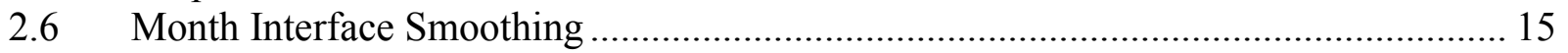

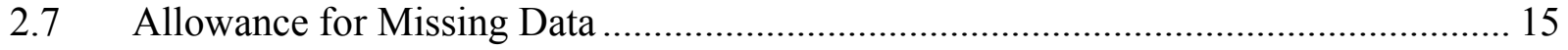

2.8 TMY3 Process Development and Quality Control.................................................. 15

$2.9 \quad$ Calculation of Illuminance Data ......................................................................... 19

2.10 Assignment of Source and Uncertainty Flags.......................................................... 19

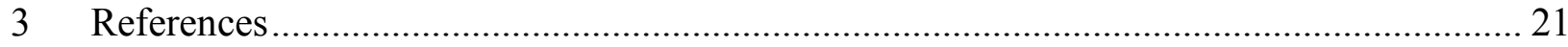

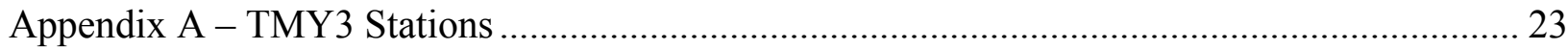

\section{List of Figures}

Figure 2-1. Cumulative distribution functions for June global horizontal solar radiation for Boulder, Colorado (example from TMY2 processing) ............................................................ 12 Figure 2-2. Direct normal delta mean (new minus original 1961-1990) for each evaluation

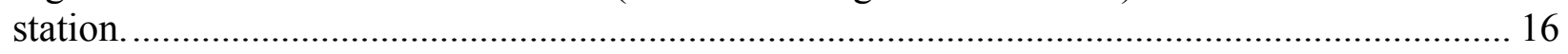
Figure 2-3. Year selection frequency comparison between original 1961-1990 and re-created

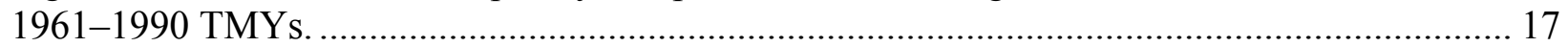

Figure 2-4. Year selection frequency for 30-year 1976-2005 TMY.......................................... 18

Figure 2-5. Year selection frequency for 15-year 1991-2005 TMY......................................... 19 


\section{List of Tables}

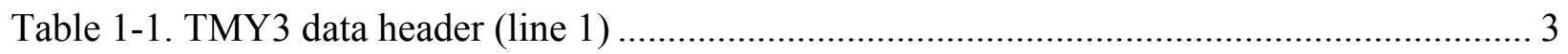

Table 1-2. TMY3 data header (line 2) ............................................................................. 3

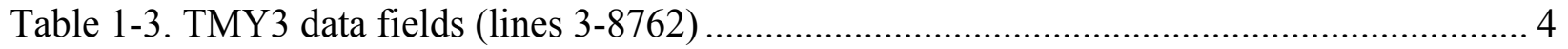

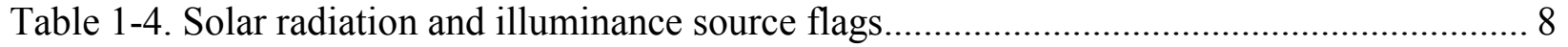

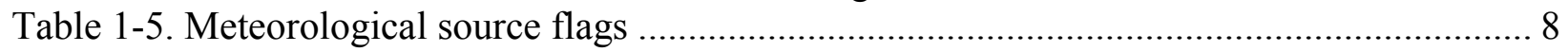

Table 1-6. Meteorological uncertainty flags ................................................................... 8

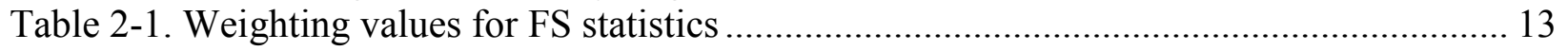

Table 2-2. Bias (test data minus original 61-90 TMY) ...................................................... 17

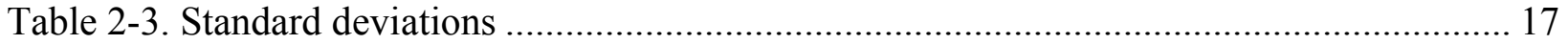

\section{Acronyms}

ASHRAE American Society of Heating, Refrigerating, and Air-Conditioning Engineers

TMY typical meteorological year

NREL National Renewable Energy Laboratory

NSRDB National Solar Radiation Data Base

CSV comma separated value

CDF cumulative distribution functions

FS Finkelstein- Schafer

WS weighted sum 


\section{Description of the TMY3 Data Set}

This manual describes how to obtain and interpret the data in the Typical Meteorological Year, version 3 (TMY3) data sets. These data sets are an update to, and expansion of, the TMY2 data released by the National Renewable Energy Laboratory (NREL) in 1994.

\subsection{Introduction}

A typical meteorological year (TMY) data set provides designers and other users with a reasonably sized annual data set that holds hourly meteorological values that typify conditions at a specific location over a longer period of time, such as 30 years. TMY data sets are widely used by building designers and others for modeling renewable energy conversion systems. Although not designed to provide meteorological extremes, TMY data have natural diurnal and seasonal variations and represent a year of typical climatic conditions for a location. The TMY should not be used to predict weather for a particular period of time, nor is it an appropriate basis for evaluating real-time energy production or efficiencies for building design applications or solar conversion systems.

Important note: Some of the meteorological data in this data set have been filled. The data-filling process was designed to provide serially complete records as input for modeling the solar radiation fields. Filled meteorological data fields (which are flagged in the data file) may also be useful for certain renewable energy applications. However, the filled data are not suitable for climatological studies.

The TMY data set is composed of 12 typical meteorological months (January through December) that are concatenated essentially without modification to form a single year with a serially complete data record for primary measurements. These monthly data sets contain actual time-series meteorological measurements and modeled solar values, although some hourly records may contain filled or interpolated data for periods when original observations are missing from the data archive.

\subsection{Acquiring TMY3 Data}

The TMY3 data are available for download via the World Wide Web. Data may be accessed at http://rredc.nrel.gov/solar/old data/nsrdb/1991-2005/tmy3.

\subsection{Source Data for the TMY3 Data Set}

The first TMY data set for the United States was produced by Sandia National Laboratories in 1978 for 248 locations using long-term weather and solar data from the 1952-1975

SOLMET/ERSATZ database (Hall et al. 1978). NREL updated the TMY data in 1994 using data from the 30-year 1961-1990 National Solar Radiation Data Base (NSRDB) (Marion, et al.

1995). In 2007, NREL released a 15-year updated NSRDB for 1991-2005 (Wilcox et al. 2007a). The TMY3 data described here were produced using input data for 1976-2005 from the 19611990 NSRDB, Version 1.1 and the 1991-2005 NSRDB update.

Because the 1961-1990 NSRDB has 239 sites and the 1991-2005 NSRDB update has more than 1,400 sites, production of the TMY3 data was designed to maximize both the number of stations 
and the number of years from which to characterize the typical conditions. At sites where data are available for 30 years, the base time period for the TMY algorithm spans 1976-2005. For the remaining sites, the base time period spans 1991-2005. These two categories of sites are documented in Appendix A.

In the creation of a TMY, selecting from a larger database generally affords smaller differences between selected data months and long-term monthly characteristics. Conversely, the smaller the pool of years from which to determine climate characteristics, the less likely the selection represents the climate (ASHRAE 2004). In the same context, the eruptions of El Chichón in 1982 and Mt. Pinatubo in 1991 had significant effects on solar radiation for the United States and further reduced the pool of data for determining the typical climate. Volcanic eruptions, while often significantly diminishing solar energy at the earth's surface, are rare, unpredictable, and variable in intensity. Designers may want to know the potential effects of volcanic eruptions to determine worst-case scenarios, but such perturbations do not contribute to long-term climate characterization.

Except for a few changes to the weighting criteria, which account for the relative importance of the solar radiation and meteorological elements, the TMY2 and TMY3 data sets were created using procedures similar to those developed by Sandia National Laboratories (Hall et al. 1978) to create the original TMYs from the 1952-1975 SOLMET/ERSATZ data (see Section 2.1). Minor changes to the algorithm were made between the TMY2 and TMY3 production runs (see Section 2.3). A small change to the persistence criteria better accommodates selecting a TMY month for periods or records with fewer years. Also, computer code was removed that prioritized the selection of months with measured solar data because no measured data were used in the 19912005 NSRDB update. The effects of these changes between the TMY2 and TMY3 algorithm were evaluated as part of the TMY3 production process (see Section 2.8). In the context of producing data sets with similar characteristics, these effects were small (Wilcox, et al. 2008).

The Sandia method is an empirical approach that selects individual months from different years occurring in the period of record. For example, in the case of the NSRDB that contains 30 years of data, all 30 Januarys are examined, and the one judged most typical by the TMY algorithm is selected to be included in the TMY. The other months of the year are treated in a like manner, and then the 12 selected typical months are concatenated to form a complete year.

The 12 selected typical months for each station were chosen using statistics determined by considering five elements: global horizontal radiation, direct normal radiation, dry bulb temperature, dew point temperature, and wind speed. These elements are considered the most important for simulating solar energy conversion systems and building systems.

Because the TMY algorithm assigns priority to the solar radiation elements, the selected months may or may not be typical for other elements. Cloud cover, which correlates well with solar radiation, is probably reasonably typical. Other elements are not related to the elements used for selection; consequently, their values may not be typical. Additionally, even though wind speed was used in the selection of the typical months, its relatively low weighting with respect to the other elements prevents it from being sufficiently typical for simulating wind energy conversion systems. 


\subsection{TMY3 Data Format}

The format for the TMY3 data is radically different from the TMY and TMY2 data.. The older TMY data sets used columnar or positional formats, presumably as a method of optimizing data storage space. Such formats are difficult to read, and it is difficult to import specific fields into many software packages.

The comma separated value (CSV) format is ubiquitous, and many existing programs and applications provide built-in functions to read or parse it. For that reason, the TMY3 data set is distributed in the CSV format. For compatibility with existing software, NREL has produced an application to convert from TMY3 to TMY2 format.

Despite the format differences, the fields in the TMY3 are very similar to those in the TMY2 data set. Fundamental differences are measurement units, which are SI or equivalent in the TMY3, the addition of three new fields for surface albedo and liquid precipitation, and the removal of the fields for present weather, snow-depth, and days since last snowfall that were present in the TMY2. These fields were removed because of incompatible changes in the nature of the source data or because the source data were not available. The TMY3 data files are named according to the USAF site identifier as 999999TY.CSV, where 999999 represents the six digit USAF station identifier (see Appendix A). The TMY3 data format has two file header lines and 8,760 lines of data, each with 68 data fields. The format is documented in Tables 1-1 to 1-3.

Table 1-1. TMY3 data header (line 1)

\begin{tabular}{|c|l|l|}
\hline Field & \multicolumn{1}{|c|}{ Element } & \multicolumn{1}{c|}{ Unit or Description } \\
\hline 1 & Site identifier code & USAF number \\
\hline 2 & Station name & Quote delimited \\
\hline 3 & Station state & Two-letter U.S. Postal abbreviation \\
\hline 4 & Site time zone & Hours from Greenwich, negative west \\
\hline 5 & Site latitude & Decimal degree \\
\hline 6 & Site longitude & Decimal degree \\
\hline 7 & Site elevation & Meter \\
\hline
\end{tabular}

Table 1-2. TMY3 data header (line 2)

\begin{tabular}{|c|c|}
\hline Field & Element \\
\hline $1-68$ & Data field name and units (abbreviation or mnemonic) \\
\hline
\end{tabular}


Table 1-3. TMY3 data fields (lines 3-8762)

\begin{tabular}{|c|c|c|c|c|}
\hline Field & Element & Unit or Range & Resolution & Description \\
\hline 1 & Date & MM/DD/YYYY & -- & Date of data record \\
\hline 2 & Time & $\mathrm{HH}: \mathrm{MM}$ & -- & $\begin{array}{l}\text { Time of data record (local } \\
\text { standard time) }\end{array}$ \\
\hline 3 & $\begin{array}{l}\text { Hourly } \\
\text { extraterrestrial } \\
\text { radiation on a } \\
\text { horizontal surface }\end{array}$ & $\begin{array}{l}\text { Watt-hour per } \\
\text { square meter }\end{array}$ & $1 \mathrm{Wh} / \mathrm{m}^{2}$ & $\begin{array}{l}\text { Amount of solar radiation } \\
\text { received on a horizontal surface } \\
\text { at the top of the atmosphere } \\
\text { during the } 60 \text {-minute period } \\
\text { ending at the timestamp }\end{array}$ \\
\hline 4 & $\begin{array}{l}\text { Hourly } \\
\text { extraterrestrial } \\
\text { radiation normal to } \\
\text { the sun }\end{array}$ & $\begin{array}{l}\text { Watt-hour per } \\
\text { square meter }\end{array}$ & $1 \mathrm{Wh} / \mathrm{m}^{2}$ & $\begin{array}{l}\text { Amount of solar radiation } \\
\text { received on a surface normal to } \\
\text { the sun at the top of the } \\
\text { atmosphere during the } 60 \text { - } \\
\text { minute period ending at the } \\
\text { timestamp }\end{array}$ \\
\hline 5 & $\begin{array}{l}\text { Global horizontal } \\
\text { irradiance }\end{array}$ & $\begin{array}{l}\text { Watt-hour per } \\
\text { square meter }\end{array}$ & $1 \mathrm{Wh} / \mathrm{m}^{2}$ & $\begin{array}{l}\text { Total amount of direct and } \\
\text { diffuse solar radiation received } \\
\text { on a horizontal surface during } \\
\text { the } 60 \text {-minute period ending at } \\
\text { the timestamp }\end{array}$ \\
\hline 6 & $\begin{array}{l}\text { Global horizontal } \\
\text { irradiance source } \\
\text { flag }\end{array}$ & $1-2$ & -- & See Table 1-4 \\
\hline 7 & $\begin{array}{l}\text { Global horizontal } \\
\text { irradiance } \\
\text { uncertainty }\end{array}$ & Percent & $1 \%$ & $\begin{array}{l}\text { Uncertainty based on random } \\
\text { and bias error estimates - see } \\
\text { NSRDB User's Manual (Wilcox, } \\
\text { 2007b) }\end{array}$ \\
\hline 8 & $\begin{array}{l}\text { Direct normal } \\
\text { irradiance }\end{array}$ & $\begin{array}{l}\text { Watt-hour per } \\
\text { square meter }\end{array}$ & $1 \mathrm{Wh} / \mathrm{m}^{2}$ & $\begin{array}{l}\text { Amount of solar radiation } \\
\text { (modeled) received in a } \\
\text { collimated beam on a surface } \\
\text { normal to the sun during the } 60 \text { - } \\
\text { minute period ending at the } \\
\text { timestamp }\end{array}$ \\
\hline 9 & $\begin{array}{l}\text { Direct normal } \\
\text { irradiance source } \\
\text { flag }\end{array}$ & $1-2$ & -- & See table 1-4 \\
\hline 10 & $\begin{array}{l}\text { Direct normal } \\
\text { irradiance } \\
\text { uncertainty }\end{array}$ & Percent & $1 \%$ & $\begin{array}{l}\text { Uncertainty based on random } \\
\text { and bias error estimates - see } \\
\text { NSRDB User's Manual (Wilcox, } \\
\text { 2007b) }\end{array}$ \\
\hline 11 & $\begin{array}{l}\text { Diffuse horizontal } \\
\text { irradiance }\end{array}$ & $\begin{array}{l}\text { Watt-hour per } \\
\text { square meter }\end{array}$ & $1 \mathrm{Wh} / \mathrm{m}^{2}$ & $\begin{array}{l}\text { Amount of solar radiation } \\
\text { received from the sky (excluding } \\
\text { the solar disk) on a horizontal } \\
\text { surface during the } 60 \text {-minute } \\
\text { period ending at the timestamp }\end{array}$ \\
\hline 12 & $\begin{array}{l}\text { Diffuse horizontal } \\
\text { irradiance source } \\
\text { flag }\end{array}$ & $1-2$ & -- & See Table 1-4 \\
\hline 13 & $\begin{array}{l}\text { Diffuse horizontal } \\
\text { irradiance } \\
\text { uncertainty }\end{array}$ & Percent & $1 \%$ & $\begin{array}{l}\text { Uncertainty based on random } \\
\text { and bias error estimates - see } \\
\text { NSRDB User's Manual (Wilcox, } \\
\text { 2007b) }\end{array}$ \\
\hline
\end{tabular}




\begin{tabular}{|c|c|c|c|c|}
\hline 14 & $\begin{array}{l}\text { Global horizontal } \\
\text { illuminance }\end{array}$ & Lux & $100 \mathrm{Ix}$ & $\begin{array}{l}\text { Average total amount of direct } \\
\text { and diffuse illuminance received } \\
\text { on a horizontal surface during } \\
\text { the } 60 \text {-minute period ending at } \\
\text { the timestamp }\end{array}$ \\
\hline 15 & $\begin{array}{l}\text { Global horizontal } \\
\text { illuminance source } \\
\text { flag }\end{array}$ & $1-2$ & -- & See Table 1-4 \\
\hline 16 & $\begin{array}{l}\text { Global horizontal } \\
\text { illuminance } \\
\text { uncertainty }\end{array}$ & Percent & $1 \%$ & $\begin{array}{l}\text { Uncertainty based on random } \\
\text { and bias error estimates - see } \\
\text { section } 2.10 \text { ) }\end{array}$ \\
\hline 17 & $\begin{array}{l}\text { Direct normal } \\
\text { illuminance }\end{array}$ & Lux & $100 \mathrm{Ix}$ & $\begin{array}{l}\text { Average amount of direct } \\
\text { normal illuminance received } \\
\text { within a } 5.7^{\circ} \text { field of view } \\
\text { centered on the sun during } 60 \text { - } \\
\text { minute period ending at the } \\
\text { timestamp }\end{array}$ \\
\hline 18 & $\begin{array}{l}\text { Direct normal } \\
\text { illuminance source } \\
\text { flag }\end{array}$ & $1-2$ & -- & See Table 1-4 \\
\hline 19 & $\begin{array}{l}\text { Direct normal } \\
\text { illuminance } \\
\text { uncertainty }\end{array}$ & Percent & $1 \%$ & $\begin{array}{l}\text { Uncertainty based on random } \\
\text { and bias error estimates - see } \\
\text { section } 2.10 \text { ) }\end{array}$ \\
\hline 20 & $\begin{array}{l}\text { Diffuse horizontal } \\
\text { illuminance }\end{array}$ & Lux & $100 \mathrm{~lx}$ & $\begin{array}{l}\text { Average amount of illuminance } \\
\text { received from the sky (excluding } \\
\text { the solar disk) on a horizontal } \\
\text { surface during the } 60 \text {-minute } \\
\text { period ending at the timestamp }\end{array}$ \\
\hline 21 & $\begin{array}{l}\text { Diffuse horizontal } \\
\text { illuminance source } \\
\text { flag }\end{array}$ & $1-2$ & -- & See Table 1-4 \\
\hline 22 & $\begin{array}{l}\text { Diffuse horizontal } \\
\text { illuminance } \\
\text { uncertainty }\end{array}$ & Percent & $1 \%$ & $\begin{array}{l}\text { Uncertainty based on random } \\
\text { and bias error estimates - see } \\
\text { section } 2.10 \text { ) }\end{array}$ \\
\hline 23 & Zenith luminance & $\begin{array}{l}\text { Candela per } \\
\text { square meter }\end{array}$ & $10 \mathrm{~cd} / \mathrm{m}^{2}$ & $\begin{array}{l}\text { Average amount of luminance at } \\
\text { the sky's zenith during the } 60- \\
\text { minute period ending at the } \\
\text { timestamp }\end{array}$ \\
\hline 24 & $\begin{array}{l}\text { Zenith luminance } \\
\text { source flag }\end{array}$ & $1-2$ & -- & See Table 1-4 \\
\hline 25 & $\begin{array}{l}\text { Zenith luminance } \\
\text { uncertainty }\end{array}$ & Percent & $1 \%$ & $\begin{array}{l}\text { Uncertainty based on random } \\
\text { and bias error estimates - see } \\
\text { section } 2.10 \text { ) }\end{array}$ \\
\hline 26 & Total sky cover & Tenths of sky & 1 tenth & $\begin{array}{l}\text { Amount of sky dome covered by } \\
\text { clouds or obscuring phenomena } \\
\text { at the time indicated }\end{array}$ \\
\hline 27 & $\begin{array}{l}\text { Total sky cover flag } \\
\text { (source) }\end{array}$ & & & See Table 1-5 \\
\hline 28 & $\begin{array}{l}\text { Total sky cover flag } \\
\text { (uncertainty) }\end{array}$ & & & See Table 1-6 \\
\hline 29 & Opaque sky cover & Tenths of sky & 1 tenth & $\begin{array}{l}\text { Amount of sky dome covered by } \\
\text { clouds or obscuring phenomena } \\
\text { that prevent observing the sky } \\
\text { or higher cloud layers at the } \\
\text { time indicated }\end{array}$ \\
\hline
\end{tabular}




\begin{tabular}{|c|c|c|c|c|}
\hline 30 & $\begin{array}{l}\text { Opaque sky cover } \\
\text { flag (source) }\end{array}$ & & & See Table 1-5 \\
\hline 31 & $\begin{array}{l}\text { Opaque sky cover } \\
\text { flag (uncertainty) }\end{array}$ & & & See Table 1-6 \\
\hline 32 & $\begin{array}{l}\text { Dry-bulb } \\
\text { temperature }\end{array}$ & Degree C & $0.1^{\circ}$ & $\begin{array}{l}\text { Dry-bulb temperature at the time } \\
\text { indicated }\end{array}$ \\
\hline 33 & $\begin{array}{l}\text { Dry-bulb } \\
\text { temperature flag } \\
\text { (source) }\end{array}$ & & & See Table 1-5 \\
\hline 34 & $\begin{array}{l}\text { Dry-bulb } \\
\text { temperature flag } \\
\text { (uncertainty) }\end{array}$ & & & See Table 1-6 \\
\hline 35 & $\begin{array}{l}\text { Dew-point } \\
\text { temperature }\end{array}$ & Degree C & $0.1^{\circ}$ & $\begin{array}{l}\text { Dew-point temperature at the } \\
\text { time indicated }\end{array}$ \\
\hline 36 & $\begin{array}{l}\text { Dew-point } \\
\text { temperature flag } \\
\text { (source) }\end{array}$ & & & See Table $1-5$ \\
\hline 37 & $\begin{array}{l}\text { Dew-point } \\
\text { temperature flag } \\
\text { (uncertainty) }\end{array}$ & & & See Table 1-6 \\
\hline 38 & Relative humidity & Percent & $1 \%$ & $\begin{array}{l}\text { Relative humidity at the time } \\
\text { indicated }\end{array}$ \\
\hline 39 & $\begin{array}{l}\text { Relative humidity } \\
\text { flag (source) }\end{array}$ & & & See Table 1-5 \\
\hline 40 & $\begin{array}{l}\text { Relative humidity } \\
\text { flag (uncertainty) }\end{array}$ & & & See Table 1-6 \\
\hline 41 & Station pressure & Millibar & $1 \mathrm{mbar}$ & $\begin{array}{l}\text { Station pressure at the time } \\
\text { indicated }\end{array}$ \\
\hline 42 & $\begin{array}{l}\text { Station pressure flag } \\
\text { (source) }\end{array}$ & & & See Table 1-5 \\
\hline 43 & $\begin{array}{l}\text { Station pressure flag } \\
\text { (uncertainty) }\end{array}$ & & & See Table 1-6 \\
\hline 44 & Wind direction & $\begin{array}{l}\text { Degrees from } \\
\text { north }\left(360^{\circ}=\right. \\
\text { north; } 0^{\circ}= \\
\text { undefined, } \\
\text { calm) }\end{array}$ & $10^{\circ}$ & $\begin{array}{l}\text { Wind direction at the time } \\
\text { indicated }\end{array}$ \\
\hline 45 & $\begin{array}{l}\text { Wind direction flag } \\
\text { (source) }\end{array}$ & & & See Table 1-5 \\
\hline 46 & $\begin{array}{l}\text { Wind direction flag } \\
\text { (uncertainty) }\end{array}$ & & & See Table 1-6 \\
\hline 47 & Wind speed & Meter/second & $0.1 \mathrm{~m} / \mathrm{s}$ & $\begin{array}{l}\text { Wind speed at the time } \\
\text { indicated }\end{array}$ \\
\hline 48 & $\begin{array}{l}\text { Wind speed flag } \\
\text { (source) }\end{array}$ & & & See Table 1-5 \\
\hline 49 & $\begin{array}{l}\text { Wind speed flag } \\
\text { (uncertainty) }\end{array}$ & & & See Table 1-6 \\
\hline 50 & Horizontal visibility & Meter* & $1 \mathrm{~m}$ & $\begin{array}{l}\text { Distance to discernable remote } \\
\text { objects at the time indicated } \\
\text { ( } 7777=\text { unlimited })\end{array}$ \\
\hline 51 & $\begin{array}{l}\text { Horizontal visibility } \\
\text { flag (source) }\end{array}$ & & & See Table 1-5 \\
\hline 52 & $\begin{array}{l}\text { Horizontal visibility } \\
\text { flag (uncertainty) }\end{array}$ & & & \\
\hline
\end{tabular}




\begin{tabular}{|c|c|c|c|c|}
\hline 53 & Ceiling height & Meter $^{*}$ & $1 \mathrm{~m}$ & $\begin{array}{l}\text { Height of the cloud base above } \\
\text { local terrain }(77777=\text { unlimited })\end{array}$ \\
\hline 54 & $\begin{array}{l}\text { Ceiling height flag } \\
\text { (source) }\end{array}$ & & & See Table 1-5 \\
\hline 55 & $\begin{array}{l}\text { Ceiling height flag } \\
\text { (uncertainty) }\end{array}$ & & & See Table 1-6 \\
\hline 56 & Precipitable water & Centimeter & $0.1 \mathrm{~cm}$ & $\begin{array}{l}\text { The total precipitable water } \\
\text { contained in a column of unit } \\
\text { cross section extending from the } \\
\text { earth's surface to the top of the } \\
\text { atmosphere }\end{array}$ \\
\hline 57 & $\begin{array}{l}\text { Precipitable water } \\
\text { flag (source) }\end{array}$ & & & See Table 1-5 \\
\hline 58 & $\begin{array}{l}\text { Precipitable water } \\
\text { flag (uncertainty) }\end{array}$ & & & See Table 1-6 \\
\hline 59 & $\begin{array}{l}\text { Aerosol optical } \\
\text { depth, broadband }\end{array}$ & [unitless] & 0.001 & $\begin{array}{l}\text { The broadband aerosol optical } \\
\text { depth per unit of air mass due to } \\
\text { extinction by the aerosol } \\
\text { component of the atmosphere }\end{array}$ \\
\hline 60 & $\begin{array}{l}\text { Aerosol optical } \\
\text { depth, broadband } \\
\text { flag (source) }\end{array}$ & & & See Table 1-5 \\
\hline 61 & $\begin{array}{l}\text { Aerosol optical } \\
\text { depth, broadband } \\
\text { flag (uncertainty) }\end{array}$ & & & See Table 1-6 \\
\hline 62 & Albedo & [unitless] & 0.01 & $\begin{array}{l}\text { The ratio of reflected solar } \\
\text { irradiance to global horizontal } \\
\text { irradiance }\end{array}$ \\
\hline 63 & Albedo flag (source) & & & See Table 1-5 \\
\hline 64 & $\begin{array}{l}\text { Albedo flag } \\
\text { (uncertainty) }\end{array}$ & & & See Table 1-6 \\
\hline 65 & $\begin{array}{l}\text { Liquid precipitation } \\
\text { depth }\end{array}$ & Millimeter ${ }^{*}$ & $1 \mathrm{~mm}$ & $\begin{array}{l}\text { The amount of liquid } \\
\text { precipitation observed at the } \\
\text { indicated time for the period } \\
\text { indicated in the liquid } \\
\text { precipitation quantity field }\end{array}$ \\
\hline 66 & $\begin{array}{l}\text { Liquid precipitation } \\
\text { quantity }\end{array}$ & Hour* & $1 \mathrm{hr}$ & $\begin{array}{l}\text { The period of accumulation for } \\
\text { the liquid precipitation depth } \\
\text { field }\end{array}$ \\
\hline 67 & $\begin{array}{l}\text { Liquid precipitation } \\
\text { depth flag (source) }\end{array}$ & & & See Table 1-5 \\
\hline 68 & $\begin{array}{l}\text { Liquid precipitation } \\
\text { depth flag } \\
\text { (uncertainty) }\end{array}$ & & & See Table 1-6 \\
\hline
\end{tabular}

*Value of -9900 indicates the measurement is missing. 
Table 1-4. Solar radiation and illuminance source flags

\begin{tabular}{|l|l|}
\hline Flag & Definition \\
\hline 1 & Data modeled using METSTAT or from 1961-1990 NSRDB solar fields \\
\hline 2 & Data modeled using SUNY Satellite model (time shifted) \\
\hline
\end{tabular}

Table 1-5. Meteorological source flags

\begin{tabular}{|l|l|}
\hline Flag & \multicolumn{1}{|c|}{ Definition } \\
\hline A & Data as received from NCDC, converted to SI units \\
\hline B & Linearly interpolated \\
\hline C & Non-linearly interpolated to fill data gaps from 6 to 47 hours in length \\
\hline D & $\begin{array}{l}\text { Not used } \\
\text { temperature calculated from dry bulb temperature and relative humidity; and relative humidity } \\
\text { calculated from dry bulb temperature and dew point temperature }\end{array}$ \\
\hline E & $\begin{array}{l}\text { Precipitable water, calculated from surface vapor pressure; aerosol optical depth, estimated from } \\
\text { geographic correlation }\end{array}$ \\
\hline F & \begin{tabular}{l} 
Source does not fit any of the above. Used mostly for missing data \\
\hline$?$
\end{tabular} \\
\hline
\end{tabular}

Table 1-6. Meteorological uncertainty flags

\begin{tabular}{|l|l|}
\hline Flag & Not used \\
\hline $1-6$ & $\begin{array}{l}\text { Uncertainty consistent with NWS practices and the instrument or observation } \\
\text { used to obtain the data }\end{array}$ \\
\hline 7 & Greater uncertainty than 7 because values were interpolated or estimated \\
\hline 8 & Greater uncertainty than 8 or unknown \\
\hline 0 & Not definable \\
\hline
\end{tabular}




\subsection{TMY3 Site Selection}

While planning the TMY3 update project, we considered two possible scenarios for populating the data set:

- Create a TMY based on the 30 most recent years of data (1976-2005) for only the 239 sites common to both the old NSRDB and the NSRDB update

- Create a TMY based on the 15 most recent years of data (1991-2005) for approximately 950 sites from the NSRDB update.

To optimize both temporal and spatial considerations, the TMY3 combines these scenarios so that the 30-year data were used at sites where they were available and the 15 -year data were used for the remaining sites. The TMY3 sites are listed in Appendix A. The sites in the 1991-2005 NSRDB were chosen based on data availability rather than geographic location (all sites meeting minimum data criteria were included). For this reason, in the both the NSRDB update and the TMY3, sites may occur in close proximity, for example in major metropolitan areas.

The period of record of the source data set has an effect on the ability of the TMY algorithm to select a typical year (ASHRAE 2004). Because of differences in the source period of record for sites, this information has been documented in Appendix A. See Section 2.8 for a discussion of the effect of available data on the TMY statistics. Note that for the 30 -year period, the pool is reduced to 24 years at best because of the removal of candidate years due to volcanic eruptions (see Section 2.4). For the 15-year period, the pool is reduced to 12 years at best for the same reason. Although some studies have shown than as few as five years may suffice for capturing much of the statistical character of a climate (Vignola 1993), we implemented a more conservative constraint on the size of the source data pool: No stations with less than a ten-year data pool were included in the TMY3 data set.

The NSRDB update subdivided stations by class: Class I sites are those with the lowest uncertainty data, Class II sites have higher uncertainty data, and Class III sites have an incomplete period of record. When creating TMY data sets, we did not consider the class of the site or the uncertainty of the source data. Further, although Class III sites have gaps in the data, the TMY algorithm was able to produce a typical year for many Class III sites using months of data without gaps. To aid users in analyzing the quality of the data, we have included the station's quality classification from the NSRDB update in Appendix A. The NSRDB classification subdivided stations according to the following algorithm:

- If any data were missing from the key fields (solar, temperature, humidity, station pressure, wind speed, aerosols, and precipitable water), the station received a Class III designation. The algorithm distinguishes between Class I and Class II stations by examining the uncertainty for each hourly modeled value in the global field. If less than $25 \%$ of the data for the 15 -year period of record exceeds an uncertainty of $11 \%$, the station received a Class I designation. Otherwise, it received a Class II designation. Although the $11 \%$ threshold between high and low uncertainty may seem arbitrary, based on the uncertainty calculations in the NSRDB update, this value easily discriminates between the data modeled with good human-observed or satellite-derived cloud cover and the filled or statistically derived cloud cover. 
Although the TMY data set likely does not have the same distribution of quality flags for a station as the entire period of record (it could be better or worse), the NSRDB classification scheme is valid for estimating the quality of a station's TMY. This follows because the NSRDB classification is relevant to the quality of the long-term statistics used to choose the data that ultimately represent the site's climate in the TMY. Although the Class III designation focused on data completeness rather than data quality, the data from most Class III stations were similar in quality to those of Class II stations and should be considered comparable when considering data quality in the TMY3 data set.

The geographical coordinates listed in Appendix A may not exactly correspond with the coordinates of the meteorological station. This is because if a site in the NSRDB update held measured data from a nearby solar measurement site, the NSRDB site took on the coordinates of the solar measurement station. See the NSRDB Users' Manual for additional information (Wilcox 2007b). (Measured solar data from the 1991-2005 NSRDB Update were not used in the TMY3 production in order to provide a more consistent data set.) 


\section{Procedures for Developing TMY3}

The TMY2 andTMY3 data were created based on the procedures developed by Sandia National Laboratories (Hall et al. 1978) to create the original TMYs from the 1952-1975

SOLMET/ERSATZ data. Modifications to the Sandia method were made to better optimize the weighting of the indices, to provide preferential selection for months with measured solar radiation data (in the TMY2 data set), and to account for missing data. This section begins by summarizing the Sandia method, and then it discusses departures from the Sandia method that were used to create the TMY3 data.

\subsection{Sandia Method}

The Sandia method is an empirical approach that selects individual months from different years of the period of record. For example, in the case of the NSRDB that contains 30 years of data, all 30 Januarys are examined, and the one judged most typical is selected to be included in the TMY. The other months of the year are treated in a like manner, and then the 12 selected typical months are concatenated to form a complete year. Because adjacent months in the TMY may be selected from different years, discontinuities at the month interfaces are smoothed for 6 hours on each side.

The Sandia method selects a typical month based on nine daily indices consisting of the maximum, minimum, and mean dry bulb and dew point temperatures; the maximum and mean wind velocity; and the total global horizontal solar radiation. Final selection of a month includes consideration of the monthly mean and median and the persistence of weather patterns. The process may be considered a series of steps.

Step 1 - For each month of the calendar year, five candidate months with cumulative distribution functions (CDFs) for the daily indices that are closest to the long-term (30 years for the NSRDB) CDFs are selected. The CDF gives the proportion of values that are less than or equal to a specified value of an index.

Candidate monthly CDFs are compared to the long-term CDFs by using the following Finkelstein- Schafer (FS) statistics (Finkelstein and Schafer 1971) for each index.

$$
F S=(1 / n) \sum_{i=1}^{n} \delta_{i}
$$

where

$\delta_{i}=$ absolute difference between the long-term CDF and the candidate month CDF at $\mathrm{x}_{\mathrm{i}}$

$\mathrm{n}=$ the number of daily readings in a month.

Four CDFs for global horizontal solar radiation for the month of June are shown in Figure 2-1. Using the FS statistic and comparing to the long-term, the CDF for June of 1981 compared the best and the CDF for June of 1989 compared the worst. Even though it was not the best month with respect to the long-term CDF, June of 1962 was selected for the TMY2. This was a consequence of additional selection steps described in the following paragraphs. 


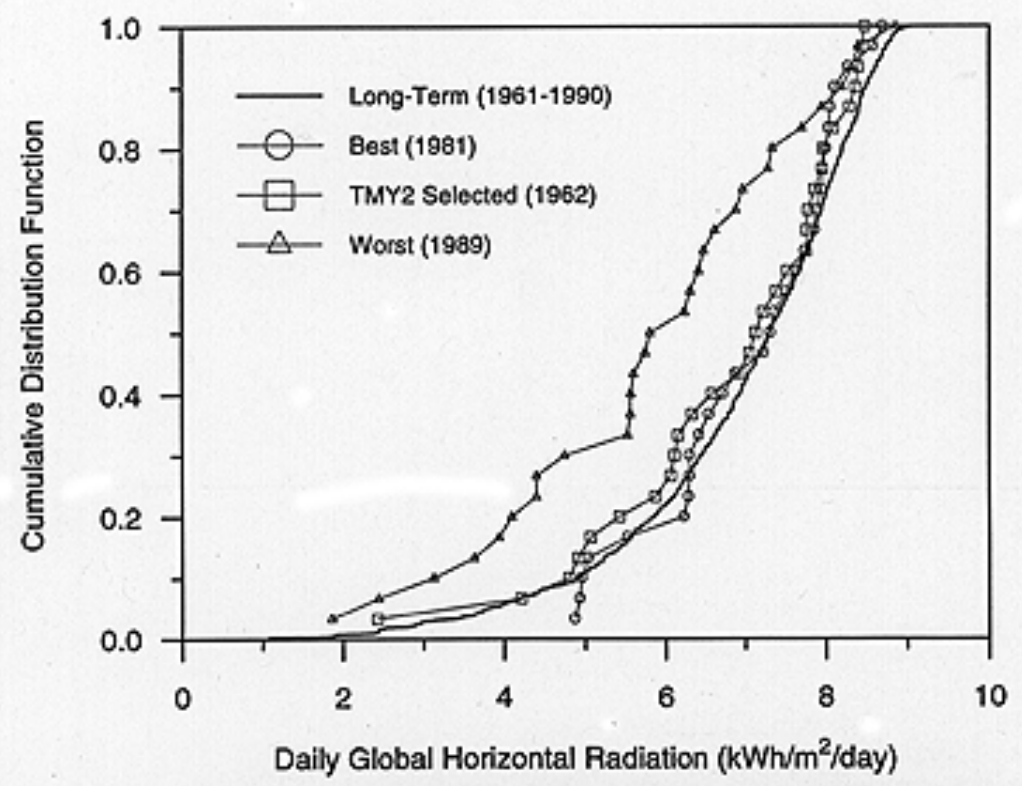

Figure 2-1. Cumulative distribution functions for June global horizontal solar radiation for Boulder, Colorado (example from TMY2 processing).

Because some of the indices are judged more important than others, a weighted sum (WS) of the FS statistics is used to select the five candidate months that have the lowest weighted sums.

$$
W S=\Sigma w_{i} F S_{i}
$$

where

$\mathrm{w}_{\mathrm{i}}=$ weighting for index

$\mathrm{FS}_{\mathrm{i}}=\mathrm{FS}$ statistic for index.

Step 2 - The five candidate months are ranked with respect to closeness of the month to the longterm mean and median.

Step 3 - The persistence of mean dry bulb temperature and daily global horizontal radiation are evaluated by determining the frequency and length of runs of consecutive days with values above and below fixed long-term percentiles. For mean daily dry bulb temperature, runs above the 67 th percentile (consecutive warm days) and below the 33rd percentile (consecutive cool days) were determined. For global horizontal radiation, the runs below the 33rd percentile (consecutive low radiation days) were determined.

The persistence criteria excludes the month with the longest run, the month with the most runs, and the month with zero runs. The persistence data are used to select from the five candidate months the month to be used in the TMY. The highest-ranked candidate month from Step 2 that meets the persistence criteria is used in the TMY.

Step 4 - The 12 selected months were concatenated to make a complete year and discontinuities at the month interfaces were smoothed for 6 hours each side using curve fitting techniques. 


\subsection{Weighting and Index Modifications for TMY2 and TMY3}

The weighting for each index plays a role in the selection of the typical months. Ideally, one would select a month that had FS statistics for each index that were better than all the other months. In practice, this is unlikely because the months might be typical with respect to some of the indices, but not others. By weighting the FS statistics, the relative importance and sensitivity of the indices may be taken into account. The Sandia weighting values and the weighting values used for the NSRDB TMY2 and TMY3 data sets are compared in Table 2-1.

Table 2-1. Weighting values for FS statistics

\begin{tabular}{|l|l|l|}
\hline Index & Sandia Method & NSRDB TMY \\
\hline Max Dry Bulb Temp & $1 / 24$ & $1 / 20$ \\
\hline Min Dry Bulb Temp & $1 / 24$ & $1 / 20$ \\
\hline Mean Dry Bulb Temp & $2 / 24$ & $2 / 20$ \\
\hline Max Dew Point Temp & $1 / 24$ & $1 / 20$ \\
\hline Min Dew Point Temp & $1 / 24$ & $1 / 20$ \\
\hline Mean Dew Point Temp & $2 / 24$ & $2 / 20$ \\
\hline Max Wind Velocity & $2 / 24$ & $1 / 20$ \\
\hline Mean Wind Velocity & $2 / 24$ & $1 / 20$ \\
\hline Global Radiation & $12 / 24$ & $5 / 20$ \\
\hline Direct Radiation & Not Used & $5 / 20$ \\
\hline
\end{tabular}

For the TMY2 and TMY3 data, an index for direct normal radiation was added. This improves the agreement between annual direct normal radiation for the TMY and the 30-year annual average by about a factor of 2 (based on 20 geographically representative NSRDB stations). When only global horizontal radiation is used for the solar index, the TMY annual direct radiation values for the 20 stations were within $4 \%$ (95\% confidence level) of the 30-year annual average. Using both global horizontal and direct radiation indices reduced the differences to $2 \%$, with no adverse effect on global horizontal radiation comparisons.

We changed the weightings for dry bulb and dew point temperatures slightly to give more emphasis to dry bulb and dew point temperatures and less to wind velocity, which is of less importance for solar energy conversion systems and buildings. The TMY weightings are not appropriate for creating a typical wind data set for use with wind energy conversion systems, and these data sets are not intended for wind energy applications.

The relative weights between solar and the other elements were not found to be particularly sensitive. As an indicator, annual heating and cooling degree days (base $\left.18.3^{\circ} \mathrm{C}\right)$ were compared for the TMY2 data and the 30 -year period for the 20 stations. With the selected solar weighting 
of 50\% (global and direct), annual heating degree days for the TMY2 data were within 5\% (95\% confidence level) of the 30-year annual average. As an extreme, reducing the solar weighting to zero only reduced the differences to within $2.5 \%$. Differences between the TMY2 annual averages and the 30-year averages for cooling degree days were within $9 \%$, for both $0 \%$ and $50 \%$ solar weightings.

As a consequence of adding the index for direct normal radiation, the persistence check in Step 3 was modified to determine the frequency and run length below the 33rd percentile (consecutive low radiation days) for daily values of direct normal radiation. This information, along with that for the other persistence indices, was then used to select the month satisfying the persistence criteria.

\subsection{Changes from TMY2 to TMY3}

A few changes from the TMY2 procedures were required to accommodate the use of 1991-2005 NSRDB data in TMY3 data derived from only a 15-year period. For TMY2 data, months with measured solar radiation data were given preferential ranking for selection as a typical month. TMY3 procedures did not include this criterion because only modeled solar radiation data were included in the TMY3 data in order to provide more consistent solar radiation values.

For the TMY3 data, using only 15 years instead of 30 years to select a candidate month required that the persistence checks be relaxed to ensure that a candidate month would be selected. For the TMY2 data, a candidate month is excluded from further consideration if it is the month with the most runs. For TMY3, a candidate month is only excluded if it has more runs than every other candidate month. Consequently, if two candidate months tie for the most runs, neither is eliminated by the TMY3 procedure, whereas the TMY2 procedure would eliminate both candidate months. As an additional step, if the TMY3 persistence procedure eliminated all candidate months, persistence was ignored for TMY3 and a month was selected from the candidate months that was closest to the long term mean and median. This ensured the selection of a typical month for TMY3 using 15-year or shorter data sets. No TMY for a site was produced if the pool of data was less than 10 years.

\subsection{El Chichón and Mount Pinatubo Years}

The volcanic eruptions of El Chichón in Mexico in March 1982 and Mount Pinatubo in the Philippines in June 1991 injected large amounts of aerosols into the stratosphere. The aerosols spread northward and circulated around the earth. This phenomenon noticeably decreased the amount of solar radiation reaching the United States during May 1982 until December 1984 due to El Chichón and from June 1991 to December 1994 due to Pinatubo, after which the effects of the aerosols diminished (Stoffel, 1993). Consequently, these months were not used in any of the TMY procedures because they were considered atypical.

\subsection{Leap Years}

TMY2 and TMY3 files do not include data for February 29. Consequently, data for February 29 were not used in leap year Februarys to determine their candidate month CDFs. However, to maximize the use of available data, data for February 29 were included for determining the longterm CDFs. 


\subsection{Month Interface Smoothing}

We used linear curve-fitting techniques to remove discontinuities created by concatenating months from different years to form the TMY2 and TMY3 data sets. These techniques were applied for 6 hours on each side of the month interfaces for dry bulb temperature, dew point temperature, wind speed, wind direction, atmospheric pressure, and precipitable water. Relative humidity for 6 hours on each side of the month interfaces was calculated using psychometric relationships (ASHRAE 1993) and curve-fitted values of dry bulb temperature and dew point temperature.

\subsection{Allowance for Missing Data}

The NSRDB has no missing solar radiation data for the sites used for TMY production, but meteorological data are missing for some stations and months for the 1961-1990 period. Consequently, when creating the TMY2 data, procedures were adopted to account for missing meteorological data. These procedures are documented in the TMY2 data manual (Marion, et al. 1995). Similar data procedures were developed for filling the 1991-2005 NSRDB data. For the TMY3 data, these procedures (Wilcox, 2007b) were used to fill missing data for the 1976-1990 period. Hence, in the TMY3 update, there was no need for additional data filling as part of the TMY3 algorithm.

\subsection{TMY3 Process Development and Quality Control}

To help guide our development and process validation for the TMY3, we re-created a 1961-1990 TMY with the updated software using data from the TD3282 NSRDB data set distributed by the National Climatic Data Center. Missing meteorological fields were filled according to methods used for the 1991-2005 NSRDB update. In addition, to evaluate the effects of drawing from differing periods of time for the input data set, we compared each of the following year-span subgroups using the original 1961-1990 TMY data set as a benchmark (Wilcox, et al., 2008).

- 1961-1990 (30 years for evaluating software algorithm changes)

- 1976-2005 (for evaluating an updated TMY from a 30-year data set)

- 1991-2005 (for evaluating an updated TMY from a 15-year data set)

- 1998-2005 (for evaluating an updated TMY from an 8-year data set).

The TMY software was run on each data set to create TMYs for the 233 sites common to all subgroups (several sites among the 239 in the TMY2 data set did not have sufficient data for this analysis). We calculated a mean value for each parameter by site for each sub-group TMY. Although means are only a minor consideration in the TMY algorithm, they are one characteristic of climate and are a simple method of detecting large shifts or errors. The differences in means between the original 1961-1990 TMY and the subgroups for direct normal are shown in Figure 2-2. Separate plot curves are shown for each year-span subgroup. 


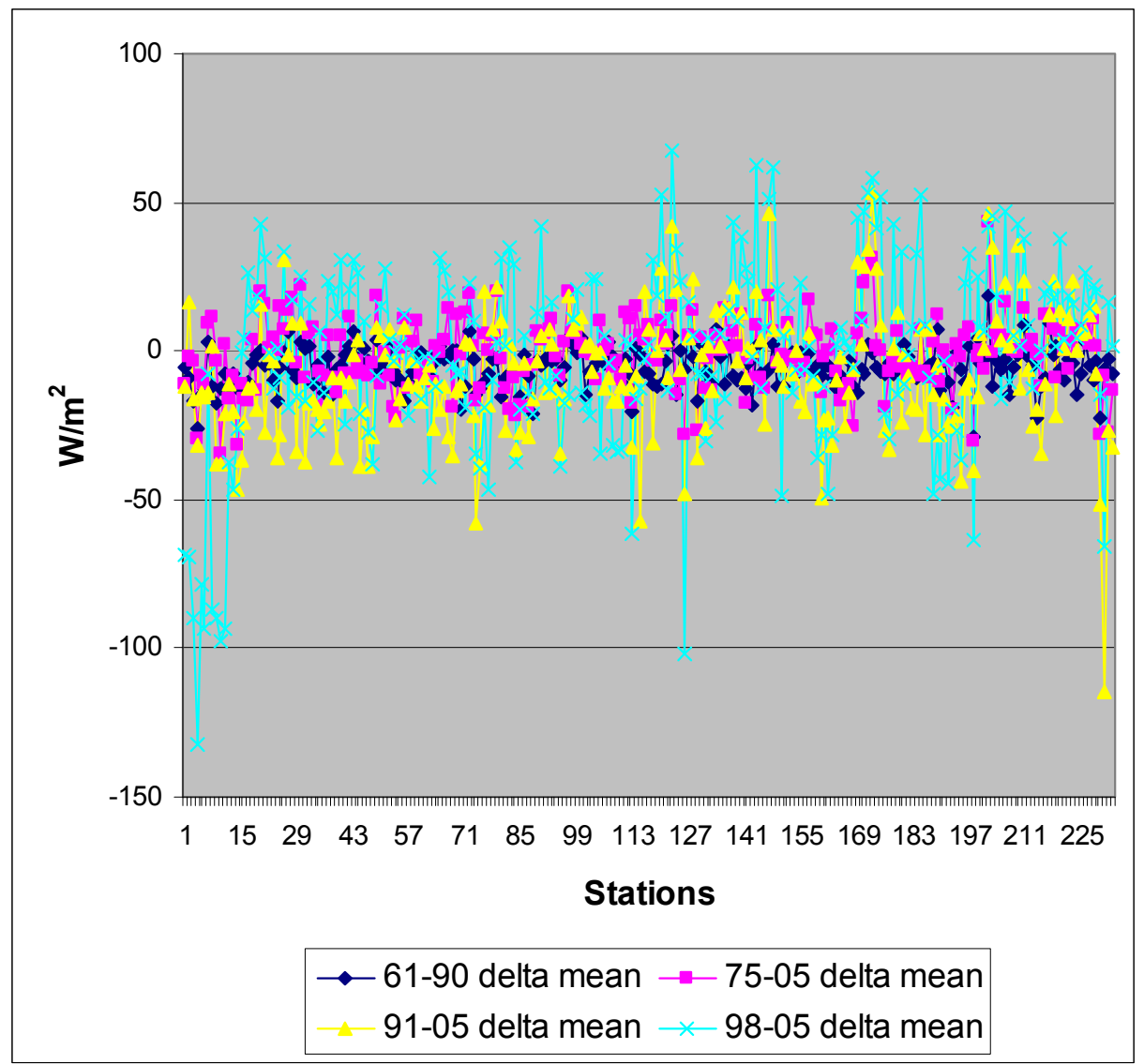

Figure 2-2. Direct normal delta mean (new minus original 1961-1990) for each evaluation station.

The data in this plot show the least scatter when comparing the original and the re-created 19611990 TMYs. For each of the remaining TMYs in order (1976-2005, 1991-2005, and 19982005), increasing scatter is evident compared with the original 1961-1990 TMY. These results are consistent with findings that smaller source data sets are less likely to accurately typify the climate. Also conspicuous are data to the far left in each figure, which correspond to stations in Alaska, where several sites show anomalous values for the 1998-2005 subgroup. At the far right are stations in Hawaii, where other anomalies occur. Further study is required to understand these larger departures.

Tables 2-1 and 2-2 hold summary data showing the means and standard deviations for these comparison data sets. The statistics are found by determining the mean of sunup data for the solar parameters and the mean of all data for meteorological parameters. Biases are determined as the test TMY data set minus the original 61-90 TMY. This information may give the user some indication of the increased uncertainty in the data with the smaller source data sets. 
Table 2-2. Bias (test data minus original 61-90 TMY)

\begin{tabular}{|c|c|c|c|c|}
\hline Parameter & '61-'90 & '76-'05 & '91-'05 & '98-'05 \\
\hline Direct $\mathrm{W} / \mathrm{m}^{2}$ & -5.9 & -1.1 & -7.9 & -1.7 \\
\hline Global W/m $\mathrm{m}^{2}$ & -4.0 & -5.7 & -15.2 & -11.7 \\
\hline Dry Bulb ${ }^{\circ} \mathrm{C}$ & 0.07 & 0.39 & 0.77 & 0.94 \\
\hline Dew Point ${ }^{\circ} \mathrm{C}$ & 0.08 & 0.33 & 0.81 & 1.08 \\
\hline Wind Speed $\mathrm{m} / \mathrm{s}$ & 0.02 & -0.1 & -0.3 & -0.4 \\
\hline
\end{tabular}

Table 2-3. Standard deviations

\begin{tabular}{|c|c|c|c|c|}
\hline Parameter & $91-90$ & $976-05$ & '91-'05 & '98-'05 \\
\hline Direct $\mathrm{W} / \mathrm{m}^{2}$ & 6.7 & 11.9 & 21.0 & 32.5 \\
\hline Global W/m ${ }^{2}$ & 2.8 & 5.3 & 10.0 & 15.1 \\
\hline Dry Bulb ${ }^{\circ} \mathrm{C}$ & 0.22 & 0.37 & 0.49 & 0.77 \\
\hline Dew Point ${ }^{\circ} \mathrm{C}$ & 0.28 & 0.43 & 0.57 & 0.82 \\
\hline Wind Speed m/s & 0.12 & 0.20 & 0.30 & 0.34 \\
\hline
\end{tabular}

To further compare and validate the process, we looked at the frequency of each year's selection for the year-span subgroups. Figure 2-3 shows the comparison between the year selection frequencies of the original 1961-1990 TMY and the re-created 1961-1990 TMY.

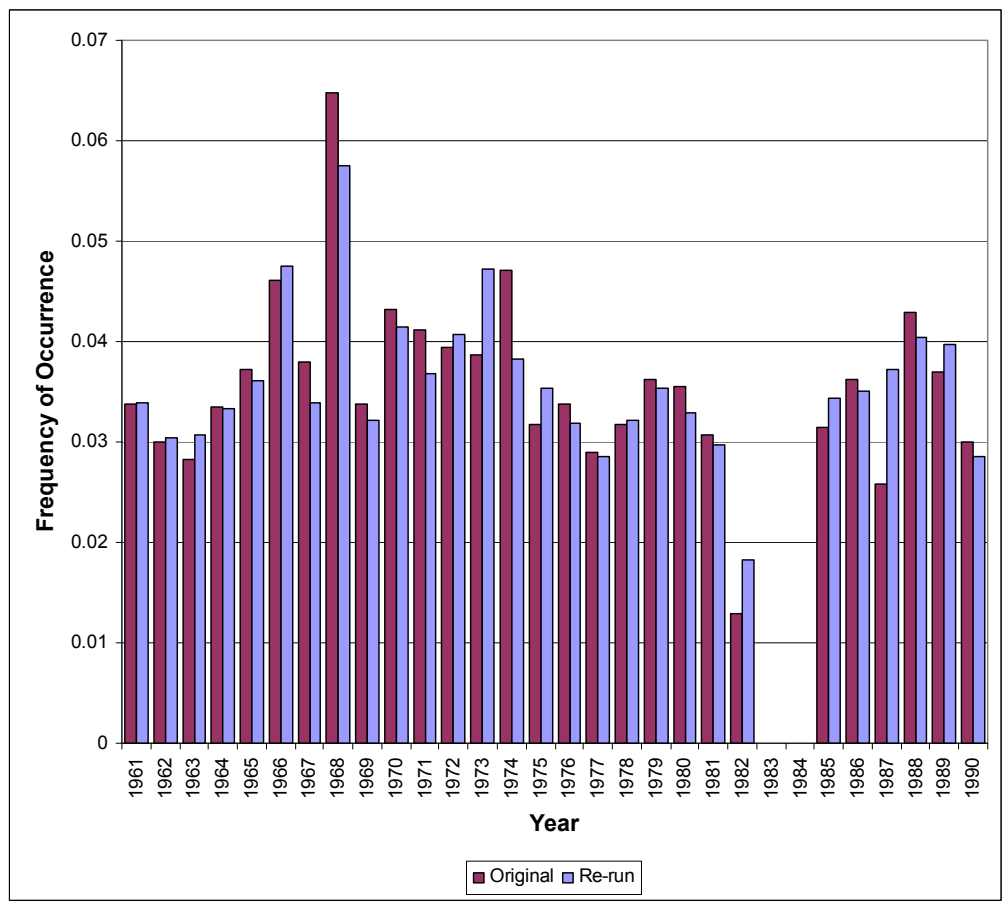

Figure 2-3. Year selection frequency comparison between original 1961-1990 and re-created 19611990 TMYs. 
Although some differences are apparent, the overall mix of the year selection closely correlates, which we feel validates the current TMY production software. Note that years corresponding to the eruptions of volcanoes El Chichón and Mount Pinatubo (1982-1984 and 1992-1994, respectively) are not represented among the selected years. These years are explicitly excluded by the TMY algorithm because the effects of increased aerosols on solar radiation for those years are considered atypical.

Figure 2-4 shows the year selection frequency for the 1976-2005 TMY. Note that the updated years 1991-2005 are under-represented in this data set (at about half the rate of 1976-1990). Given that both groups (1976-1990 and 1991-2005) have an equal 15-year span, further study is required to determine why the algorithm prefers data from the earlier years.

Figures 2-5 shows the year selection frequency for the TMYs derived from the 1991-2005 data sets. Note that, although the years 1999-2005 are proportioned similarly between these two data sets, 1998 is the least frequent year selected from years 1998-2005 in the former and the most frequent in the latter.

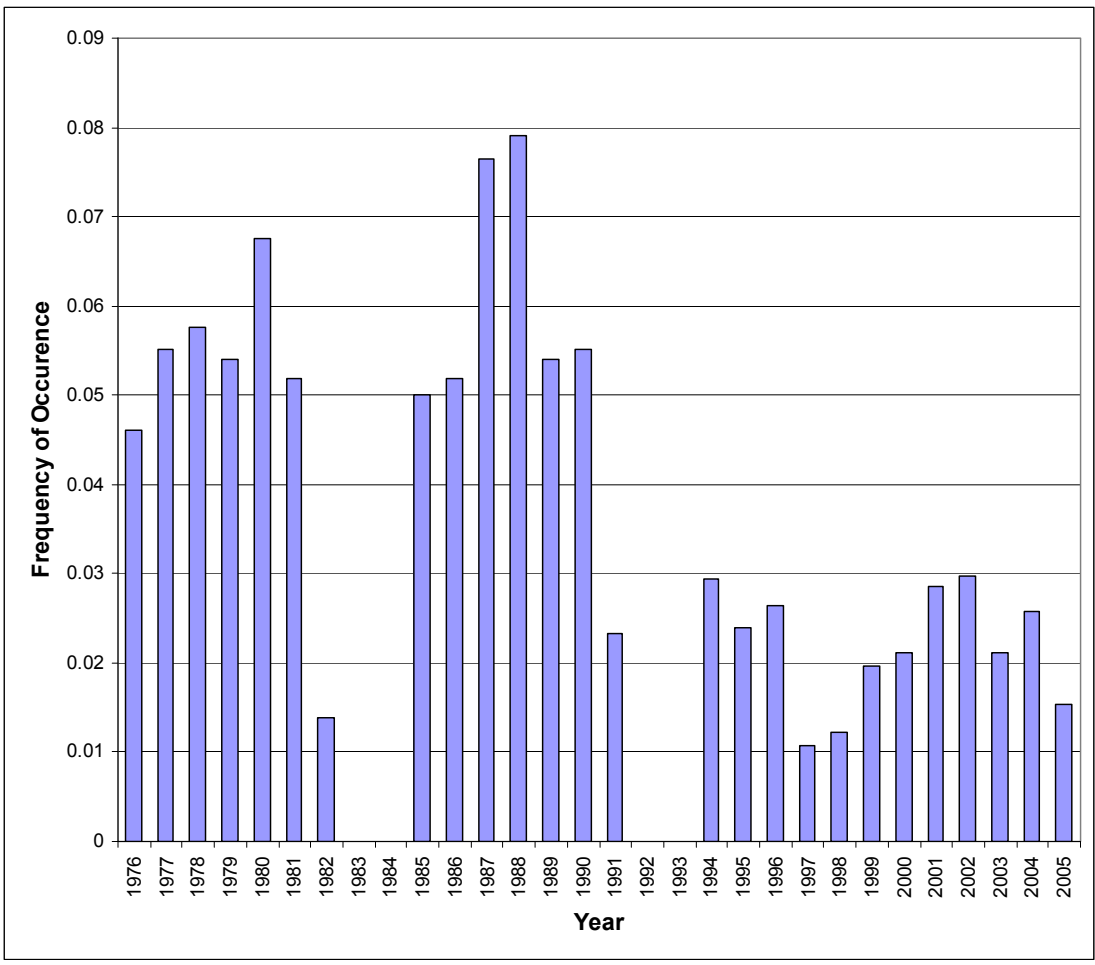

Figure 2-4. Year selection frequency for 30-year 1976-2005 TMY. 


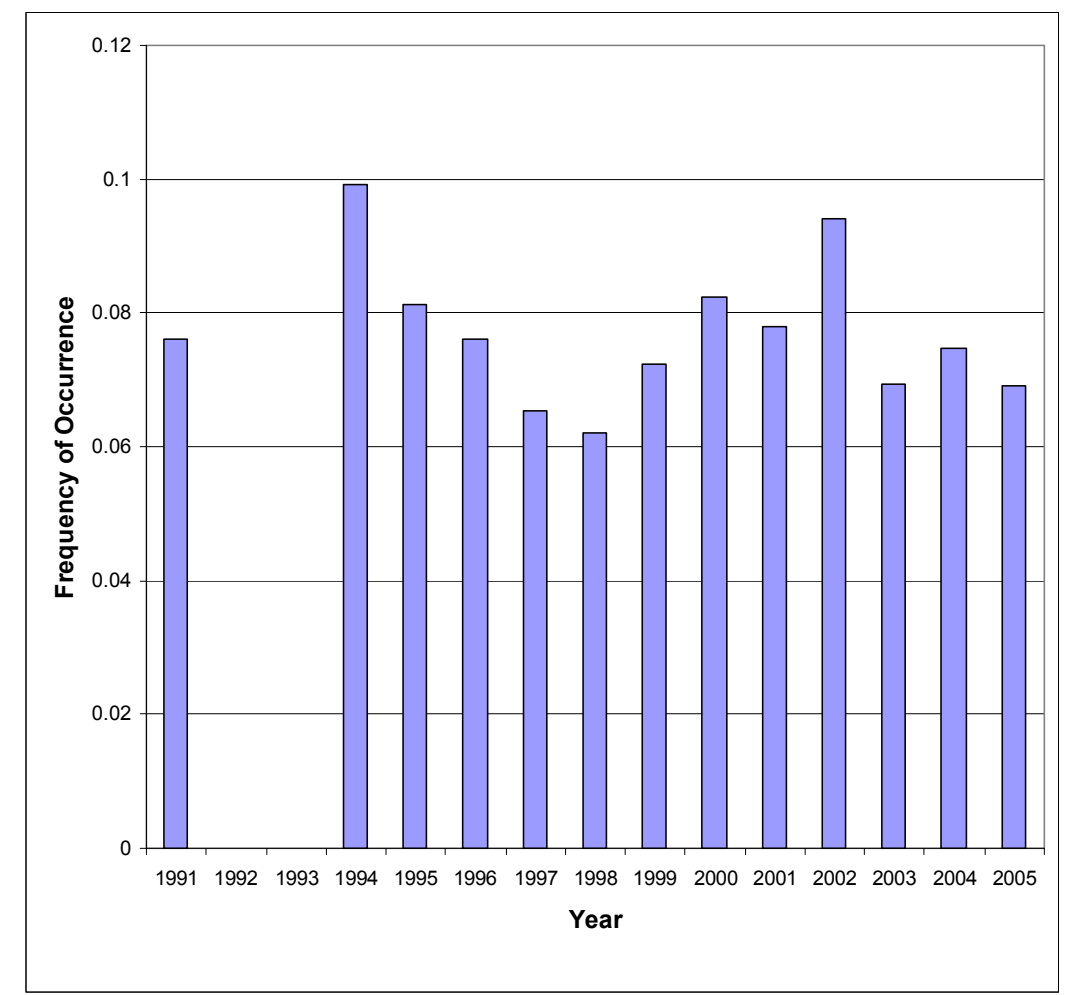

Figure 2-5. Year selection frequency for 15-year 1991-2005 TMY.

\subsection{Calculation of Illuminance Data}

To facilitate lighting and energy analysis of buildings, hourly values for global horizontal illuminance, direct normal illuminance, and diffuse horizontal illuminance in units of lux, and zenith luminance in units of $\mathrm{cd} / \mathrm{m}^{2}$ were added to the TMY3 data. These elements were calculated using luminous efficacy models developed by Perez et al. (1990). Inputs to the models are direct normal radiation, diffuse horizontal radiation, solar zenith angle, and dew point temperature.

\subsection{Assignment of Source and Uncertainty Flags}

With the exception of extraterrestrial horizontal and extraterrestrial direct radiation, each data value was assigned a source and uncertainty flags. The source flag indicates whether the data were measured, modeled, or missing, and the uncertainty flag provides an estimate of the uncertainty of the data. Source and uncertainty flags for extraterrestrial horizontal and extraterrestrial direct radiation are not provided because these elements were calculated using equations considered to give values without significant error for this application.

Usually, the source and uncertainty flags are the same as the ones in the NSRDB, from which the TMY files were derived. In the case of the TMY3 data files, the uncertainties are expressed as plus-minus percent rather than the coded uncertainty used in the TMY2 files. Uncertainty values apply to the data with respect to actual values at the time stamp, and not to how "typical" a particular hour is for a future month and day. The uncertainty values represent the plus or minus interval about the data value that contains the true value $95 \%$ of the time. 
The uncertainty assigned to modeled solar radiation data includes primarily the bias error in the model and, to a lesser extent, the random error component, which could be several times larger for partly cloudy skies (Wilcox, 2007b). For partly cloudy skies, an hour can be composed of large or small amounts of sunshine, depending on whether the sun is mostly free of the clouds or occluded by the clouds. Consequently, modeled hourly values may depart significantly from true values for partly cloudy skies. The uncertainty assigned to modeled solar radiation data represents the average uncertainty for a large number of model estimates (such as for a month). When averaging large data sets, random errors tend to cancel, leaving only the bias error.

Uncertainties for values of illuminance and luminance were determined by taking the root-sumsquare of the two main sources of error: (1) uncertainty of the solar radiation element (global horizontal, direct normal, or diffuse horizontal radiation) from which the illuminance or luminance element is derived, and (2) uncertainty of the model estimate. The uncertainty of the model estimates are based on the evaluation presented by Perez et al. (1990) for six test stations. To be conservative, the following model mean bias errors for the stations with the largest errors were used:

- $1.2 \%$ for global horizontal illuminance

- $1.6 \%$ for direct normal illuminance

- $2.3 \%$ for diffuse horizontal illuminance

- $1.2 \%$ for zenith luminance.

The uncertainty of the illuminance data value was then determined as the root-sum-square of the model uncertainty and solar radiation element uncertainty (for zenith luminance, the model value was root-sum-squared with the global radiation uncertainty).

The use of the bias error, instead of bias and random error, is consistent with the approach in the above paragraph concerning the assignment of uncertainty values to modeled solar radiation elements. Consequently, it also has the same implications: The assigned uncertainty is representative of the average uncertainty for a large number of model estimates (such as for a month)..

For meteorological elements, relative uncertainties from the NSRDB were used. These uncertainties do not portray a quantitative evaluation of the uncertainty of the meteorological elements, but rather give relative uncertainties based on the data and the manner in which they were derived (NSRDB-Vol. 1 1992).

The source and uncertainty flags for the solar radiation, illuminance, and meteorological elements are presented in Tables 1-4 through 1-6. 


\section{References}

ASHRAE (1993). 1993 ASHRAE Handbook: Fundamentals. Atlanta, GA: American Society of Heating, Refrigerating and Air-Conditioning Engineers, Inc.

ASHRAE - American Society of Heating, Refrigerating, and Air-Conditioning Engineers (2004). Sources of Uncertainty in the Calculation of the Design Weather Conditions in the ASHRAE Handbook of Fundamentals. Research Report RP-1171.

Finkelstein, J.M.; Schafer, R.E. (1971). “Improved Goodness-of-Fit Tests.” Biometrika, 58(3), pp. 641-645.

Hall, I.; Prairie, R.; Anderson, H.; Boes, E. (1978). Generation of Typical Meteorological Years for 26 SOLMET Stations. SAND78-1601. Albuquerque, NM: Sandia National Laboratories.

Marion, W., Urban, K., Users Manual for TMY2s-Typical Meteorological Years Derived from the 1961-1990 National Solar Radiation Data Base, NREL/TP-463-7668, Golden, CO: National Renewable Energy Laboratory, 1995.

NSRDB - Vol. 1 (1992). User's Manual - National Solar Radiation Data Base (1961-1990). Version 1.0. Golden, CO: National Renewable Energy Laboratory and Asheville, NC: National Climatic Data Center.

Perez, R.; Ineichen, P.; Seals, R.; Michalsky, J.; Stewart, R. (1990). "Modeling Daylight Availability and Irradiance Components from Direct and Global Irradiance." Solar Energy, 44(5), pp. 271-289.

Stoffel, T.; Nelson, D. (1993). Effects of the Mt. Pinatubo Volcanic Eruption on Solar Radiation Resources near Denver, Colorado - Some Preliminary Analyses. Burley, S. M.; Arden, M. E., eds. Solar '93: Proceedings of the 1993 Annual Conference of the American Solar Energy Society, 22-28 April 1993, Washington, DC. Boulder, CO: American Solar Energy Society pp. 489-494. Acc No. 13482.

Vignola, F., McDaniels, K. (1993) Value of long-term solar radiation data. Proceedings of the Solar '93 Conference, American Solar Energy Society. Boulder, CO: American Solar Energy Society (ASES).

Wilcox, S.; Anderberg, M.; George, R.; Marion, W.; Myers, D.; Renne, D.; Lott, N.; Whitehurst, T.; Beckman, W.; Gueymard, C.; Perez, R.; Stackhouse, P.; Vignola, F. (2007). Completing Production of the Updated National Solar Radiation Database for the United States. CampbellHowe, R., ed. Proceedings of the Solar 2007 Conference, 8-12 July 2007, Cleveland, Ohio (CDROM). Including Proceedings of 36th ASES Annual Conference, Proceedings of 32nd National Passive Solar Conference, and Proceedings of the 2nd Renewable Energy Policy and Marketing Conference. Boulder, CO: American Solar Energy Society (ASES) 8 pp.; NREL Report No. CP581-41511.

Wilcox, S. (2007). National Solar Radiation Database 1991-2005 Update: User's Manual. 472 pp.; NREL Report No. TP-581-41364. 
Wilcox, S.; Marion, W. (2008). Development of an Updated Typical Meteorological Year Data Set for the United States. Campbell-Howe, R., ed. Proceedings of the Solar 2008 Conference, 3-8 May 2008, San Diego, CA (CD-ROM. Boulder, CO: American Solar Energy Society (ASES). 


\section{Appendix A - TMY3 Stations}

Table A-1 lists all stations in the TMY3 data set, ordered by state and then site name. The table columns are described below:

- USAF - The United States Air Force code used by the National Climatic Data Center for station identification (identical to the station identification numbers in the 1991-2005 NSRDB Update)

- Station Name - The measurement station name. These names are identical to those used in the 1991-2005 NSRDB update. In some cases, the name of a solar measurement site is included in the station name in square brackets. This naming convention is retained for conformity with the NSRDB update. (No measured solar data from the NSRDB update are used in the TMY3 data set.)

- State - The two-character U.S. Postal Service state/possession code including Puerto Rico (PR) and Guam (GU)

- Latitude - Site latitude (decimal degrees)

- Longitude - Site longitude (decimal degrees)

- Time Zone - Number of hours from Greenwich time (negative west)

- Elevation - Elevation of the station (meters)

- NSRDB Class - The station classification used by the 1991-2005 NSRDB Update (see Section 1.5).

- Pool Years - The minimum number of years from which TMY candidate months were pulled (see Section 1.5).

Table A-1. TMY3 station information

\begin{tabular}{|c|l|c|c|c|c|c|c|c|}
\hline USAF & \multicolumn{1}{|c|}{ Station Name } & State & $\begin{array}{c}\text { Lati- } \\
\text { tude }\end{array}$ & $\begin{array}{c}\text { Longi- } \\
\text { tude }\end{array}$ & $\begin{array}{c}\text { Time } \\
\text { Zone }\end{array}$ & $\begin{array}{c}\text { Eleva- } \\
\text { tion }\end{array}$ & $\begin{array}{c}\text { NSRDB } \\
\text { Class }\end{array}$ & $\begin{array}{c}\text { Pool } \\
\text { Years }\end{array}$ \\
\hline 704540 & ADAK NAS & AK & 51.883 & -176.650 & -10 & 5 & III & 10 \\
\hline 701718 & AMBLER & AK & 67.100 & -157.850 & -9 & 88 & II & 12 \\
\hline 701625 & ANAKTUVUK PASS & AK & 68.133 & -151.733 & -9 & 657 & III & 11 \\
\hline 702730 & ANCHORAGE INTL AP & AK & 61.183 & -150.000 & -9 & 35 & II & 24 \\
\hline 702735 & ANCHORAGE MERRILL & AK & 61.217 & -149.850 & -9 & 42 & II & 12 \\
\hline 702720 & AIELD & AKCHORAGE/ELMENDORF & 61.250 & -149.800 & -9 & 59 & II & 12 \\
\hline 702320 & ANIAK AIRPORT & AK & 61.583 & -159.533 & -9 & 26 & III & 11 \\
\hline 703980 & ANNETTE ISLAND AP & AK & 55.050 & -131.567 & -9 & 33 & II & 24 \\
\hline 702075 & ANVIK & AK & 62.650 & -160.183 & -9 & 99 & III & 10 \\
\hline 700260 & BARROW W POST-W & AK & 71.320 & -156.620 & -9 & 10 & II & 24 \\
\hline 702190 & BOGERS ARPT [NSA - ARM] & AK & 60.783 & -161.833 & -9 & 38 & II & 24 \\
\hline 701740 & BETTLES FIELD & AK & 66.917 & -151.517 & -9 & 196 & II & 24 \\
\hline 702670 & BIG DELTA ALLEN AAF & AK & 64.000 & -145.717 & -9 & 386 & II & 24 \\
\hline 702986 & BIG RIVER LAKE & AK & 60.817 & -152.300 & -9 & 12 & II & 12 \\
\hline 702746 & BIRCHWOOD & AK & 61.417 & -149.517 & -9 & 30 & III & 11 \\
\hline 702606 & CHULITNA & AK & 62.883 & -149.833 & -9 & 381 & II & 12 \\
\hline 703160 & COLD BAY ARPT & AK & 55.200 & -162.717 & -9 & 29 & II & 24 \\
\hline 702960 & CORDOVA & AK & 60.500 & -145.500 & -9 & 12 & II & 12 \\
\hline
\end{tabular}




\begin{tabular}{|c|c|c|c|c|c|c|c|c|}
\hline USAF & Station Name & State & $\begin{array}{l}\text { Lati- } \\
\text { tude }\end{array}$ & $\begin{array}{l}\text { Longi- } \\
\text { tude }\end{array}$ & $\begin{array}{l}\text { Time } \\
\text { Zone }\end{array}$ & $\begin{array}{c}\text { Eleva- } \\
\text { tion }\end{array}$ & $\begin{array}{l}\text { NSRDB } \\
\text { Class }\end{array}$ & $\begin{array}{l}\text { Pool } \\
\text { Years }\end{array}$ \\
\hline 700637 & DEADHORSE & AK & 70.200 & -148.483 & -9 & 23 & II & 12 \\
\hline 703210 & DILLINGHAM (AMOS) & AK & 59.050 & -158.517 & -9 & 29 & II & 12 \\
\hline 704890 & DUTCH HARBOR & AK & 53.900 & -166.550 & -9 & 4 & II & 12 \\
\hline 702084 & EMMONAK & AK & 62.783 & -164.500 & -9 & 4 & II & 12 \\
\hline 702610 & FAIRBANKS INTL ARPT & AK & 64.817 & -147.850 & -9 & 133 & II & 24 \\
\hline 702650 & FAIRBANKS/EIELSON A & AK & 64.650 & -147.100 & -9 & 167 & II & 12 \\
\hline 701940 & FORT YUKON & AK & 66.567 & -145.267 & -9 & 136 & III & 10 \\
\hline 702040 & GAMBELL & AK & 63.783 & -171.750 & -9 & 8 & III & 10 \\
\hline 702710 & $\begin{array}{l}\text { GULKANA INTERMEDIATE } \\
\text { FIELD }\end{array}$ & AK & 62.150 & -145.450 & -9 & 478 & II & 24 \\
\hline 703670 & GUSTAVUS & AK & 58.417 & -135.700 & -9 & 12 & II & 12 \\
\hline 702495 & HAYES RIVER & AK & 61.983 & -152.083 & -9 & 305 & II & 12 \\
\hline 702647 & HEALY RIVER AIRPORT & AK & 63.883 & -149.017 & -9 & 396 & II & 12 \\
\hline 703410 & HOMER ARPT & AK & 59.650 & -151.483 & -9 & 27 & II & 12 \\
\hline 702607 & $\mathrm{HOONAH}$ & AK & 58.083 & -135.450 & -9 & 6 & II & 12 \\
\hline 702186 & HOOPER BAY & AK & 61.517 & -166.150 & -9 & 6 & II & 12 \\
\hline 702225 & HUSLIA & AK & 65.700 & -156.383 & -9 & 55 & III & 10 \\
\hline 703884 & HYDABURG SEAPLANE & AK & 55.200 & -132.833 & -9 & 0 & III & 11 \\
\hline 703400 & ILIAMNA ARPT & $\mathrm{AK}$ & 59.750 & -154.917 & -9 & 57 & II & 12 \\
\hline 703810 & JUNEAU INT'L ARPT & AK & 58.350 & -134.583 & -9 & 4 & II & 12 \\
\hline 703855 & KAKE SEAPLANE BASE & AK & 56.967 & -133.950 & -9 & 0 & II & 12 \\
\hline 702590 & KENAI MUNICIPAL AP & AK & 60.583 & -151.233 & -9 & 26 & II & 12 \\
\hline 703950 & KETCHIKAN INTL AP & AK & 55.367 & -131.717 & -9 & 23 & II & 12 \\
\hline 703260 & KING SALMON ARPT & $\mathrm{AK}$ & 58.683 & -156.650 & -9 & 15 & II & 24 \\
\hline 703500 & KODIAK AIRPORT & AK & 57.750 & -152.500 & -9 & 5 & II & 24 \\
\hline 701330 & $\begin{array}{l}\text { KOTZEBUE RALPH WEIN } \\
\text { MEMORIAL }\end{array}$ & AK & 66.883 & -162.600 & -9 & 3 & II & 24 \\
\hline 702725 & LAKE HOOD SEAPLANE & $\mathrm{AK}$ & 61.183 & -149.967 & -9 & 22 & III & 12 \\
\hline 702310 & MCGRATH ARPT & AK & 62.950 & -155.600 & -9 & 105 & II & 24 \\
\hline 702185 & MEKORYUK & AK & 60.367 & -166.267 & -9 & 15 & II & 12 \\
\hline 703430 & MIDDLETON ISLAND AUT & AK & 59.467 & -146.317 & -9 & 14 & II & 12 \\
\hline 702460 & MINCHUMINA & AK & 63.883 & -152.283 & -9 & 213 & II & 12 \\
\hline 702600 & NENANA MUNICIPAL AP & AK & 64.550 & -149.100 & -9 & 109 & II & 12 \\
\hline 702000 & NOME MUNICIPAL ARPT & AK & 64.517 & -165.450 & -9 & 4 & II & 24 \\
\hline 702910 & NORTHWAY AIRPORT & AK & 62.967 & -141.933 & -9 & 522 & II & 12 \\
\hline 702740 & PALMER MUNICIPAL & AK & 61.600 & -149.083 & -9 & 71 & II & 12 \\
\hline 703860 & PETERSBURG & AK & 56.800 & -132.950 & -9 & 33 & II & 12 \\
\hline 701043 & POINT HOPE (AWOS) & $\mathrm{AK}$ & 68.350 & -166.800 & -9 & 4 & II & 12 \\
\hline 703330 & PORT HEIDEN & AK & 56.950 & -158.617 & -9 & 29 & II & 12 \\
\hline 702005 & SAINT MARY S (AWOS) & AK & 62.067 & -163.300 & -9 & 95 & II & 12 \\
\hline 703165 & SAND POINT & AK & 55.317 & -160.517 & -9 & 7 & II & 12 \\
\hline 702035 & SAVOONGA & $\mathrm{AK}$ & 63.683 & -170.500 & -9 & 17 & III & 12 \\
\hline 700197 & SELAWIK & AK & 66.600 & -160.000 & -9 & 8 & III & 11 \\
\hline 702770 & SEWARD & AK & 60.117 & -149.450 & -9 & 18 & II & 12 \\
\hline 704140 & SHEMYA AFB & AK & 52.717 & 174.117 & -10 & 31 & II & 12 \\
\hline 701195 & SHISHMAREF (AWOS) & AK & 66.267 & -166.050 & -9 & 2 & II & 12 \\
\hline 703710 & SITKA JAPONSKI AP & AK & 57.050 & -135.367 & -9 & 4 & II & 12 \\
\hline
\end{tabular}




\begin{tabular}{|c|c|c|c|c|c|c|c|c|}
\hline USAF & Station Name & State & $\begin{array}{l}\text { Lati- } \\
\text { tude }\end{array}$ & $\begin{array}{l}\text { Longi- } \\
\text { tude }\end{array}$ & $\begin{array}{l}\text { Time } \\
\text { Zone }\end{array}$ & $\begin{array}{c}\text { Eleva- } \\
\text { tion }\end{array}$ & $\begin{array}{l}\text { NSRDB } \\
\text { Class }\end{array}$ & $\begin{array}{l}\text { Pool } \\
\text { Years }\end{array}$ \\
\hline 703620 & SKAGWAY AIRPORT & AK & 59.467 & -135.300 & -9 & 9 & II & 12 \\
\hline 703407 & SLEETMUTE & AK & 61.717 & -157.150 & -9 & 54 & III & 11 \\
\hline 702595 & SOLDOTNA & AK & 60.467 & -151.033 & -9 & 34 & III & 12 \\
\hline 703080 & ST PAUL ISLAND ARPT & AK & 57.167 & -170.217 & -9 & 7 & II & 24 \\
\hline 702510 & TALKEETNA STATE ARPT & $\mathrm{AK}$ & 62.317 & -150.100 & -9 & 105 & II & 24 \\
\hline 701780 & $\begin{array}{l}\text { TANANA RALPH M } \\
\text { CALHOUN MEM AP }\end{array}$ & AK & 65.167 & -152.100 & -9 & 71 & II & 12 \\
\hline 703606 & TOGIAC VILLAGE AWOS & $\mathrm{AK}$ & 59.050 & -160.400 & -9 & 6 & II & 12 \\
\hline 702070 & UNALAKLEET FIELD & AK & 63.883 & -160.800 & -9 & 5 & III & 11 \\
\hline 702756 & VALDEZ PIONEER FIEL & AK & 61.133 & -146.267 & -9 & 38 & II & 12 \\
\hline 702750 & VALDEZ WSO & AK & 61.133 & -146.350 & -9 & 7 & II & 12 \\
\hline 702757 & WHITTIER & AK & 60.767 & -148.683 & -9 & 9 & II & 12 \\
\hline 703870 & WRANGELL & AK & 56.483 & -132.367 & -9 & 13 & II & 12 \\
\hline 703610 & YAKUTAT STATE ARPT & AK & 59.517 & -139.633 & -9 & 8 & II & 24 \\
\hline 722287 & $\begin{array}{l}\text { ANNISTON METROPOLITAN } \\
\text { AP }\end{array}$ & $\mathrm{AL}$ & 33.583 & -85.850 & -6 & 186 & II & 12 \\
\hline 722284 & AUBURN-OPELIKA APT & $\mathrm{AL}$ & 32.616 & -85.433 & -6 & 236 & III & 12 \\
\hline 722280 & $\begin{array}{l}\text { BIRMINGHAM MUNICIPAL } \\
\text { AP }\end{array}$ & $\mathrm{AL}$ & 33.567 & -86.750 & -6 & 189 & 1 & 24 \\
\hline 722269 & $\begin{array}{l}\text { CAIRNS FIELD FORT } \\
\text { RUCKER }\end{array}$ & $\mathrm{AL}$ & 31.267 & -85.717 & -6 & 91 & II & 12 \\
\hline 722268 & DOTHAN MUNICIPAL AP & $\mathrm{AL}$ & 31.233 & -85.433 & -6 & 98 & II & 12 \\
\hline 722285 & GADSEN MUNI (AWOS) & $\mathrm{AL}$ & 33.967 & -86.083 & -6 & 173 & III & 12 \\
\hline 723230 & $\begin{array}{l}\text { HUNTSVILLE INTL/JONES } \\
\text { FIELD }\end{array}$ & $\mathrm{AL}$ & 34.650 & -86.783 & -6 & 190 & 1 & 24 \\
\hline 722265 & MAXWELL AFB & $\mathrm{AL}$ & 32.383 & -86.350 & -6 & 53 & II & 12 \\
\hline 722235 & MOBILE DOWNTOWN AP & $\mathrm{AL}$ & 30.633 & -88.067 & -6 & 8 & II & 12 \\
\hline 722230 & MOBILE REGIONAL AP & $\mathrm{AL}$ & 30.683 & -88.250 & -6 & 66 & I & 24 \\
\hline 722260 & $\begin{array}{l}\text { MONTGOMERY DANNELLY } \\
\text { FIELD }\end{array}$ & $\mathrm{AL}$ & 32.300 & -86.400 & -6 & 62 & I & 24 \\
\hline 723235 & $\begin{array}{l}\text { MUSCLE SHOALS } \\
\text { REGIONAL AP }\end{array}$ & $A L$ & 34.750 & -87.600 & -6 & 165 & II & 12 \\
\hline 722267 & TROY AF & $\mathrm{AL}$ & 31.867 & -86.017 & -6 & 120 & II & 12 \\
\hline 722286 & $\begin{array}{l}\text { TUSCALOOSA MUNICIPAL } \\
\text { AP }\end{array}$ & $A L$ & 33.217 & -87.617 & -6 & 51 & II & 12 \\
\hline 723448 & BATESVILLE (AWOS) & AR & 35.733 & -91.650 & -6 & 141 & III & 12 \\
\hline 723444 & BENTONVILLE (AWOS) & AR & 36.350 & -94.217 & -6 & 395 & III & 12 \\
\hline 723419 & $\begin{array}{l}\text { EL DORADO GOODWIN } \\
\text { FIELD }\end{array}$ & AR & 33.217 & -92.817 & -6 & 77 & II & 12 \\
\hline 723445 & $\begin{array}{l}\text { FAYETTEVILLE DRAKE } \\
\text { FIELD }\end{array}$ & AR & 36.000 & -94.167 & -6 & 381 & II & 12 \\
\hline 723447 & FLIPPIN (AWOS) & AR & 36.300 & -92.467 & -6 & 350 & III & 12 \\
\hline 723440 & FORT SMITH REGIONAL AP & AR & 35.333 & -94.367 & -6 & 137 & II & 24 \\
\hline 723446 & HARRISON FAA AP & AR & 36.267 & -93.150 & -6 & 419 & II & 12 \\
\hline 723407 & JONESBORO MUNI & AR & 35.833 & -90.650 & -6 & 82 & II & 12 \\
\hline 723403 & LITTLE ROCK ADAMS FIELD & AR & 34.750 & -92.233 & -6 & 78 & I & 24 \\
\hline 723405 & LITTLE ROCK AFB & AR & 34.917 & -92.150 & -6 & 103 & II & 12 \\
\hline 723415 & MEMORIAL FLD & AR & 34.467 & -93.100 & -6 & 169 & II & 12 \\
\hline 723417 & PINE BLUFF FAA AP & AR & 34.167 & -91.933 & -6 & 63 & II & 12 \\
\hline
\end{tabular}




\begin{tabular}{|c|c|c|c|c|c|c|c|c|}
\hline USAF & Station Name & State & $\begin{array}{l}\text { Lati- } \\
\text { tude }\end{array}$ & $\begin{array}{l}\text { Longi- } \\
\text { tude }\end{array}$ & $\begin{array}{l}\text { Time } \\
\text { Zone }\end{array}$ & $\begin{array}{c}\text { Eleva- } \\
\text { tion }\end{array}$ & $\begin{array}{l}\text { NSRDB } \\
\text { Class }\end{array}$ & $\begin{array}{l}\text { Pool } \\
\text { Years }\end{array}$ \\
\hline 723449 & ROGERS (AWOS) & AR & 36.367 & -94.100 & -6 & 415 & III & 12 \\
\hline 723443 & SILOAM SPRING(AWOS) & AR & 36.183 & -94.483 & -6 & 364 & III & 12 \\
\hline 723434 & SPRINGDALE MUNI & AR & 36.183 & -94.117 & -6 & 412 & III & 10 \\
\hline 723416 & STUTTGART (AWOS) & AR & 34.600 & -91.567 & -6 & 68 & II & 12 \\
\hline 723418 & TEXARKANA WEBB FIELD & AR & 33.450 & -94.000 & -6 & 110 & II & 12 \\
\hline 723406 & WALNUT RIDGE (AWOS) & AR & 36.133 & -90.917 & -6 & 83 & II & 12 \\
\hline 722748 & CASA GRANDA (AWOS) & $A Z$ & 32.950 & -111.767 & -7 & 446 & III & 12 \\
\hline 722745 & DAVIS MONTHAN AFB & $A Z$ & 32.167 & -110.883 & -7 & 809 & II & 12 \\
\hline 722784 & DEER VALLEY/PHOENIX & $A Z$ & 33.683 & -112.083 & -7 & 450 & II & 12 \\
\hline 722735 & $\begin{array}{l}\text { DOUGLAS BISBEE- } \\
\text { DOUGLAS INTL A }\end{array}$ & $A Z$ & 31.467 & -109.600 & -7 & 1249 & II & 12 \\
\hline 723755 & FLAGSTAFF PULLIAM ARPT & $A Z$ & 35.133 & -111.667 & -7 & 2132 & III & 22 \\
\hline 723783 & GRAND CANYON NATL P & $A Z$ & 35.950 & -112.150 & -7 & 2065 & II & 12 \\
\hline 723700 & KINGMAN (AMOS) & $A Z$ & 35.267 & -113.950 & -7 & 1033 & II & 12 \\
\hline 722785 & LUKE AFB & $A Z$ & 33.550 & -112.367 & -7 & 331 & II & 12 \\
\hline 723710 & PAGE MUNI (AMOS) & $A Z$ & 36.933 & -111.450 & -7 & 1304 & III & 10 \\
\hline 722780 & $\begin{array}{l}\text { PHOENIX SKY HARBOR } \\
\text { INTL AP }\end{array}$ & $A Z$ & 33.450 & -111.983 & -7 & 337 & 1 & 24 \\
\hline 723723 & PRESCOTT LOVE FIELD & $A Z$ & 34.650 & -112.417 & -7 & 1537 & I & 24 \\
\hline 722747 & SAFFORD (AMOS) & $A Z$ & 32.817 & -109.683 & -7 & 950 & III & 10 \\
\hline 722789 & SCOTTSDALE MUNI & $A Z$ & 33.617 & -111.917 & -7 & 460 & II & 12 \\
\hline 723747 & SHOW LOW MUNICIPAL & $A Z$ & 34.267 & -110.000 & -7 & 1954 & II & 12 \\
\hline 722740 & $\begin{array}{l}\text { TUCSON INTERNATIONAL } \\
\text { AP }\end{array}$ & $A Z$ & 32.133 & -110.950 & -7 & 777 & 1 & 24 \\
\hline 723740 & WINSLOW MUNICIPAL AP & $A Z$ & 35.033 & -110.717 & -7 & 1490 & II & 12 \\
\hline 722800 & YUMA INTL ARPT & $A Z$ & 32.667 & -114.600 & -7 & 63 & II & 12 \\
\hline 699604 & YUMA MCAS & $A Z$ & 32.650 & -114.617 & -7 & 65 & II & 12 \\
\hline 725958 & ALTURAS & $\mathrm{CA}$ & 41.500 & -120.533 & -8 & 1341 & II & 12 \\
\hline 725945 & ARCATA AIRPORT & $\mathrm{CA}$ & 40.983 & -124.100 & -8 & 62 & $\mathrm{I}$ & 24 \\
\hline 723840 & $\begin{array}{l}\text { BAKERSFIELD MEADOWS } \\
\text { FIELD }\end{array}$ & CA & 35.433 & -119.050 & -8 & 149 & I & 24 \\
\hline 724837 & BEALE AFB & $\mathrm{CA}$ & 39.133 & -121.433 & -8 & 38 & II & 12 \\
\hline 724800 & BISHOP AIRPORT & $\mathrm{CA}$ & 37.367 & -118.350 & -8 & 1250 & II & 12 \\
\hline 725845 & BLUE CANYON AP & $\mathrm{CA}$ & 39.300 & -120.717 & -8 & 1609 & II & 12 \\
\hline 747188 & $\begin{array}{l}\text { BLYTHE RIVERSIDE CO } \\
\text { ARPT }\end{array}$ & CA & 33.617 & -114.717 & -8 & 119 & II & 12 \\
\hline 722880 & $\begin{array}{l}\text { BURBANK-GLENDALE- } \\
\text { PASSADENA AP }\end{array}$ & CA & 34.200 & -118.350 & -8 & 226 & II & 12 \\
\hline 723926 & CAMARILLO (AWOS) & $\mathrm{CA}$ & 34.217 & -119.083 & -8 & 23 & III & 12 \\
\hline 722926 & CAMP PENDLETON MCAS & $\mathrm{CA}$ & 33.300 & -117.350 & -8 & 23 & II & 12 \\
\hline 722927 & CARLSBAD/PALOMAR & $\mathrm{CA}$ & 33.133 & -117.283 & -8 & 100 & II & 12 \\
\hline 746120 & CHINA LAKE NAF & $\mathrm{CA}$ & 35.683 & -117.683 & -8 & 677 & II & 12 \\
\hline 722899 & CHINO AIRPORT & $\mathrm{CA}$ & 33.967 & -117.633 & -8 & 198 & III & 11 \\
\hline 722904 & $\begin{array}{l}\text { CHULA VISTA BROWN } \\
\text { FIELD NAAS }\end{array}$ & CA & 32.583 & -116.983 & -8 & 159 & II & 12 \\
\hline 724936 & $\begin{array}{l}\text { CONCORD CONCORD- } \\
\text { BUCHANAN FIEL }\end{array}$ & CA & 38.000 & -122.050 & -8 & 7 & II & 12 \\
\hline 725946 & CRESCENT CITY FAA AI & $\mathrm{CA}$ & 41.783 & -124.233 & -8 & 17 & II & 12 \\
\hline
\end{tabular}




\begin{tabular}{|c|c|c|c|c|c|c|c|c|}
\hline USAF & Station Name & State & $\begin{array}{l}\text { Lati- } \\
\text { tude }\end{array}$ & $\begin{array}{l}\text { Longi- } \\
\text { tude }\end{array}$ & $\begin{array}{l}\text { Time } \\
\text { Zone }\end{array}$ & $\begin{array}{c}\text { Eleva- } \\
\text { tion }\end{array}$ & $\begin{array}{l}\text { NSRDB } \\
\text { Class }\end{array}$ & $\begin{array}{l}\text { Pool } \\
\text { Years }\end{array}$ \\
\hline 723815 & $\begin{array}{l}\text { DAGGETT BARSTOW- } \\
\text { DAGGETT AP }\end{array}$ & CA & 34.850 & -116.800 & -8 & 586 & 1 & 24 \\
\hline 723810 & EDWARDS AFB & CA & 34.900 & -117.867 & -8 & 706 & II & 12 \\
\hline 723890 & FRESNO YOSEMITE INTL AP & $\mathrm{CA}$ & 36.783 & -119.717 & -8 & 102 & I & 24 \\
\hline 722976 & FULLERTON MUNICIPAL & $\mathrm{CA}$ & 33.867 & -117.983 & -8 & 29 & II & 12 \\
\hline 724935 & HAYWARD AIR TERM & $\mathrm{CA}$ & 37.667 & -122.117 & -8 & 14 & II & 12 \\
\hline 747185 & IMPERIAL & $\mathrm{CA}$ & 32.833 & -115.583 & -8 & -17 & II & 12 \\
\hline 722956 & JACK NORTHROP FLD H & $\mathrm{CA}$ & 33.917 & -118.333 & -8 & 21 & II & 12 \\
\hline 723816 & $\begin{array}{l}\text { LANCASTER GEN WM FOX } \\
\text { FIELD }\end{array}$ & CA & 34.733 & -118.217 & -8 & 713 & II & 12 \\
\hline 747020 & LEMOORE REEVES NAS & CA & 36.333 & -119.950 & -8 & 73 & II & 12 \\
\hline 724927 & LIVERMORE MUNICIPAL & CA & 37.700 & -121.817 & -8 & 121 & II & 12 \\
\hline 722895 & LOMPOC (AWOS) & $\mathrm{CA}$ & 34.667 & -120.467 & -8 & 27 & III & 12 \\
\hline 722970 & $\begin{array}{l}\text { LONG BEACH DAUGHERTY } \\
\text { FLD }\end{array}$ & CA & 33.833 & -118.167 & -8 & 8 & 1 & 24 \\
\hline 722950 & LOS ANGELES INTL ARPT & $\mathrm{CA}$ & 33.933 & -118.400 & -8 & 30 & 1 & 24 \\
\hline 722860 & MARCH AFB & CA & 33.900 & -117.250 & -8 & 462 & II & 12 \\
\hline 724815 & MERCED/MACREADY FLD & $\mathrm{CA}$ & 37.283 & -120.517 & -8 & 47 & II & 12 \\
\hline 724926 & $\begin{array}{l}\text { MODESTO CITY-COUNTY } \\
\text { AP }\end{array}$ & CA & 37.633 & -120.950 & -8 & 30 & II & 12 \\
\hline 725955 & $\begin{array}{l}\text { MONTAGUE SISKIYOU } \\
\text { COUNTY AP }\end{array}$ & CA & 41.783 & -122.467 & -8 & 803 & II & 12 \\
\hline 724915 & MONTEREY NAF & CA & 36.600 & -121.867 & -8 & 50 & II & 12 \\
\hline 745090 & $\begin{array}{l}\text { MOUNTAIN VIEW MOFFETT } \\
\text { FLD NAS }\end{array}$ & CA & 37.400 & -122.050 & -8 & 12 & III & 10 \\
\hline 724955 & NAPA CO. AIRPORT & $\mathrm{CA}$ & 38.217 & -122.283 & -8 & 10 & II & 12 \\
\hline 723805 & NEEDLES AIRPORT & $\mathrm{CA}$ & 34.767 & -114.617 & -8 & 279 & II & 12 \\
\hline 724930 & $\begin{array}{l}\text { OAKLAND METROPOLITAN } \\
\text { ARPT }\end{array}$ & CA & 37.717 & -122.217 & -8 & 2 & II & 12 \\
\hline 723927 & OXNARD AIRPORT & CA & 34.200 & -119.200 & -8 & 11 & II & 12 \\
\hline 722868 & PALM SPRINGS INTL & $\mathrm{CA}$ & 33.833 & -116.500 & -8 & 145 & II & 12 \\
\hline 747187 & $\begin{array}{l}\text { PALM SPRINGS THERMAL } \\
\text { AP }\end{array}$ & CA & 33.633 & -116.167 & -8 & -34 & II & 12 \\
\hline 723820 & PALMDALE AIRPORT & CA & 34.633 & -118.083 & -8 & 769 & II & 12 \\
\hline 723965 & $\begin{array}{l}\text { PASO ROBLES MUNICIPAL } \\
\text { ARPT }\end{array}$ & CA & 35.667 & -120.633 & -8 & 244 & II & 12 \\
\hline 723910 & POINT MUGU NF & $\mathrm{CA}$ & 34.117 & -119.117 & -8 & 3 & II & 12 \\
\hline 723895 & PORTERVILLE (AWOS) & $\mathrm{CA}$ & 36.033 & -119.067 & -8 & 135 & III & 12 \\
\hline 725910 & $\begin{array}{l}\text { RED BLUFF MUNICIPAL } \\
\text { ARPT }\end{array}$ & $\mathrm{CA}$ & 40.150 & -122.250 & -8 & 106 & II & 12 \\
\hline 725920 & REDDING MUNICIPAL ARPT & CA & 40.517 & -122.317 & -8 & 153 & I & 12 \\
\hline 722869 & RIVERSIDE MUNI & CA & 33.950 & -117.450 & -8 & 256 & II & 12 \\
\hline 724830 & $\begin{array}{l}\text { SACRAMENTO EXECUTIVE } \\
\text { ARPT }\end{array}$ & CA & 38.500 & -121.500 & -8 & 5 & 1 & 24 \\
\hline 724839 & $\begin{array}{l}\text { SACRAMENTO } \\
\text { METROPOLITAN AP }\end{array}$ & CA & 38.700 & -121.583 & -8 & 7 & II & 12 \\
\hline 724917 & SALINAS MUNICIPAL AP & $\mathrm{CA}$ & 36.667 & -121.600 & -8 & 21 & II & 12 \\
\hline 722900 & $\begin{array}{l}\text { SAN DIEGO LINDBERGH } \\
\text { FIELD }\end{array}$ & CA & 32.733 & -117.167 & -8 & 4 & 1 & 24 \\
\hline 722930 & SAN DIEGO MIRAMAR NAS & $\mathrm{CA}$ & 32.867 & -117.133 & -8 & 140 & II & 12 \\
\hline
\end{tabular}




\begin{tabular}{|c|c|c|c|c|c|c|c|c|}
\hline USAF & Station Name & State & $\begin{array}{l}\text { Lati- } \\
\text { tude }\end{array}$ & $\begin{array}{l}\text { Longi- } \\
\text { tude }\end{array}$ & $\begin{array}{l}\text { Time } \\
\text { Zone }\end{array}$ & $\begin{array}{c}\text { Eleva- } \\
\text { tion }\end{array}$ & $\begin{array}{l}\text { NSRDB } \\
\text { Class }\end{array}$ & $\begin{array}{l}\text { Pool } \\
\text { Years }\end{array}$ \\
\hline 722906 & $\begin{array}{l}\text { SAN DIEGO NORTH ISLAND } \\
\text { NAS }\end{array}$ & CA & 32.700 & -117.200 & -8 & 15 & II & 12 \\
\hline 722903 & SAN DIEGO/MONTGOMER & $\mathrm{CA}$ & 32.817 & -117.133 & -8 & 129 & II & 12 \\
\hline 724940 & SAN FRANCISCO INTL AP & $\mathrm{CA}$ & 37.617 & -122.400 & -8 & 2 & $\mathrm{I}$ & 24 \\
\hline 724945 & SAN JOSE INTL AP & $\mathrm{CA}$ & 37.367 & -121.933 & -8 & 16 & II & 12 \\
\hline 722897 & SAN LUIS CO RGNL & $\mathrm{CA}$ & 35.233 & -120.633 & -8 & 66 & II & 12 \\
\hline 723830 & SANDBERG & $\mathrm{CA}$ & 34.750 & -118.717 & -8 & 1377 & III & 10 \\
\hline 722977 & $\begin{array}{l}\text { SANTA ANA JOHN WAYNE } \\
\text { AP }\end{array}$ & CA & 33.683 & -117.867 & -8 & 16 & II & 12 \\
\hline 723925 & $\begin{array}{l}\text { SANTA BARBARA } \\
\text { MUNICIPAL AP }\end{array}$ & CA & 34.433 & -119.850 & -8 & 3 & I & 12 \\
\hline 723940 & SANTA MARIA PUBLIC ARPT & CA & 34.917 & -120.467 & -8 & 77 & $\mathrm{I}$ & 24 \\
\hline 722885 & SANTA MONICA MUNI & $\mathrm{CA}$ & 34.017 & -118.450 & -8 & 53 & II & 12 \\
\hline 724957 & SANTA ROSA (AWOS) & $\mathrm{CA}$ & 38.517 & -122.817 & -8 & 38 & II & 12 \\
\hline 725847 & SOUTH LAKE TAHOE & $\mathrm{CA}$ & 38.900 & -120.000 & -8 & 1909 & II & 12 \\
\hline 724920 & $\begin{array}{l}\text { STOCKTON METROPOLITAN } \\
\text { ARPT }\end{array}$ & $\mathrm{CA}$ & 37.900 & -121.233 & -8 & 7 & II & 12 \\
\hline 745160 & TRAVIS FIELD AFB & $\mathrm{CA}$ & 38.267 & -121.933 & -8 & 18 & II & 12 \\
\hline 725846 & TRUCKEE-TAHOE & $\mathrm{CA}$ & 39.317 & -120.133 & -8 & 1798 & II & 12 \\
\hline 690150 & TWENTYNINE PALMS & $\mathrm{CA}$ & 34.300 & -116.167 & -8 & 626 & II & 12 \\
\hline 725905 & UKIAH MUNICIPAL AP & $\mathrm{CA}$ & 39.133 & -123.200 & -8 & 189 & II & 12 \\
\hline 722886 & VAN NUYS AIRPORT & $\mathrm{CA}$ & 34.217 & -118.483 & -8 & 235 & II & 12 \\
\hline 723896 & VISALIA MUNI (AWOS) & $\mathrm{CA}$ & 36.317 & -119.400 & -8 & 89 & II & 12 \\
\hline 724838 & YUBA CO & $\mathrm{CA}$ & 39.100 & -121.567 & -8 & 19 & II & 12 \\
\hline 724698 & $\begin{array}{l}\text { AKRON WASHINGTON CO } \\
\text { AP }\end{array}$ & $\mathrm{CO}$ & 40.167 & -103.233 & -7 & 1421 & II & 12 \\
\hline 724620 & $\begin{array}{l}\text { ALAMOSA SAN LUIS VALLEY } \\
\text { RGNL }\end{array}$ & $\mathrm{CO}$ & 37.433 & -105.867 & -7 & 2296 & II & 24 \\
\hline 724676 & ASPEN PITKIN CO SAR & $\mathrm{CO}$ & 39.217 & -106.867 & -7 & 2444 & II & 12 \\
\hline 724695 & $\begin{array}{l}\text { AURORA BUCKLEY FIELD } \\
\text { ANGB }\end{array}$ & $\mathrm{CO}$ & 39.717 & -104.750 & -7 & 1726 & II & 12 \\
\hline 724699 & $\begin{array}{l}\text { BROOMFIELD/JEFFCO } \\
\text { [BOULDER - SURFRAD] }\end{array}$ & $\mathrm{CO}$ & 40.130 & -105.240 & -7 & 1689 & III & 12 \\
\hline 724660 & $\begin{array}{l}\text { COLORADO SPRINGS MUNI } \\
\text { AP }\end{array}$ & $\mathrm{CO}$ & 38.817 & -104.717 & -7 & 1872 & II & 24 \\
\hline 724767 & CORTEZ/MONTEZUMA CO & $\mathrm{CO}$ & 37.300 & -108.633 & -7 & 1803 & II & 12 \\
\hline 725700 & CRAIG-MOFFAT & $\mathrm{CO}$ & 40.500 & -107.533 & -7 & 1915 & II & 12 \\
\hline 725650 & DENVER INTL AP & $\mathrm{CO}$ & 39.833 & -104.650 & -7 & 1650 & $\mathrm{I}$ & 12 \\
\hline 724666 & $\begin{array}{l}\text { DENVER/CENTENNIAL } \\
\text { [GOLDEN - NREL] }\end{array}$ & $\mathrm{CO}$ & 39.742 & -105.179 & -7 & 1829 & II & 12 \\
\hline 724625 & DURANGO/LA PLATA CO & $\mathrm{CO}$ & 37.150 & -107.750 & -7 & 2038 & II & 12 \\
\hline 724675 & EAGLE COUNTY AP & $\mathrm{CO}$ & 39.650 & -106.917 & -7 & 1980 & II & 21 \\
\hline 724769 & FORT COLLINS (AWOS) & $\mathrm{CO}$ & 40.450 & -105.017 & -7 & 1529 & II & 12 \\
\hline 724760 & $\begin{array}{l}\text { GRAND JUNCTION WALKER } \\
\text { FIELD }\end{array}$ & $\mathrm{CO}$ & 39.133 & -108.533 & -7 & 1475 & I & 24 \\
\hline 724768 & GREELEY/WELD (AWOS) & $\mathrm{CO}$ & 40.433 & -104.633 & -7 & 1420 & II & 12 \\
\hline 724677 & GUNNISON CO. (AWOS) & $\mathrm{CO}$ & 38.533 & -106.933 & -7 & 2339 & II & 12 \\
\hline 725715 & HAYDEN/YAMPA (AWOS) & $\mathrm{CO}$ & 40.483 & -107.217 & -7 & 2012 & II & 12 \\
\hline 724635 & LA JUNTA MUNICIPAL AP & $\mathrm{CO}$ & 38.050 & -103.533 & -7 & 1281 & II & 12 \\
\hline
\end{tabular}




\begin{tabular}{|c|c|c|c|c|c|c|c|c|}
\hline USAF & Station Name & State & $\begin{array}{l}\text { Lati- } \\
\text { tude }\end{array}$ & $\begin{array}{l}\text { Longi- } \\
\text { tude }\end{array}$ & $\begin{array}{l}\text { Time } \\
\text { Zone }\end{array}$ & $\begin{array}{c}\text { Eleva- } \\
\text { tion }\end{array}$ & $\begin{array}{l}\text { NSRDB } \\
\text { Class }\end{array}$ & $\begin{array}{l}\text { Pool } \\
\text { Years }\end{array}$ \\
\hline 724636 & LAMAR MUNICIPAL & $\mathrm{CO}$ & 38.067 & -102.683 & -7 & 1129 & III & 10 \\
\hline 724673 & LEADVILLE/LAKE CO. & $\mathrm{CO}$ & 39.217 & -106.317 & -7 & 3026 & II & 12 \\
\hline 724665 & LIMON & $\mathrm{CO}$ & 39.183 & -103.717 & -7 & 1695 & I & 12 \\
\hline 724765 & MONTROSE CO. ARPT & $\mathrm{CO}$ & 38.500 & -107.900 & -7 & 1755 & II & 12 \\
\hline 724640 & PUEBLO MEMORIAL AP & $\mathrm{CO}$ & 38.283 & -104.500 & -7 & 1428 & II & 24 \\
\hline 725717 & RIFLE/GARFIELD RGNL & $\mathrm{CO}$ & 39.533 & -107.717 & -7 & 1691 & III & 12 \\
\hline 724645 & $\begin{array}{l}\text { TRINIDAD LAS ANIMAS } \\
\text { COUNTY AP }\end{array}$ & $\mathrm{CO}$ & 37.267 & -104.333 & -7 & 1751 & II & 12 \\
\hline 725040 & $\begin{array}{l}\text { BRIDGEPORT SIKORSKY } \\
\text { MEMORIAL }\end{array}$ & CT & 41.183 & -73.150 & -5 & 3 & 1 & 24 \\
\hline 725086 & DANBURY MUNICIPAL & CT & 41.367 & -73.483 & -5 & 139 & II & 12 \\
\hline 725046 & GROTON NEW LONDON AP & CT & 41.333 & -72.050 & -5 & 3 & II & 12 \\
\hline 725080 & $\begin{array}{l}\text { HARTFORD BRADLEY INTL } \\
\text { AP }\end{array}$ & CT & 41.933 & -72.683 & -5 & 49 & 1 & 24 \\
\hline 725087 & HARTFORD BRAINARD FD & $\mathrm{CT}$ & 41.733 & -72.650 & -5 & 6 & II & 12 \\
\hline 725045 & $\begin{array}{l}\text { NEW HAVEN TWEED } \\
\text { AIRPORT }\end{array}$ & CT & 41.267 & -72.883 & -5 & 2 & II & 12 \\
\hline 725029 & OXFORD (AWOS) & CT & 41.483 & -73.133 & -5 & 222 & III & 12 \\
\hline 724088 & DOVER AFB & $\mathrm{DE}$ & 39.133 & -75.467 & -5 & 7 & II & 12 \\
\hline 724089 & $\begin{array}{l}\text { WILMINGTON NEW CASTLE } \\
\text { CNTY AP }\end{array}$ & DE & 39.667 & -75.600 & -5 & 23 & 1 & 24 \\
\hline 722215 & CRESTVIEW BOB SIKES AP & $\mathrm{FL}$ & 30.783 & -86.517 & -6 & 58 & II & 12 \\
\hline 722056 & DAYTONA BEACH INTL AP & FL & 29.183 & -81.067 & -5 & 9 & I & 24 \\
\hline 722039 & FORT LAUDERDALE & $\mathrm{FL}$ & 26.200 & -80.167 & -5 & 4 & II & 12 \\
\hline 722025 & $\begin{array}{l}\text { FORT LAUDERDALE } \\
\text { HOLLYWOOD INT }\end{array}$ & $\mathrm{FL}$ & 26.067 & -80.150 & -5 & 3 & II & 12 \\
\hline 722106 & FORT MYERS PAGE FIELD & $\mathrm{FL}$ & 26.583 & -81.867 & -5 & 5 & 1 & 12 \\
\hline 722146 & GAINESVILLE REGIONAL AP & FL & 29.700 & -82.283 & -5 & 41 & I & 12 \\
\hline 722026 & HOMESTEAD AFB & FL & 25.483 & -80.383 & -5 & 5 & II & 12 \\
\hline 722060 & JACKSONVILLE INTL ARPT & $\mathrm{FL}$ & 30.500 & -81.700 & -5 & 8 & $\mathrm{I}$ & 24 \\
\hline 722065 & JACKSONVILLE NAS & FL & 30.233 & -81.667 & -5 & 9 & II & 12 \\
\hline 722068 & JACKSONVILLE/CRAIG & FL & 30.333 & -81.517 & -5 & 12 & II & 12 \\
\hline 722010 & KEY WEST INTL ARPT & $\mathrm{FL}$ & 24.550 & -81.750 & -5 & 1 & $\mathrm{I}$ & 24 \\
\hline 722015 & KEY WEST NAS & FL & 24.583 & -81.683 & -5 & 7 & II & 12 \\
\hline 722119 & LAKELAND LINDER RGN & $\mathrm{FL}$ & 27.983 & -82.017 & -5 & 43 & II & 12 \\
\hline 747880 & MACDILL AFB & $\mathrm{FL}$ & 27.850 & -82.517 & -5 & 8 & II & 12 \\
\hline 722016 & MARATHON AIRPORT & FL & 24.733 & -81.050 & -5 & 2 & II & 12 \\
\hline 722066 & MAYPORT NS & $\mathrm{FL}$ & 30.400 & -81.417 & -5 & 5 & II & 12 \\
\hline 722040 & MELBOURNE REGIONAL AP & $\mathrm{FL}$ & 28.117 & -80.650 & -5 & 11 & II & 12 \\
\hline 722020 & MIAMI INTL AP & FL & 25.817 & -80.300 & -5 & 11 & 1 & 24 \\
\hline 722029 & MIAMI/KENDALL-TAMIA & FL & 25.650 & -80.433 & -5 & 3 & II & 12 \\
\hline 722024 & MIAMI/OPA LOCKA & FL & 25.900 & -80.283 & -5 & 3 & II & 12 \\
\hline 722038 & NAPLES MUNICIPAL & FL & 26.150 & -81.767 & -5 & 3 & III & 10 \\
\hline 747946 & NASA SHUTTLE FCLTY & $\mathrm{FL}$ & 28.617 & -80.717 & -5 & 3 & III & 12 \\
\hline 722055 & OCALA MUNI (AWOS) & $\mathrm{FL}$ & 29.167 & -82.217 & -5 & 27 & II & 12 \\
\hline 722053 & ORLANDO EXECUTIVE AP & $\mathrm{FL}$ & 28.550 & -81.333 & -5 & 33 & II & 12 \\
\hline 722050 & ORLANDO INTL ARPT & FL & 28.433 & -81.333 & -5 & 29 & I & 12 \\
\hline
\end{tabular}




\begin{tabular}{|c|c|c|c|c|c|c|c|c|}
\hline USAF & Station Name & State & $\begin{array}{l}\text { Lati- } \\
\text { tude }\end{array}$ & $\begin{array}{l}\text { Longi- } \\
\text { tude }\end{array}$ & $\begin{array}{l}\text { Time } \\
\text { Zone }\end{array}$ & $\begin{array}{c}\text { Eleva- } \\
\text { tion }\end{array}$ & $\begin{array}{l}\text { NSRDB } \\
\text { Class }\end{array}$ & $\begin{array}{l}\text { Pool } \\
\text { Years }\end{array}$ \\
\hline 722057 & $\begin{array}{l}\text { ORLANDO SANFORD } \\
\text { AIRPORT }\end{array}$ & $\mathrm{FL}$ & 28.783 & -81.250 & -5 & 17 & II & 12 \\
\hline 722245 & PANAMA CITY BAY CO & FL & 30.200 & -85.683 & -6 & 6 & II & 12 \\
\hline 722225 & $\begin{array}{l}\text { PENSACOLA FOREST } \\
\text { SHERMAN NAS }\end{array}$ & $\mathrm{FL}$ & 30.350 & -87.317 & -6 & 10 & II & 12 \\
\hline 722223 & PENSACOLA REGIONAL AP & FL & 30.483 & -87.183 & -6 & 34 & $\mathrm{I}$ & 12 \\
\hline 722115 & SARASOTA BRADENTON & $\mathrm{FL}$ & 27.383 & -82.550 & -5 & 10 & II & 12 \\
\hline 722108 & SOUTHWEST FLORIDA I & FL & 26.533 & -81.750 & -5 & 9 & II & 12 \\
\hline 722103 & ST LUCIE CO INTL & $\mathrm{FL}$ & 27.483 & -80.367 & -5 & 7 & II & 12 \\
\hline 722104 & $\begin{array}{l}\text { ST PETERSBURG ALBERT } \\
\text { WHITTED }\end{array}$ & $\mathrm{FL}$ & 27.767 & -82.633 & -5 & 2 & II & 12 \\
\hline 722116 & ST PETERSBURG CLEAR & $\mathrm{FL}$ & 27.900 & -82.683 & -5 & 3 & II & 12 \\
\hline 722140 & $\begin{array}{l}\text { TALLAHASSEE REGIONAL } \\
\text { AP [ISIS] }\end{array}$ & FL & 30.380 & -84.370 & -5 & 21 & I & 24 \\
\hline 722110 & TAMPA INTERNATIONAL AP & FL & 27.967 & -82.533 & -5 & 6 & I & 24 \\
\hline 747750 & TYNDALL AFB & $\mathrm{FL}$ & 30.067 & -85.583 & -6 & 7 & II & 12 \\
\hline 722210 & VALPARAISO ELGIN AFB & $\mathrm{FL}$ & 30.483 & -86.517 & -6 & 20 & II & 12 \\
\hline 747770 & VALPARAISO HURLBURT & $\mathrm{FL}$ & 30.417 & -86.683 & -6 & 12 & II & 12 \\
\hline 722045 & $\begin{array}{l}\text { VERO BEACH MUNICIPAL } \\
\text { ARPT }\end{array}$ & FL & 27.650 & -80.417 & -5 & 7 & 1 & 12 \\
\hline 722030 & $\begin{array}{l}\text { WEST PALM BEACH INTL } \\
\text { ARPT }\end{array}$ & $\mathrm{FL}$ & 26.683 & -80.100 & -5 & 6 & II & 24 \\
\hline 722226 & WHITING FIELD NAAS & $\mathrm{FL}$ & 30.717 & -87.017 & -6 & 54 & II & 12 \\
\hline 722160 & $\begin{array}{l}\text { ALBANY DOUGHERTY } \\
\text { COUNTY AP }\end{array}$ & GA & 31.533 & -84.183 & -5 & 58 & II & 12 \\
\hline 722135 & ALMA BACON COUNTY AP & GA & 31.533 & -82.500 & -5 & 63 & II & 12 \\
\hline 723110 & ATHENS BEN EPPS AP & GA & 33.950 & -83.333 & -5 & 244 & $\mathrm{I}$ & 24 \\
\hline 722190 & $\begin{array}{l}\text { ATLANTA HARTSFIELD INTL } \\
\text { AP }\end{array}$ & GA & 33.633 & -84.433 & -5 & 308 & 1 & 24 \\
\hline 722180 & AUGUSTA BUSH FIELD & GA & 33.367 & -81.967 & -5 & 40 & I & 24 \\
\hline 722136 & BRUNSWICK GOLDEN IS & GA & 31.250 & -81.467 & -5 & 8 & II & 12 \\
\hline 722137 & $\begin{array}{l}\text { BRUNSWICK MALCOLM } \\
\text { MCKINNON AP }\end{array}$ & GA & 31.150 & -81.383 & -5 & 4 & II & 12 \\
\hline 722255 & $\begin{array}{l}\text { COLUMBUS } \\
\text { METROPOLITAN ARPT }\end{array}$ & GA & 32.517 & -84.950 & -6 & 120 & 1 & 24 \\
\hline 722196 & DEKALB PEACHTREE & GA & 33.867 & -84.300 & -5 & 313 & II & 12 \\
\hline 722250 & FORT BENNING LAWSON & GA & 32.350 & -85.000 & -6 & 88 & II & 12 \\
\hline 722195 & FULTON CO ARPT BROW & GA & 33.767 & -84.517 & -5 & 263 & II & 12 \\
\hline 747804 & HUNTER AAF & GA & 32.000 & -81.150 & -5 & 13 & II & 12 \\
\hline 722170 & $\begin{array}{l}\text { MACON MIDDLE GA } \\
\text { REGIONAL AP }\end{array}$ & GA & 32.683 & -83.650 & -5 & 108 & I & 24 \\
\hline 722270 & MARIETTA DOBBINS AFB & GA & 33.917 & -84.517 & -5 & 330 & II & 12 \\
\hline 747810 & MOODY AFB/VALDOSTA & GA & 30.967 & -83.200 & -5 & 71 & II & 12 \\
\hline 723200 & ROME R B RUSSELL AP & GA & 34.350 & -85.167 & -5 & 195 & III & 12 \\
\hline 722070 & SAVANNAH INTL AP & GA & 32.117 & -81.200 & -5 & 14 & 1 & 24 \\
\hline 722166 & VALDOSTA WB AIRPORT & GA & 30.783 & -83.283 & -5 & 61 & II & 12 \\
\hline 722175 & WARNER ROBINS AFB & GA & 32.633 & -83.600 & -5 & 92 & II & 12 \\
\hline 912180 & ANDERSEN AFB & GU & 13.567 & 144.917 & 10 & 162 & II & 12 \\
\hline 912120 & GUAM WFO & GU & 13.483 & 144.800 & 10 & 77 & II & 24 \\
\hline
\end{tabular}




\begin{tabular}{|c|c|c|c|c|c|c|c|c|}
\hline USAF & Station Name & State & $\begin{array}{l}\text { Lati- } \\
\text { tude }\end{array}$ & $\begin{array}{l}\text { Longi- } \\
\text { tude }\end{array}$ & $\begin{array}{l}\text { Time } \\
\text { Zone }\end{array}$ & $\begin{array}{c}\text { Eleva- } \\
\text { tion }\end{array}$ & $\begin{array}{l}\text { NSRDB } \\
\text { Class }\end{array}$ & $\begin{array}{l}\text { Pool } \\
\text { Years }\end{array}$ \\
\hline 911780 & BARBERS POINT NAS & $\mathrm{HI}$ & 21.317 & -158.067 & -10 & 15 & II & 12 \\
\hline 912850 & HILO INTERNATIONAL AP & $\mathrm{HI}$ & 19.717 & -155.050 & -10 & 9 & 1 & 24 \\
\hline 911820 & HONOLULU INTL ARPT & $\mathrm{HI}$ & 21.317 & -157.933 & -10 & 2 & I & 24 \\
\hline 911900 & KAHULUI AIRPORT & $\mathrm{HI}$ & 20.900 & -156.433 & -10 & 16 & 1 & 24 \\
\hline 911760 & KANEOHE BAY MCAS & $\mathrm{HI}$ & 21.450 & -157.783 & -10 & 3 & II & 12 \\
\hline 911904 & KAPALUA & $\mathrm{HI}$ & 20.950 & -156.633 & -10 & 80 & II & 12 \\
\hline 911975 & KONA INTL AT KEAHOL & $\mathrm{HI}$ & 19.733 & -156.050 & -10 & 15 & III & 10 \\
\hline 911905 & LANAI & $\mathrm{HI}$ & 20.783 & -156.950 & -10 & 409 & II & 12 \\
\hline 911650 & LIHUE AIRPORT & $\mathrm{HI}$ & 21.983 & -159.333 & -10 & 31 & 1 & 24 \\
\hline 911860 & MOLOKAI (AMOS) & $\mathrm{HI}$ & 21.150 & -157.100 & -10 & 137 & II & 12 \\
\hline 725457 & ALGONA & $\mathrm{IA}$ & 43.083 & -94.267 & -6 & 372 & III & 10 \\
\hline 725453 & ATLANTIC & IA & 41.400 & -95.050 & -6 & 360 & III & 10 \\
\hline 725486 & BOONE MUNI & IA & 42.050 & -93.850 & -6 & 354 & III & 10 \\
\hline 725455 & $\begin{array}{l}\text { BURLINGTON MUNICIPAL } \\
\text { AP }\end{array}$ & IA & 40.783 & -91.117 & -6 & 211 & II & 12 \\
\hline 725468 & CARROLL & $\mathrm{IA}$ & 42.050 & -94.783 & -6 & 375 & III & 10 \\
\hline 725450 & $\begin{array}{l}\text { CEDAR RAPIDS MUNICIPAL } \\
\text { AP }\end{array}$ & IA & 41.883 & -91.717 & -6 & 256 & II & 12 \\
\hline 725469 & CHARITON & IA & 41.033 & -93.367 & -6 & 320 & III & 10 \\
\hline 725463 & CHARLES CITY & IA & 43.067 & -92.617 & -6 & 343 & III & 10 \\
\hline 725479 & CLARINDA & $\mathrm{IA}$ & 40.717 & -95.033 & -6 & 303 & III & 10 \\
\hline 725473 & CLINTON MUNI (AWOS) & $\mathrm{IA}$ & 41.833 & -90.333 & -6 & 216 & II & 12 \\
\hline 725497 & COUNCIL BLUFFS & $\mathrm{IA}$ & 41.267 & -95.767 & -6 & 382 & III & 10 \\
\hline 725474 & CRESTON & $\mathrm{IA}$ & 41.017 & -94.367 & -6 & 394 & III & 10 \\
\hline 725476 & DECORAH & $\mathrm{IA}$ & 43.283 & -91.733 & -6 & 353 & III & 10 \\
\hline 725477 & DENISON & $\mathrm{IA}$ & 41.983 & -95.383 & -6 & 388 & III & 10 \\
\hline 725460 & DES MOINES INTL AP & IA & 41.533 & -93.667 & -6 & 292 & $\mathrm{I}$ & 24 \\
\hline 725470 & DUBUQUE REGIONAL AP & $\mathrm{IA}$ & 42.400 & -90.700 & -6 & 322 & 1 & 12 \\
\hline 726499 & ESTHERVILLE MUNI & IA & 43.400 & -94.750 & -6 & 401 & II & 12 \\
\hline 726498 & FAIR FIELD & $\mathrm{IA}$ & 41.050 & -91.983 & -6 & 244 & III & 10 \\
\hline 725490 & FORT DODGE (AWOS) & $\mathrm{IA}$ & 42.550 & -94.183 & -6 & 355 & II & 12 \\
\hline 725483 & FORT MADISON & $\mathrm{IA}$ & 40.667 & -91.333 & -6 & 221 & III & 10 \\
\hline 725456 & KEOKUK MUNI & IA & 40.467 & -91.433 & -6 & 205 & III & 10 \\
\hline 725493 & KNOXVILLE & $\mathrm{IA}$ & 41.300 & -93.117 & -6 & 283 & III & 10 \\
\hline 725484 & LE MARS & IA & 42.783 & -96.200 & -6 & 365 & III & 10 \\
\hline 725485 & $\begin{array}{l}\text { MASON CITY MUNICIPAL } \\
\text { ARPT }\end{array}$ & IA & 43.150 & -93.333 & -6 & 364 & I & 24 \\
\hline 725475 & MONTICELLO MUNI & IA & 42.233 & -91.167 & -6 & 259 & III & 10 \\
\hline 725487 & MUSCATINE & IA & 41.367 & -91.150 & -6 & 167 & III & 10 \\
\hline 725464 & NEWTON MUNI & IA & 41.683 & -93.017 & -6 & 290 & III & 10 \\
\hline 725488 & OELWEN & $\mathrm{IA}$ & 42.683 & -91.967 & -6 & 328 & III & 10 \\
\hline 725489 & ORANGE CITY & IA & 42.983 & -96.067 & -6 & 431 & III & 10 \\
\hline 725465 & OTTUMWA INDUSTRIAL AP & $\mathrm{IA}$ & 41.100 & -92.450 & -6 & 257 & II & 12 \\
\hline 725494 & RED OAK & $\mathrm{IA}$ & 41.017 & -95.267 & -6 & 318 & III & 10 \\
\hline 725495 & SHELDON & $\mathrm{IA}$ & 43.217 & -95.833 & -6 & 432 & III & 10 \\
\hline 725467 & SHENANDOAH MUNI & IA & 40.750 & -95.417 & -6 & 296 & III & 10 \\
\hline 725570 & $\begin{array}{l}\text { SIOUX CITY SIOUX } \\
\text { GATEWAY AP }\end{array}$ & IA & 42.383 & -96.383 & -6 & 333 & I & 24 \\
\hline
\end{tabular}




\begin{tabular}{|c|c|c|c|c|c|c|c|c|}
\hline USAF & Station Name & State & $\begin{array}{l}\text { Lati- } \\
\text { tude }\end{array}$ & $\begin{array}{l}\text { Longi- } \\
\text { tude }\end{array}$ & $\begin{array}{l}\text { Time } \\
\text { Zone }\end{array}$ & $\begin{array}{c}\text { Eleva- } \\
\text { tion }\end{array}$ & $\begin{array}{l}\text { NSRDB } \\
\text { Class }\end{array}$ & $\begin{array}{l}\text { Pool } \\
\text { Years }\end{array}$ \\
\hline 726500 & SPENCER & IA & 43.167 & -95.150 & -6 & 408 & II & 12 \\
\hline 725496 & STORM LAKE & $\mathrm{IA}$ & 42.600 & -95.233 & -6 & 454 & III & 10 \\
\hline 725454 & WASHINGTON & $\mathrm{IA}$ & 41.283 & -91.667 & -6 & 230 & III & 10 \\
\hline 725480 & WATERLOO MUNICIPAL AP & IA & 42.550 & -92.400 & -6 & 264 & 1 & 24 \\
\hline 725478 & WEBSTER CITY & $\mathrm{IA}$ & 42.433 & -93.867 & -6 & 342 & III & 10 \\
\hline 726810 & BOISE AIR TERMINAL [UO] & ID & 43.620 & -116.210 & -7 & 701 & 1 & 24 \\
\hline 725867 & BURLEY MUNICIPAL ARPT & ID & 42.533 & -113.767 & -7 & 1267 & II & 12 \\
\hline 726813 & CALDWELL (AWOS) & ID & 43.633 & -116.633 & -7 & 740 & III & 12 \\
\hline 727834 & COEUR D`ALENE(AWOS) & ID & 47.767 & -116.817 & -8 & 707 & II & 12 \\
\hline 725865 & HAILEY/FRIEDMAN MEM & ID & 43.500 & -114.300 & -7 & 1620 & II & 12 \\
\hline 725785 & $\begin{array}{l}\text { IDAHO FALLS FANNING } \\
\text { FIELD }\end{array}$ & ID & 43.517 & -112.067 & -7 & 1441 & II & 12 \\
\hline 725866 & $\begin{array}{l}\text { JOSLIN FLD MAGIC VA } \\
\text { [TWIN FALLS - UO] }\end{array}$ & ID & 42.550 & -114.350 & -7 & 1200 & II & 12 \\
\hline 727830 & $\begin{array}{l}\text { LEWISTON NEZ PERCE } \\
\text { CNTY AP }\end{array}$ & ID & 46.367 & -117.017 & -8 & 438 & I & 12 \\
\hline 725786 & MALAD CITY & ID & 42.150 & -112.283 & -7 & 1362 & II & 12 \\
\hline 726815 & MOUNTAIN HOME AFB & ID & 43.050 & -115.867 & -7 & 912 & II & 12 \\
\hline 725780 & POCATELLO REGIONAL AP & ID & 42.917 & -112.567 & -7 & 1353 & I & 24 \\
\hline 726865 & SALMON/LEMHI (AWOS) & ID & 45.117 & -113.883 & -7 & 1233 & III & 12 \\
\hline 725868 & SODA SPRINGS/TIGERT & ID & 42.650 & -111.583 & -7 & 1780 & II & 12 \\
\hline 744655 & AURORA MUNICIPAL & IL & 41.767 & -88.467 & -6 & 215 & II & 12 \\
\hline 724338 & BELLEVILLE SCOTT AFB & IL & 38.550 & -89.850 & -6 & 135 & II & 12 \\
\hline 725314 & CAHOKIA/ST. LOUIS & IL & 38.567 & -90.150 & -6 & 126 & II & 12 \\
\hline 724397 & CENTRAL ILLINOIS RG & $\mathrm{IL}$ & 40.467 & -88.917 & -6 & 272 & II & 12 \\
\hline 725340 & CHICAGO MIDWAY AP & $\mathrm{IL}$ & 41.783 & -87.750 & -6 & 186 & II & 12 \\
\hline 725300 & CHICAGO OHARE INTL AP & IL & 41.983 & -87.917 & -6 & 201 & I & 24 \\
\hline 725347 & CHICAGO/WAUKEGAN & IL & 42.417 & -87.867 & -6 & 222 & II & 12 \\
\hline 725316 & DECATUR & $\mathrm{IL}$ & 39.833 & -88.867 & -6 & 213 & II & 12 \\
\hline 724339 & MARION REGIONAL & IL & 37.750 & -89.017 & -6 & 144 & II & 12 \\
\hline 725440 & MOLINE QUAD CITY INTL AP & IL & 41.467 & -90.517 & -6 & 180 & $\mathrm{I}$ & 24 \\
\hline 724335 & MOUNT VERNON (AWOS) & IL & 38.317 & -88.867 & -6 & 146 & II & 12 \\
\hline 725320 & $\begin{array}{l}\text { PEORIA GREATER PEORIA } \\
\text { AP }\end{array}$ & IL & 40.667 & -89.683 & -6 & 199 & I & 24 \\
\hline 724396 & QUINCY MUNI BALDWIN FLD & $\mathrm{IL}$ & 39.933 & -91.200 & -6 & 233 & II & 12 \\
\hline 725430 & $\begin{array}{l}\text { ROCKFORD GREATER } \\
\text { ROCKFORD AP }\end{array}$ & IL & 42.200 & -89.100 & -6 & 223 & I & 24 \\
\hline 724336 & SOUTHERN ILLINOIS & IL & 37.767 & -89.250 & -6 & 128 & II & 12 \\
\hline 724390 & SPRINGFIELD CAPITAL AP & IL & 39.850 & -89.683 & -6 & 179 & I & 24 \\
\hline 725326 & STERLING ROCKFALLS & $\mathrm{IL}$ & 41.750 & -89.667 & -6 & 197 & II & 12 \\
\hline 725315 & $\begin{array}{l}\text { UNIV OF ILLINOIS WI } \\
\text { [BONDVILLE - SURFRAD] }\end{array}$ & IL & 40.060 & -88.370 & -6 & 213 & II & 12 \\
\hline 725305 & W. CHICAGO/DU PAGE & $\mathrm{IL}$ & 41.917 & -88.250 & -6 & 231 & II & 12 \\
\hline 725336 & DELAWARE CO JOHNSON & IN & 40.233 & -85.400 & -5 & 293 & II & 12 \\
\hline 724320 & EVANSVILLE REGIONAL AP & IN & 38.050 & -87.533 & -6 & 116 & I & 24 \\
\hline 725330 & FORT WAYNE INTL AP & IN & 41.000 & -85.200 & -5 & 241 & $\mathrm{I}$ & 24 \\
\hline 725335 & GRISSOM ARB & IN & 40.650 & -86.150 & -5 & 253 & II & 12 \\
\hline 724365 & HUNTINGBURG & IN & 38.250 & -86.950 & -5 & 161 & III & 11 \\
\hline
\end{tabular}




\begin{tabular}{|c|c|c|c|c|c|c|c|c|}
\hline USAF & Station Name & State & $\begin{array}{l}\text { Lati- } \\
\text { tude }\end{array}$ & $\begin{array}{l}\text { Longi- } \\
\text { tude }\end{array}$ & $\begin{array}{l}\text { Time } \\
\text { Zone }\end{array}$ & $\begin{array}{c}\text { Eleva- } \\
\text { tion }\end{array}$ & $\begin{array}{c}\text { NSRDB } \\
\text { Class }\end{array}$ & $\begin{array}{l}\text { Pool } \\
\text { Years }\end{array}$ \\
\hline 724380 & INDIANAPOLIS INTL AP & IN & 39.717 & -86.267 & -5 & 241 & I & 24 \\
\hline 724386 & $\begin{array}{l}\text { LAFAYETTE PURDUE UNIV } \\
\text { AP }\end{array}$ & IN & 40.417 & -86.933 & -5 & 183 & II & 12 \\
\hline 724375 & MONROE CO & IN & 39.133 & -86.617 & -5 & 264 & II & 12 \\
\hline 725350 & $\begin{array}{l}\text { SOUTH BEND MICHIANA } \\
\text { RGNL AP }\end{array}$ & IN & 41.700 & -86.333 & -5 & 236 & I & 24 \\
\hline 724373 & $\begin{array}{l}\text { TERRE HAUTE HULMAN } \\
\text { REGIONAL A }\end{array}$ & IN & 39.450 & -87.300 & -5 & 175 & II & 12 \\
\hline 724507 & $\begin{array}{l}\text { CHANUTE MARTIN } \\
\text { JOHNSON AP }\end{array}$ & KS & 37.667 & -95.483 & -6 & 298 & II & 12 \\
\hline 724580 & $\begin{array}{l}\text { CONCORDIA BLOSSER } \\
\text { MUNI AP }\end{array}$ & $\mathrm{KS}$ & 39.550 & -97.650 & -6 & 448 & II & 12 \\
\hline 724510 & DODGE CITY REGIONAL AP & KS & 37.767 & -99.967 & -6 & 785 & II & 24 \\
\hline 724556 & EMPORIA MUNICIPAL AP & KS & 38.333 & -96.183 & -6 & 368 & II & 12 \\
\hline 724550 & $\begin{array}{l}\text { FORT RILEY MARSHALL } \\
\text { AAF }\end{array}$ & KS & 39.050 & -96.767 & -6 & 324 & III & 10 \\
\hline 724515 & $\begin{array}{l}\text { GARDEN CITY MUNICIPAL } \\
\text { AP }\end{array}$ & KS & 37.933 & -100.717 & -6 & 878 & II & 12 \\
\hline 724650 & GOODLAND RENNER FIELD & KS & 39.367 & -101.700 & -7 & 1111 & II & 24 \\
\hline 724517 & GREAT BEND (AWOS) & KS & 38.350 & -98.867 & -6 & 575 & II & 12 \\
\hline 724518 & HAYS MUNI (AWOS) & KS & 38.850 & -99.267 & -6 & 609 & II & 12 \\
\hline 724655 & HILL CITY MUNICIPAL AP & KS & 39.383 & -99.833 & -6 & 667 & II & 12 \\
\hline 724506 & $\begin{array}{l}\text { HUTCHINSON MUNICIPAL } \\
\text { AP }\end{array}$ & KS & 38.067 & -97.867 & -6 & 463 & II & 12 \\
\hline 724516 & LIBERAL MUNI & KS & 37.033 & -100.967 & -6 & 901 & II & 12 \\
\hline 724555 & MANHATTAN RGNL & KS & 39.133 & -96.667 & -6 & 330 & II & 12 \\
\hline 724505 & MCCONNELL AFB & KS & 37.617 & -97.267 & -6 & 414 & II & 12 \\
\hline 724509 & NEWTON (AWOS) & KS & 38.050 & -97.283 & -6 & 467 & III & 12 \\
\hline 724475 & $\begin{array}{l}\text { OLATHE JOHNSON CO } \\
\text { INDUSTRIAL }\end{array}$ & KS & 38.833 & -94.883 & -6 & 331 & II & 12 \\
\hline 724468 & OLATHE/JOHNSON CO. & KS & 38.850 & -94.733 & -6 & 334 & II & 12 \\
\hline 724585 & RUSSELL MUNICIPAL AP & KS & 38.883 & -98.817 & -6 & 566 & $\mathrm{I}$ & 12 \\
\hline 724586 & SALINA MUNICIPAL AP & KS & 38.817 & -97.667 & -6 & 385 & II & 12 \\
\hline 724565 & TOPEKA FORBES FIELD & KS & 38.950 & -95.667 & -6 & 325 & II & 12 \\
\hline 724560 & TOPEKA MUNICIPAL AP & KS & 39.067 & -95.633 & -6 & 269 & II & 24 \\
\hline 724500 & $\begin{array}{l}\text { WICHITA MID-CONTINENT } \\
\text { AP }\end{array}$ & KS & 37.650 & -97.433 & -6 & 402 & II & 24 \\
\hline 724504 & WICHITA/COL. JABARA & KS & 37.750 & -97.217 & -6 & 433 & III & 10 \\
\hline 746716 & $\begin{array}{l}\text { BOWLING GREEN WARREN } \\
\text { CO AP }\end{array}$ & KY & 36.983 & -86.433 & -6 & 161 & II & 12 \\
\hline 724210 & $\begin{array}{l}\text { CINCINNATI NORTHERN KY } \\
\text { AP }\end{array}$ & KY & 39.050 & -84.667 & -5 & 265 & 1 & 24 \\
\hline 746710 & FORT CAMPBELL AAF & KY & 36.667 & -87.483 & -6 & 173 & II & 12 \\
\hline 724240 & FORT KNOX GODMAN AAF & $\mathrm{KY}$ & 37.900 & -85.967 & -5 & 239 & II & 12 \\
\hline 724238 & HENDERSON CITY & $\mathrm{KY}$ & 37.817 & -87.683 & -6 & 117 & III & 12 \\
\hline 724236 & $\begin{array}{l}\text { JACKSON JULIAN CARROLL } \\
\text { AP }\end{array}$ & KY & 37.583 & -83.317 & -5 & 416 & I & 12 \\
\hline 724220 & $\begin{array}{l}\text { LEXINGTON BLUEGRASS } \\
\text { AP }\end{array}$ & KY & 38.033 & -84.600 & -5 & 294 & I & 24 \\
\hline 724243 & LONDON-CORBIN AP & $\mathrm{KY}$ & 37.083 & -84.083 & -5 & 362 & II & 12 \\
\hline
\end{tabular}




\begin{tabular}{|c|c|c|c|c|c|c|c|c|}
\hline USAF & Station Name & State & $\begin{array}{l}\text { Lati- } \\
\text { tude }\end{array}$ & $\begin{array}{l}\text { Longi- } \\
\text { tude }\end{array}$ & $\begin{array}{l}\text { Time } \\
\text { Zone }\end{array}$ & $\begin{array}{c}\text { Eleva- } \\
\text { tion }\end{array}$ & $\begin{array}{l}\text { NSRDB } \\
\text { Class }\end{array}$ & $\begin{array}{l}\text { Pool } \\
\text { Years }\end{array}$ \\
\hline 724235 & LOUISVILLE BOWMAN FIELD & KY & 38.233 & -85.667 & -5 & 165 & II & 12 \\
\hline 724230 & $\begin{array}{l}\text { LOUISVILLE STANDIFORD } \\
\text { FIELD }\end{array}$ & KY & 38.183 & -85.733 & -5 & 147 & 1 & 24 \\
\hline 724350 & $\begin{array}{l}\text { PADUCAH BARKLEY } \\
\text { REGIONAL AP }\end{array}$ & KY & 37.050 & -88.767 & -6 & 124 & 1 & 12 \\
\hline 724354 & SOMERSET(AWOS) & KY & 38.000 & -84.600 & -5 & 283 & III & 12 \\
\hline 722487 & $\begin{array}{l}\text { ALEXANDRIA ESLER } \\
\text { REGIONAL AP }\end{array}$ & LA & 31.400 & -92.300 & -6 & 34 & II & 12 \\
\hline 722485 & BARKSDALE AFB & LA & 32.500 & -93.667 & -6 & 54 & II & 12 \\
\hline 722317 & BATON ROUGE RYAN ARPT & LA & 30.533 & -91.150 & -6 & 20 & II & 24 \\
\hline 747540 & ENGLAND AFB & LA & 31.317 & -92.550 & -6 & 27 & III & 11 \\
\hline 722390 & FORT POLK AAF & LA & 31.050 & -93.183 & -6 & 102 & II & 12 \\
\hline 722406 & HOUMA-TERREBONNE & LA & 29.567 & -90.667 & -6 & 3 & II & 12 \\
\hline 722405 & LAFAYETTE REGIONAL AP & LA & 30.200 & -91.983 & -6 & 12 & II & 12 \\
\hline 722400 & $\begin{array}{l}\text { LAKE CHARLES REGIONAL } \\
\text { ARPT }\end{array}$ & LA & 30.117 & -93.233 & -6 & 5 & 1 & 24 \\
\hline 722404 & LAKE CHARLES WB AIRP & LA & 30.217 & -93.167 & -6 & 5 & III & 10 \\
\hline 722486 & MONROE REGIONAL AP & LA & 32.517 & -92.033 & -6 & 40 & II & 12 \\
\hline 722314 & NEW IBERIA NAAS & LA & 30.033 & -91.883 & -6 & 8 & II & 12 \\
\hline 722316 & $\begin{array}{l}\text { NEW ORLEANS ALVIN } \\
\text { CALLENDER F }\end{array}$ & LA & 29.817 & -90.017 & -6 & 2 & II & 12 \\
\hline 722310 & NEW ORLEANS INTL ARPT & LA & 30.000 & -90.250 & -6 & 1 & $\mathrm{I}$ & 24 \\
\hline 722315 & $\begin{array}{l}\text { NEW ORLEANS LAKEFRONT } \\
\text { AP }\end{array}$ & LA & 30.050 & -90.033 & -6 & 3 & II & 12 \\
\hline 722329 & PATTERSON MEMORIAL & LA & 29.717 & -91.333 & -6 & 3 & II & 12 \\
\hline 722484 & SHREVEPORT DOWNTOWN & LA & 32.533 & -93.750 & -6 & 55 & III & 10 \\
\hline 722480 & $\begin{array}{l}\text { SHREVEPORT REGIONAL } \\
\text { ARPT }\end{array}$ & LA & 32.450 & -93.817 & -6 & 77 & 1 & 24 \\
\hline 725067 & BARNSTABLE MUNI BOA & MA & 41.667 & -70.283 & -5 & 17 & II & 12 \\
\hline 725088 & BEVERLY MUNI & MA & 42.583 & -70.917 & -5 & 34 & II & 12 \\
\hline 725090 & BOSTON LOGAN INT'L ARPT & MA & 42.367 & -71.017 & -5 & 6 & I & 24 \\
\hline 744910 & CHICOPEE FALLS WESTO & MA & 42.200 & -72.533 & -5 & 75 & II & 12 \\
\hline 744904 & LAWRENCE MUNI & MA & 42.717 & -71.117 & -5 & 46 & II & 12 \\
\hline 725066 & MARTHAS VINEYARD & MA & 41.400 & -70.617 & -5 & 21 & II & 12 \\
\hline 725063 & NANTUCKET MEMORIAL AP & MA & 41.250 & -70.067 & -5 & 14 & II & 12 \\
\hline 725065 & NEW BEDFORD RGNL & MA & 41.667 & -70.950 & -5 & 25 & II & 12 \\
\hline 725075 & NORTH ADAMS & MA & 42.700 & -73.167 & -5 & 201 & III & 10 \\
\hline 725098 & NORWOOD MEMORIAL & MA & 42.183 & -71.183 & -5 & 15 & II & 12 \\
\hline 725060 & OTIS ANGB & MA & 41.650 & -70.517 & -5 & 40 & II & 12 \\
\hline 725064 & PLYMOUTH MUNICIPAL & MA & 41.917 & -70.733 & -5 & 45 & III & 11 \\
\hline 725073 & PROVINCETOWN (AWOS) & MA & 42.067 & -70.217 & -5 & 2 & II & 12 \\
\hline 744915 & $\begin{array}{l}\text { WESTFIELD BARNES MUNI } \\
\text { AP }\end{array}$ & MA & 42.150 & -72.717 & -5 & 83 & II & 12 \\
\hline 725095 & $\begin{array}{l}\text { WORCHESTER REGIONAL } \\
\text { ARPT }\end{array}$ & MA & 42.267 & -71.883 & -5 & 300 & I & 24 \\
\hline 745940 & ANDREWS AFB & $\mathrm{MD}$ & 38.817 & -76.867 & -5 & 86 & II & 12 \\
\hline 724060 & $\begin{array}{l}\text { BALTIMORE BLT- } \\
\text { WASHNGTN INT'L }\end{array}$ & MD & 39.167 & -76.683 & -5 & 45 & 1 & 24 \\
\hline 724066 & HAGERSTOWN RGNL RIC & MD & 39.700 & -77.733 & -5 & 220 & II & 12 \\
\hline
\end{tabular}




\begin{tabular}{|c|c|c|c|c|c|c|c|c|}
\hline USAF & Station Name & State & $\begin{array}{l}\text { Lati- } \\
\text { tude }\end{array}$ & $\begin{array}{l}\text { Longi- } \\
\text { tude }\end{array}$ & $\begin{array}{l}\text { Time } \\
\text { Zone }\end{array}$ & $\begin{array}{c}\text { Eleva- } \\
\text { tion }\end{array}$ & $\begin{array}{c}\text { NSRDB } \\
\text { Class }\end{array}$ & $\begin{array}{l}\text { Pool } \\
\text { Years }\end{array}$ \\
\hline 724040 & PATUXENT RIVER NAS & MD & 38.300 & -76.417 & -5 & 14 & II & 12 \\
\hline 724045 & $\begin{array}{l}\text { SALISBURY WICOMICO CO } \\
\text { AP }\end{array}$ & MD & 38.333 & -75.517 & -5 & 15 & II & 12 \\
\hline 726184 & AUBURN-LEWISTON & ME & 44.050 & -70.283 & -5 & 88 & II & 12 \\
\hline 726185 & AUGUSTA AIRPORT & $\mathrm{ME}$ & 44.317 & -69.800 & -5 & 107 & II & 12 \\
\hline 726088 & $\begin{array}{l}\text { BANGOR INTERNATIONAL } \\
\text { AP }\end{array}$ & ME & 44.800 & -68.817 & -5 & 56 & I & 12 \\
\hline 726077 & BAR HARBOR (AWOS) & $\mathrm{ME}$ & 44.450 & -68.367 & -5 & 26 & II & 12 \\
\hline 727120 & CARIBOU MUNICIPAL ARPT & ME & 46.867 & -68.033 & -5 & 190 & 1 & 24 \\
\hline 727033 & HOULTON INTL ARPT & $\mathrm{ME}$ & 46.117 & -67.800 & -5 & 150 & II & 12 \\
\hline 726196 & $\begin{array}{l}\text { MILLINOCKET MUNICIPAL } \\
\text { AP }\end{array}$ & ME & 45.650 & -68.683 & -5 & 124 & III & 12 \\
\hline 743920 & NAVAL AIR STATION & $\mathrm{ME}$ & 43.900 & -69.933 & -5 & 21 & II & 12 \\
\hline 726083 & NORTHERN AROOSTOOK & ME & 47.283 & -68.317 & -5 & 309 & III & 10 \\
\hline 726060 & PORTLAND INTL JETPORT & ME & 43.650 & -70.300 & -5 & 14 & 1 & 24 \\
\hline 727130 & PRESQUE ISLE MUNICIP & $\mathrm{ME}$ & 46.683 & -68.050 & -5 & 163 & II & 12 \\
\hline 726079 & ROCKLAND/KNOX(AWOS) & ME & 44.067 & -69.100 & -5 & 17 & II & 12 \\
\hline 726064 & SANFORD MUNI (AWOS) & $\mathrm{ME}$ & 43.400 & -70.717 & -5 & 74 & II & 12 \\
\hline 726073 & WATERVILLE (AWOS) & ME & 44.533 & -69.683 & -5 & 101 & II & 12 \\
\hline 727135 & WISCASSET & ME & 43.967 & -69.717 & -5 & 21 & III & 10 \\
\hline 726390 & $\begin{array}{l}\text { ALPENA COUNTY } \\
\text { REGIONAL AP }\end{array}$ & Ml & 45.067 & -83.583 & -5 & 210 & 1 & 24 \\
\hline 725374 & ANN ARBOR MUNICIPAL & $\mathrm{Ml}$ & 42.217 & -83.750 & -5 & 256 & II & 12 \\
\hline 725396 & $\begin{array}{l}\text { BATTLE CREEK KELLOGG } \\
\text { AP }\end{array}$ & MI & 42.300 & -85.250 & -5 & 283 & II & 12 \\
\hline 726355 & BENTON HARBOR/ROSS & $\mathrm{Ml}$ & 42.133 & -86.433 & -5 & 196 & II & 12 \\
\hline 726384 & CADILLAC WEXFORD CO AP & $\mathrm{Ml}$ & 44.283 & -85.417 & -5 & 396 & III & 12 \\
\hline 727344 & CHIPPEWA CO INTL & MI & 46.250 & -84.467 & -5 & 250 & II & 12 \\
\hline 725375 & DETROIT CITY AIRPORT & $\mathrm{Ml}$ & 42.400 & -83.000 & -5 & 190 & 1 & 12 \\
\hline 725370 & $\begin{array}{l}\text { DETROIT METROPOLITAN } \\
\text { ARPT }\end{array}$ & $\mathrm{Ml}$ & 42.217 & -83.350 & -5 & 194 & 1 & 24 \\
\hline 725376 & DETROIT WILLOW RUN AP & $\mathrm{Ml}$ & 42.233 & -83.533 & -5 & 218 & II & 12 \\
\hline 726480 & ESCANABA (AWOS) & $\mathrm{Ml}$ & 45.750 & -87.033 & -5 & 187 & II & 12 \\
\hline 726370 & FLINT BISHOP INTL ARPT & $\mathrm{MI}$ & 42.967 & -83.750 & -5 & 234 & $\mathrm{I}$ & 24 \\
\hline 726350 & $\begin{array}{l}\text { GRAND RAPIDS KENT } \\
\text { COUNTY INT' }\end{array}$ & MI & 42.883 & -85.517 & -5 & 242 & 1 & 24 \\
\hline 727440 & $\begin{array}{l}\text { HANCOCK HOUGHTON CO } \\
\text { AP }\end{array}$ & $\mathrm{Ml}$ & 47.167 & -88.500 & -5 & 327 & II & 12 \\
\hline 726380 & $\begin{array}{l}\text { HOUGHTON LAKE } \\
\text { ROSCOMMON CO AR }\end{array}$ & $\mathrm{Ml}$ & 44.367 & -84.683 & -5 & 351 & 1 & 24 \\
\hline 725378 & HOWELL & $\mathrm{Ml}$ & 42.633 & -83.983 & -5 & 293 & III & 11 \\
\hline 727437 & IRON MOUNTAIN/FORD & $\mathrm{MI}$ & 45.817 & -88.117 & -6 & 360 & II & 12 \\
\hline 727445 & IRONWOOD (AWOS) & $\mathrm{MI}$ & 46.533 & -90.133 & -6 & 375 & II & 12 \\
\hline 725395 & JACKSON REYNOLDS FIELD & $\mathrm{Ml}$ & 42.267 & -84.467 & -5 & 304 & II & 12 \\
\hline 726357 & KALAMAZOO BATTLE CR & $\mathrm{Ml}$ & 42.233 & -85.550 & -5 & 273 & II & 12 \\
\hline 725390 & $\begin{array}{l}\text { LANSING CAPITAL CITY } \\
\text { ARPT }\end{array}$ & MI & 42.783 & -84.583 & -5 & 256 & 1 & 24 \\
\hline 726385 & MANISTEE (AWOS) & $\mathrm{MI}$ & 44.267 & -86.250 & -5 & 189 & II & 12 \\
\hline 726487 & MENOMINEE (AWOS) & $\mathrm{Ml}$ & 45.133 & -87.633 & -6 & 191 & II & 12 \\
\hline
\end{tabular}




\begin{tabular}{|c|c|c|c|c|c|c|c|c|}
\hline USAF & Station Name & State & $\begin{array}{l}\text { Lati- } \\
\text { tude }\end{array}$ & $\begin{array}{l}\text { Longi- } \\
\text { tude }\end{array}$ & $\begin{array}{l}\text { Time } \\
\text { Zone }\end{array}$ & $\begin{array}{c}\text { Eleva- } \\
\text { tion }\end{array}$ & $\begin{array}{l}\text { NSRDB } \\
\text { Class }\end{array}$ & $\begin{array}{l}\text { Pool } \\
\text { Years }\end{array}$ \\
\hline 725377 & $\begin{array}{l}\text { MOUNT CLEMENS } \\
\text { SELFRIDGE FLD }\end{array}$ & Ml & 42.617 & -82.833 & -5 & 177 & II & 12 \\
\hline 726360 & MUSKEGON COUNTY ARPT & $\mathrm{Ml}$ & 43.167 & -86.233 & -5 & 190 & 1 & 24 \\
\hline 726375 & OAKLAND CO INTL & $\mathrm{Ml}$ & 42.667 & -83.417 & -5 & 306 & II & 12 \\
\hline 726395 & OSCODA WURTSMITH AFB & $\mathrm{MI}$ & 44.450 & -83.400 & -5 & 188 & III & 10 \\
\hline 727347 & $\begin{array}{l}\text { PELLSTON EMMET COUNTY } \\
\text { AP }\end{array}$ & MI & 45.567 & -84.783 & -5 & 218 & II & 12 \\
\hline 726379 & SAGINAW TRI CITY INTL AP & $\mathrm{Ml}$ & 43.533 & -84.083 & -5 & 201 & II & 12 \\
\hline 727340 & $\begin{array}{l}\text { SAULT STE MARIE } \\
\text { SANDERSON FIE }\end{array}$ & Ml & 46.467 & -84.350 & -5 & 219 & 1 & 24 \\
\hline 725384 & ST.CLAIR COUNTY INT & $\mathrm{Ml}$ & 42.917 & -82.533 & -5 & 198 & III & 11 \\
\hline 726387 & $\begin{array}{l}\text { TRAVERSE CITY CHERRY } \\
\text { CAPITAL }\end{array}$ & Ml & 44.733 & -85.583 & -5 & 188 & 1 & 24 \\
\hline 727504 & AITKIN NDB(AWOS) & $\mathrm{MN}$ & 46.550 & -93.683 & -6 & 367 & III & 12 \\
\hline 726589 & ALBERT LEA (AWOS) & $\mathrm{MN}$ & 43.683 & -93.367 & -6 & 383 & II & 12 \\
\hline 726557 & ALEXANDRIA MUNICIPAL AP & MN & 45.883 & -95.400 & -6 & 433 & II & 12 \\
\hline 727566 & AUSTIN MUNI & $\mathrm{MN}$ & 43.667 & -92.933 & -6 & 375 & III & 12 \\
\hline 727476 & $\begin{array}{l}\text { BAUDETTE INTERNATIONAL } \\
\text { AP }\end{array}$ & MN & 48.717 & -94.600 & -6 & 330 & III & 10 \\
\hline 727550 & BEMIDJI MUNICIPAL & MN & 47.500 & -94.933 & -6 & 420 & II & 12 \\
\hline 727507 & BENSON MUNI & MN & 45.317 & -95.650 & -6 & 317 & III & 11 \\
\hline 726555 & BRAINERD/WIELAND & MN & 46.400 & -94.133 & -6 & 374 & II & 12 \\
\hline 727503 & CAMBRIDGE MUNI & MN & 45.567 & -93.267 & -6 & 287 & III & 12 \\
\hline 726558 & CLOQUET (AWOS) & MN & 46.700 & -92.500 & -6 & 390 & III & 12 \\
\hline 727473 & CRANE LAKE (AWOS) & MN & 46.267 & -92.567 & -6 & 350 & II & 12 \\
\hline 727452 & CROOKSTON MUNI FLD & $\mathrm{MN}$ & 47.850 & -96.617 & -6 & 273 & III & 12 \\
\hline 727457 & DETROIT LAKES(AWOS) & $\mathrm{MN}$ & 46.833 & -95.883 & -6 & 426 & II & 12 \\
\hline 727450 & $\begin{array}{l}\text { DULUTH INTERNATIONAL } \\
\text { ARPT }\end{array}$ & MN & 46.833 & -92.217 & -6 & 433 & I & 24 \\
\hline 727459 & ELY MUNI & $\mathrm{MN}$ & 47.817 & -91.833 & -6 & 455 & II & 12 \\
\hline 727474 & EVELETH MUNI (AWOS) & $\mathrm{MN}$ & 47.400 & -92.500 & -6 & 421 & III & 12 \\
\hline 726586 & FAIRMONT MUNI(AWOS) & $\mathrm{MN}$ & 43.650 & -94.417 & -6 & 354 & II & 12 \\
\hline 726563 & FARIBAULT MUNI AWOS & $\mathrm{MN}$ & 44.333 & -93.317 & -6 & 322 & II & 12 \\
\hline 726560 & FERGUS FALLS(AWOS) & MN & 46.283 & -96.150 & -6 & 361 & II & 12 \\
\hline 726579 & FLYING CLOUD & $\mathrm{MN}$ & 44.817 & -93.450 & -6 & 283 & II & 12 \\
\hline 727505 & FOSSTON(AWOS) & $\mathrm{MN}$ & 47.583 & -95.767 & -6 & 388 & III & 12 \\
\hline 726547 & GLENWOOD (ASOS) & $\mathrm{MN}$ & 45.650 & -95.317 & -6 & 425 & III & 10 \\
\hline 727458 & GRAND RAPIDS(AWOS) & MN & 47.217 & -93.517 & -6 & 413 & II & 12 \\
\hline 727478 & HALLOCK & $\mathrm{MN}$ & 48.783 & -96.950 & -6 & 250 & III & 12 \\
\hline 727455 & $\begin{array}{l}\text { HIBBING CHISHOLM- } \\
\text { HIBBING AP }\end{array}$ & MN & 47.383 & -92.850 & -6 & 411 & II & 12 \\
\hline 726569 & HUTCHINSON (AWOS) & $\mathrm{MN}$ & 44.867 & -94.383 & -6 & 323 & III & 12 \\
\hline 727470 & $\begin{array}{l}\text { INTERNATIONAL FALLS } \\
\text { INTL AP }\end{array}$ & MN & 48.567 & -93.400 & -6 & 359 & 1 & 24 \\
\hline 726583 & LITCHFIELD MUNI & MN & 45.100 & -94.500 & -6 & 347 & II & 12 \\
\hline 726578 & LITTLE FALLS (AWOS) & MN & 45.950 & -94.350 & -6 & 342 & III & 12 \\
\hline 726585 & MANKATO(AWOS) & $\mathrm{MN}$ & 44.217 & -93.917 & -6 & 311 & II & 12 \\
\hline 726559 & MARSHALL/RYAN(AWOS) & MN & 44.450 & -95.817 & -6 & 359 & II & 12 \\
\hline
\end{tabular}




\begin{tabular}{|c|c|c|c|c|c|c|c|c|}
\hline USAF & Station Name & State & $\begin{array}{l}\text { Lati- } \\
\text { tude }\end{array}$ & $\begin{array}{l}\text { Longi- } \\
\text { tude }\end{array}$ & $\begin{array}{l}\text { Time } \\
\text { Zone }\end{array}$ & $\begin{array}{c}\text { Eleva- } \\
\text { tion }\end{array}$ & $\begin{array}{c}\text { NSRDB } \\
\text { Class }\end{array}$ & $\begin{array}{l}\text { Pool } \\
\text { Years }\end{array}$ \\
\hline 726575 & MINNEAPOLIS/CRYSTAL & MN & 45.067 & -93.350 & -6 & 265 & II & 12 \\
\hline 726580 & $\begin{array}{l}\text { MINNEAPOLIS-ST PAUL } \\
\text { INT'L ARP }\end{array}$ & MN & 44.883 & -93.233 & -6 & 254 & 1 & 24 \\
\hline 727475 & MORA MUNI (AWOS) & MN & 45.883 & -93.267 & -6 & 309 & II & 12 \\
\hline 726565 & MORRIS MUNI (AWOS) & MN & 45.567 & -95.967 & -6 & 344 & II & 12 \\
\hline 726567 & NEW ULM MUNI (AWOS) & MN & 44.317 & -94.500 & -6 & 308 & II & 12 \\
\hline 726544 & ORR & $\mathrm{MN}$ & 48.017 & -92.867 & -6 & 397 & III & 12 \\
\hline 726568 & OWATONNA (AWOS) & $\mathrm{MN}$ & 44.117 & -93.250 & -6 & 350 & III & 12 \\
\hline 727453 & $\begin{array}{l}\text { PARK RAPIDS MUNICIPAL } \\
\text { AP }\end{array}$ & MN & 46.900 & -95.067 & -6 & 437 & II & 12 \\
\hline 726566 & PIPESTONE (AWOS) & MN & 43.983 & -96.317 & -6 & 529 & II & 12 \\
\hline 726564 & RED WING & MN & 44.583 & -92.483 & -6 & 239 & II & 12 \\
\hline 726556 & REDWOOD FALLS MUNI & MN & 44.550 & -95.083 & -6 & 312 & II & 12 \\
\hline 726440 & $\begin{array}{l}\text { ROCHESTER } \\
\text { INTERNATIONAL ARPT }\end{array}$ & MN & 43.900 & -92.500 & -6 & 398 & 1 & 24 \\
\hline 727477 & ROSEAU MUNI (AWOS) & $\mathrm{MN}$ & 48.850 & -95.700 & -6 & 323 & II & 12 \\
\hline 727556 & SILVER BAY & $\mathrm{MN}$ & 47.200 & -91.400 & -6 & 331 & III & 12 \\
\hline 726603 & SOUTH ST PAUL MUNI & $\mathrm{MN}$ & 44.850 & -93.150 & -6 & 250 & III & 10 \\
\hline 726550 & ST CLOUD REGIONAL ARPT & $\mathrm{MN}$ & 45.550 & -94.050 & -6 & 311 & $\mathrm{I}$ & 24 \\
\hline 726584 & ST PAUL DOWNTOWN AP & MN & 44.933 & -93.050 & -6 & 220 & II & 12 \\
\hline 727555 & THIEF RIVER(AWOS) & $\mathrm{MN}$ & 48.067 & -96.183 & -6 & 340 & II & 12 \\
\hline 727444 & TWO HARBORS & MN & 47.050 & -91.750 & -6 & 328 & III & 12 \\
\hline 727533 & WHEATON NDB (AWOS) & $\mathrm{MN}$ & 45.700 & -96.500 & -6 & 313 & III & 12 \\
\hline 726576 & WILLMAR & $\mathrm{MN}$ & 45.117 & -95.083 & -6 & 345 & II & 12 \\
\hline 726588 & WINONA MUNI (AWOS) & $\mathrm{MN}$ & 44.083 & -91.700 & -6 & 200 & II & 12 \\
\hline 726587 & WORTHINGTON (AWOS) & $\mathrm{MN}$ & 43.650 & -95.583 & -6 & 480 & II & 12 \\
\hline 723489 & $\begin{array}{l}\text { CAPE GIRARDEAU } \\
\text { MUNICIPAL AP }\end{array}$ & MO & 37.233 & -89.567 & -6 & 103 & II & 12 \\
\hline 724450 & $\begin{array}{l}\text { COLUMBIA REGIONAL } \\
\text { AIRPORT }\end{array}$ & MO & 38.817 & -92.217 & -6 & 272 & 1 & 24 \\
\hline 724454 & FARMINGTON & $\mathrm{MO}$ & 37.767 & -90.400 & -6 & 274 & III & 10 \\
\hline 724457 & FT LNRD WD AAF & $\mathrm{MO}$ & 37.750 & -92.150 & -6 & 351 & II & 12 \\
\hline 724458 & JEFFERSON CITY MEM & $\mathrm{MO}$ & 38.583 & -92.150 & -6 & 167 & II & 12 \\
\hline 723495 & JOPLIN MUNICIPAL AP & $\mathrm{MO}$ & 37.150 & -94.500 & -6 & 297 & II & 12 \\
\hline 724459 & KAISER MEM (AWOS) & $\mathrm{MO}$ & 38.100 & -92.550 & -6 & 265 & II & 12 \\
\hline 724463 & $\begin{array}{l}\text { KANSAS CITY DOWNTOWN } \\
\text { AP }\end{array}$ & MO & 39.117 & -94.600 & -6 & 226 & II & 12 \\
\hline 724460 & KANSAS CITY INT'L ARPT & $\mathrm{MO}$ & 39.300 & -94.717 & -6 & 298 & $\mathrm{I}$ & 24 \\
\hline 724455 & KIRKSVILLE REGIONAL AP & $\mathrm{MO}$ & 40.100 & -92.550 & -6 & 294 & II & 12 \\
\hline 723300 & POPLAR BLUFF(AMOS) & $\mathrm{MO}$ & 36.767 & -90.467 & -6 & 146 & III & 10 \\
\hline 724400 & $\begin{array}{l}\text { SPRINGFIELD REGIONAL } \\
\text { ARPT }\end{array}$ & MO & 37.233 & -93.383 & -6 & 384 & 1 & 24 \\
\hline 724490 & $\begin{array}{l}\text { ST JOSEPH ROSECRANS } \\
\text { MEMORIAL }\end{array}$ & MO & 39.767 & -94.900 & -6 & 247 & II & 12 \\
\hline 724340 & $\begin{array}{l}\text { ST LOUIS LAMBERT INT'L } \\
\text { ARPT }\end{array}$ & MO & 38.750 & -90.367 & -6 & 173 & 1 & 24 \\
\hline 724345 & $\begin{array}{l}\text { ST LOUIS SPIRIT OF ST } \\
\text { LOUIS A }\end{array}$ & MO & 38.650 & -90.650 & -6 & 141 & 1 & 12 \\
\hline 724456 & VICHY ROLLA NATL ARPT & $\mathrm{MO}$ & 38.133 & -91.767 & -6 & 336 & II & 12 \\
\hline
\end{tabular}




\begin{tabular}{|c|c|c|c|c|c|c|c|c|}
\hline USAF & Station Name & State & $\begin{array}{l}\text { Lati- } \\
\text { tude }\end{array}$ & $\begin{array}{l}\text { Longi- } \\
\text { tude }\end{array}$ & $\begin{array}{l}\text { Time } \\
\text { Zone }\end{array}$ & $\begin{array}{c}\text { Eleva- } \\
\text { tion }\end{array}$ & $\begin{array}{l}\text { NSRDB } \\
\text { Class }\end{array}$ & $\begin{array}{l}\text { Pool } \\
\text { Years }\end{array}$ \\
\hline 724467 & WHITEMAN AFB & $\mathrm{MO}$ & 38.717 & -93.550 & -6 & 255 & II & 12 \\
\hline 723306 & COLUMBUS AFB & MS & 33.650 & -88.450 & -6 & 68 & II & 12 \\
\hline 723307 & GOLDEN TRI(AWOS) & MS & 33.450 & -88.583 & -6 & 80 & II & 12 \\
\hline 722356 & GREENVILLE MUNICIPAL & MS & 33.483 & -90.983 & -6 & 42 & II & 12 \\
\hline 722359 & $\begin{array}{l}\text { GREENWOOD LEFLORE } \\
\text { ARPT }\end{array}$ & MS & 33.500 & -90.083 & -6 & 47 & II & 12 \\
\hline 747685 & GULFPORT BILOXI INT & MS & 30.400 & -89.067 & -6 & 9 & II & 12 \\
\hline 722348 & HATTIESBURG LAUREL & MS & 31.467 & -89.333 & -6 & 93 & II & 12 \\
\hline 722350 & $\begin{array}{l}\text { JACKSON INTERNATIONAL } \\
\text { AP }\end{array}$ & MS & 32.317 & -90.083 & -6 & 94 & I & 24 \\
\hline 747686 & KEESLER AFB & MS & 30.417 & -88.917 & -6 & 8 & II & 12 \\
\hline 722358 & MCCOMB PIKE COUNTY AP & MS & 31.233 & -90.467 & -6 & 126 & II & 12 \\
\hline 722340 & MERIDIAN KEY FIELD & MS & 32.333 & -88.750 & -6 & 90 & I & 24 \\
\hline 722345 & MERIDIAN NAAS & MS & 32.550 & -88.567 & -6 & 83 & II & 12 \\
\hline 722357 & NATCHEZ/HARDY(AWOS) & MS & 31.617 & -91.300 & -6 & 83 & II & 12 \\
\hline 723320 & TUPELO C D LEMONS ARPT & MS & 34.267 & -88.767 & -6 & 110 & II & 12 \\
\hline 726770 & $\begin{array}{l}\text { BILLINGS LOGAN INT'L } \\
\text { ARPT }\end{array}$ & MT & 45.800 & -108.550 & -7 & 1087 & I & 24 \\
\hline 726797 & BOZEMAN GALLATIN FIELD & MT & 45.800 & -111.150 & -7 & 1349 & II & 12 \\
\hline 726785 & $\begin{array}{l}\text { BUTTE BERT MOONEY } \\
\text { ARPT }\end{array}$ & MT & 45.950 & -112.500 & -7 & 1689 & II & 12 \\
\hline 727796 & CUT BANK MUNI AP & MT & 48.600 & -112.367 & -7 & 1170 & II & 21 \\
\hline 727680 & GLASGOW INTL ARPT & MT & 48.217 & -106.617 & -7 & 699 & 1 & 24 \\
\hline 726676 & GLENDIVE(AWOS) & MT & 47.133 & -104.800 & -7 & 749 & II & 12 \\
\hline 727750 & GREAT FALLS INTL ARPT & MT & 47.467 & -111.383 & -7 & 1117 & $\mathrm{I}$ & 24 \\
\hline 727770 & HAVRE CITY-COUNTY AP & MT & 48.550 & -109.767 & -7 & 788 & II & 12 \\
\hline 727720 & $\begin{array}{l}\text { HELENA REGIONAL } \\
\text { AIRPORT }\end{array}$ & MT & 46.600 & -111.967 & -7 & 1167 & I & 24 \\
\hline 727790 & $\begin{array}{l}\text { KALISPELL GLACIER PK } \\
\text { INT'L AR }\end{array}$ & MT & 48.317 & -114.250 & -7 & 906 & I & 24 \\
\hline 726776 & $\begin{array}{l}\text { LEWISTOWN MUNICIPAL } \\
\text { ARPT }\end{array}$ & MT & 47.050 & -109.450 & -7 & 1263 & II & 24 \\
\hline 726798 & LIVINGSTON MISSION FIELD & MT & 45.700 & -110.450 & -7 & 1418 & II & 12 \\
\hline 742300 & $\begin{array}{l}\text { MILES CITY MUNICIPAL } \\
\text { ARPT }\end{array}$ & MT & 46.433 & -105.883 & -7 & 801 & II & 22 \\
\hline 727730 & $\begin{array}{l}\text { MISSOULA INTERNATIONAL } \\
\text { AP }\end{array}$ & MT & 46.917 & -114.100 & -7 & 973 & I & 24 \\
\hline 727687 & SIDNEY-RICHLAND & MT & 47.700 & -104.200 & -7 & 605 & II & 12 \\
\hline 727686 & $\begin{array}{l}\text { WOLF POINT INTL [FORT } \\
\text { PECK - SURFRAD] }\end{array}$ & MT & 48.310 & -105.100 & -7 & 634 & II & 12 \\
\hline 723150 & $\begin{array}{l}\text { ASHEVILLE REGIONAL } \\
\text { ARPT }\end{array}$ & $\mathrm{NC}$ & 35.433 & -82.533 & -5 & 652 & I & 24 \\
\hline 723040 & $\begin{array}{l}\text { CAPE HATTERAS NWS } \\
\text { BLDG }\end{array}$ & NC & 35.267 & -75.550 & -5 & 3 & I & 24 \\
\hline 723140 & $\begin{array}{l}\text { CHARLOTTE DOUGLAS INTL } \\
\text { ARPT }\end{array}$ & NC & 35.217 & -80.950 & -5 & 222 & I & 24 \\
\hline 723090 & CHERRY POINT MCAS & $\mathrm{NC}$ & 34.900 & -76.883 & -5 & 11 & II & 12 \\
\hline 723046 & DARE CO RGNL & $\mathrm{NC}$ & 35.917 & -75.700 & -5 & 4 & II & 12 \\
\hline 746943 & $\begin{array}{l}\text { ELIZABETH CITY COAST } \\
\text { GUARD AI [NREL] }\end{array}$ & $\mathrm{NC}$ & 36.300 & -76.250 & -5 & 4 & III & 10 \\
\hline
\end{tabular}




\begin{tabular}{|c|c|c|c|c|c|c|c|c|}
\hline USAF & Station Name & State & $\begin{array}{l}\text { Lati- } \\
\text { tude }\end{array}$ & $\begin{array}{l}\text { Longi- } \\
\text { tude }\end{array}$ & $\begin{array}{l}\text { Time } \\
\text { Zone }\end{array}$ & $\begin{array}{c}\text { Eleva- } \\
\text { tion }\end{array}$ & $\begin{array}{l}\text { NSRDB } \\
\text { Class }\end{array}$ & $\begin{array}{l}\text { Pool } \\
\text { Years }\end{array}$ \\
\hline 723030 & FAYETTEVILLE POPE AFB & NC & 35.167 & -79.017 & -5 & 66 & II & 12 \\
\hline 723035 & FAYETTEVILLE RGNL G & NC & 34.983 & -78.883 & -5 & 59 & II & 12 \\
\hline 746930 & $\begin{array}{l}\text { FORT BRAGG SIMMONS } \\
\text { AAF }\end{array}$ & NC & 35.133 & -78.933 & -5 & 93 & II & 12 \\
\hline 723066 & $\begin{array}{l}\text { GOLDSBORO SEYMOUR } \\
\text { JOHNSON AFB }\end{array}$ & NC & 35.350 & -77.967 & -5 & 33 & II & 12 \\
\hline 723170 & $\begin{array}{l}\text { GREENSBORO PIEDMONT } \\
\text { TRIAD INT }\end{array}$ & NC & 36.100 & -79.950 & -5 & 273 & I & 24 \\
\hline 723145 & HICKORY REGIONAL AP & NC & 35.733 & -81.383 & -5 & 348 & II & 12 \\
\hline 723069 & JACKSONVILLE (AWOS) & NC & 34.833 & -77.617 & -5 & 29 & II & 12 \\
\hline 723067 & KINSTON STALLINGS AFB & $\mathrm{NC}$ & 35.317 & -77.633 & -5 & 29 & II & 12 \\
\hline 723095 & $\begin{array}{l}\text { NEW BERN CRAVEN CO } \\
\text { REGL AP }\end{array}$ & NC & 35.067 & -77.050 & -5 & 5 & II & 12 \\
\hline 723096 & NEW RIVER MCAF & $\mathrm{NC}$ & 34.700 & -77.383 & -5 & 5 & II & 12 \\
\hline 723065 & PITT GREENVILLE ARP & $\mathrm{NC}$ & 35.633 & -77.400 & -5 & 8 & III & 11 \\
\hline 723060 & $\begin{array}{l}\text { RALEIGH DURHAM } \\
\text { INTERNATIONAL }\end{array}$ & $\mathrm{NC}$ & 35.867 & -78.783 & -5 & 127 & 1 & 24 \\
\hline 723068 & ROCKY MOUNT WILSON & $\mathrm{NC}$ & 35.850 & -77.900 & -5 & 50 & II & 12 \\
\hline 723143 & SOUTHERN PINES AWOS & $\mathrm{NC}$ & 35.233 & -79.400 & -5 & 141 & III & 12 \\
\hline 723013 & $\begin{array}{l}\text { WILMINGTON } \\
\text { INTERNATIONAL ARPT }\end{array}$ & NC & 34.267 & -77.900 & -5 & 9 & 1 & 24 \\
\hline 723193 & $\begin{array}{l}\text { WINSTON-SALEM } \\
\text { REYNOLDS AP }\end{array}$ & NC & 36.133 & -80.217 & -5 & 296 & II & 12 \\
\hline 727640 & $\begin{array}{l}\text { BISMARCK MUNICIPAL } \\
\text { ARPT [ISIS] }\end{array}$ & ND & 46.770 & -100.770 & -7 & 502 & I & 24 \\
\hline 727573 & DEVILS LAKE(AWOS) & ND & 48.117 & -98.917 & -6 & 443 & II & 12 \\
\hline 727645 & DICKINSON MUNICIPAL AP & ND & 46.800 & -102.800 & -7 & 788 & II & 12 \\
\hline 727530 & $\begin{array}{l}\text { FARGO HECTOR } \\
\text { INTERNATIONAL AP }\end{array}$ & ND & 46.933 & -96.817 & -6 & 274 & I & 24 \\
\hline 727575 & GRAND FORKS AF & ND & 47.967 & -97.400 & -6 & 276 & II & 12 \\
\hline 727576 & $\begin{array}{l}\text { GRAND FORKS } \\
\text { INTERNATIONAL AP }\end{array}$ & ND & 47.950 & -97.183 & -6 & 256 & II & 12 \\
\hline 727535 & $\begin{array}{l}\text { JAMESTOWN MUNICIPAL } \\
\text { ARPT }\end{array}$ & ND & 46.917 & -98.683 & -6 & 455 & II & 12 \\
\hline 727675 & MINOT AFB & ND & 48.417 & -101.350 & -6 & 497 & II & 12 \\
\hline 727676 & MINOT FAA AP & ND & 48.267 & -101.283 & -6 & 523 & $\mathrm{I}$ & 21 \\
\hline 727670 & $\begin{array}{l}\text { WILLISTON SLOULIN INTL } \\
\text { AP }\end{array}$ & ND & 48.200 & -103.650 & -6 & 580 & I & 12 \\
\hline 725556 & AINSWORTH MUNICIPAL & $\mathrm{NE}$ & 42.583 & -100.000 & -6 & 789 & II & 12 \\
\hline 725635 & ALLIANCE MUNICIPAL & $\mathrm{NE}$ & 42.050 & -102.800 & -7 & 1198 & II & 12 \\
\hline 725515 & BEATRICE MUNICIPAL & $\mathrm{NE}$ & 40.300 & -96.750 & -6 & 403 & III & 11 \\
\hline 725540 & BELLEVUE OFFUTT AFB & $\mathrm{NE}$ & 41.117 & -95.917 & -6 & 319 & II & 12 \\
\hline 725628 & BREWSTER FIELD ARPT & $\mathrm{NE}$ & 40.450 & -99.333 & -6 & 704 & III & 10 \\
\hline 725555 & BROKEN BOW MUNI & $\mathrm{NE}$ & 41.433 & -99.650 & -6 & 776 & II & 12 \\
\hline 725636 & CHADRON MUNICIPAL AP & $\mathrm{NE}$ & 42.833 & -103.083 & -7 & 1011 & II & 12 \\
\hline 725565 & COLUMBUS MUNI & $\mathrm{NE}$ & 41.450 & -97.333 & -6 & 451 & II & 12 \\
\hline 725533 & FALLS CITY/BRENNER & $\mathrm{NE}$ & 40.083 & -95.600 & -6 & 300 & II & 12 \\
\hline 725564 & FREMONT MUNI ARPT & NE & 41.450 & -96.517 & -6 & 379 & III & 10 \\
\hline 725520 & $\begin{array}{l}\text { GRAND ISLAND CENTRAL } \\
\text { NE REGIO }\end{array}$ & NE & 40.967 & -98.317 & -6 & 561 & II & 24 \\
\hline
\end{tabular}




\begin{tabular}{|c|c|c|c|c|c|c|c|c|}
\hline USAF & Station Name & State & $\begin{array}{l}\text { Lati- } \\
\text { tude }\end{array}$ & $\begin{array}{l}\text { Longi- } \\
\text { tude }\end{array}$ & $\begin{array}{l}\text { Time } \\
\text { Zone }\end{array}$ & $\begin{array}{c}\text { Eleva- } \\
\text { tion }\end{array}$ & $\begin{array}{l}\text { NSRDB } \\
\text { Class }\end{array}$ & $\begin{array}{l}\text { Pool } \\
\text { Years }\end{array}$ \\
\hline 725525 & HASTINGS MUNICIPAL & $\mathrm{NE}$ & 40.600 & -98.433 & -6 & 596 & II & 12 \\
\hline 725626 & IMPERIAL FAA AP & NE & 40.517 & -101.617 & -7 & 998 & II & 12 \\
\hline 725526 & KEARNEY MUNI (AWOS) & NE & 40.733 & -99.000 & -6 & 649 & II & 12 \\
\hline 725510 & LINCOLN MUNICIPAL ARPT & $\mathrm{NE}$ & 40.833 & -96.767 & -6 & 357 & II & 12 \\
\hline 725625 & MCCOOK MUNICIPAL & $\mathrm{NE}$ & 40.200 & -100.583 & -6 & 786 & II & 12 \\
\hline 725560 & $\begin{array}{l}\text { NORFOLK KARL STEFAN } \\
\text { MEM ARPT }\end{array}$ & NE & 41.983 & -97.433 & -6 & 472 & I & 24 \\
\hline 725620 & $\begin{array}{l}\text { NORTH PLATTE REGIONAL } \\
\text { AP }\end{array}$ & NE & 41.117 & -100.667 & -6 & 847 & 1 & 24 \\
\hline 725566 & O`NEILL/BAKER FIELD & NE & 42.467 & -98.683 & -6 & 619 & III & 12 \\
\hline 725500 & OMAHA EPPLEY AIRFIELD & $\mathrm{NE}$ & 41.317 & -95.900 & -6 & 299 & $\mathrm{I}$ & 12 \\
\hline 725530 & OMAHA WSFO & $\mathrm{NE}$ & 41.367 & -96.017 & -6 & 399 & III & 13 \\
\hline 725524 & ORD/SHARP FIELD & $\mathrm{NE}$ & 41.617 & -98.950 & -6 & 631 & II & 12 \\
\hline 725660 & $\begin{array}{l}\text { SCOTTSBLUFF W B HEILIG } \\
\text { FIELD }\end{array}$ & NE & 41.867 & -103.600 & -7 & 1202 & 1 & 24 \\
\hline 725610 & SIDNEY MUNICIPAL AP & NE & 41.100 & -102.983 & -7 & 1313 & II & 12 \\
\hline 725527 & TEKAMAH (ASOS) & $\mathrm{NE}$ & 41.767 & -96.167 & -6 & 312 & III & 10 \\
\hline 725670 & VALENTINE MILLER FIELD & $\mathrm{NE}$ & 42.867 & -100.550 & -6 & 789 & 1 & 12 \\
\hline 726160 & BERLIN MUNICIPAL & $\mathrm{NH}$ & 44.583 & -71.183 & -5 & 353 & III & 10 \\
\hline 726050 & $\begin{array}{l}\text { CONCORD MUNICIPAL } \\
\text { ARPT }\end{array}$ & $\mathrm{NH}$ & 43.200 & -71.500 & -5 & 106 & 1 & 24 \\
\hline 726165 & DILLANT HOPKINS & $\mathrm{NH}$ & 42.900 & -72.267 & -5 & 153 & II & 12 \\
\hline 726155 & LACONIA MUNI (AWOS) & $\mathrm{NH}$ & 43.567 & -71.417 & -5 & 166 & II & 12 \\
\hline 726116 & LEBANON MUNICIPAL & $\mathrm{NH}$ & 43.633 & -72.300 & -5 & 182 & II & 12 \\
\hline 743945 & MANCHESTER AIRPORT & $\mathrm{NH}$ & 42.933 & -71.433 & -5 & 69 & II & 12 \\
\hline 726130 & MOUNT WASHINGTON & $\mathrm{NH}$ & 44.267 & -71.300 & -5 & 1910 & II & 12 \\
\hline 726055 & PEASE INTL TRADEPOR & $\mathrm{NH}$ & 43.083 & -70.817 & -5 & 31 & II & 12 \\
\hline 724070 & ATLANTIC CITY INTL AP & $\mathrm{NJ}$ & 39.450 & -74.567 & -5 & 18 & I & 24 \\
\hline 724084 & BELMAR ASC & $\mathrm{NJ}$ & 40.183 & -74.067 & -5 & 26 & III & 12 \\
\hline 724094 & CALDWELL/ESSEX CO. & $\mathrm{NJ}$ & 40.883 & -74.283 & -5 & 53 & II & 12 \\
\hline 745966 & CAPE MAY CO & $\mathrm{NJ}$ & 39.000 & -74.917 & -5 & 7 & III & 12 \\
\hline 724096 & MCGUIRE AFB & $\mathrm{NJ}$ & 40.017 & -74.600 & -5 & 45 & II & 12 \\
\hline 724075 & MILLVILLE MUNICIPAL AP & $\mathrm{NJ}$ & 39.367 & -75.083 & -5 & 21 & II & 12 \\
\hline 725020 & $\begin{array}{l}\text { NEWARK INTERNATIONAL } \\
\text { ARPT }\end{array}$ & NJ & 40.717 & -74.183 & -5 & 3 & I & 24 \\
\hline 725025 & TETERBORO AIRPORT & $\mathrm{NJ}$ & 40.850 & -74.067 & -5 & 3 & II & 12 \\
\hline 724095 & $\begin{array}{l}\text { TRENTON MERCER } \\
\text { COUNTY AP }\end{array}$ & NJ & 40.283 & -74.817 & -5 & 65 & II & 12 \\
\hline 723650 & $\begin{array}{l}\text { ALBUQUERQUE INTL ARPT } \\
\text { [ISIS] }\end{array}$ & NM & 35.040 & -106.620 & -7 & 1619 & 1 & 24 \\
\hline 722687 & $\begin{array}{l}\text { CARLSBAD CAVERN CITY } \\
\text { AIR TERM }\end{array}$ & NM & 32.333 & -104.267 & -7 & 985 & II & 12 \\
\hline 723600 & $\begin{array}{l}\text { CLAYTON MUNICIPAL } \\
\text { AIRPARK }\end{array}$ & NM & 36.450 & -103.150 & -7 & 1512 & II & 12 \\
\hline 722686 & CLOVIS CANNON AFB & NM & 34.383 & -103.317 & -7 & 1309 & II & 12 \\
\hline 722689 & CLOVIS MUNI (AWOS) & NM & 34.433 & -103.083 & -7 & 1284 & III & 12 \\
\hline 722725 & DEMING MUNI & NM & 32.250 & -107.717 & -7 & 1348 & II & 12 \\
\hline 723658 & $\begin{array}{l}\text { FARMINGTON FOUR } \\
\text { CORNERS REGL }\end{array}$ & NM & 36.750 & -108.233 & -7 & 1675 & II & 12 \\
\hline
\end{tabular}




\begin{tabular}{|c|c|c|c|c|c|c|c|c|}
\hline USAF & Station Name & State & $\begin{array}{l}\text { Lati- } \\
\text { tude }\end{array}$ & $\begin{array}{l}\text { Longi- } \\
\text { tude }\end{array}$ & $\begin{array}{l}\text { Time } \\
\text { Zone }\end{array}$ & $\begin{array}{c}\text { Eleva- } \\
\text { tion }\end{array}$ & $\begin{array}{l}\text { NSRDB } \\
\text { Class }\end{array}$ & $\begin{array}{l}\text { Pool } \\
\text { Years }\end{array}$ \\
\hline 723627 & GALLUP SEN CLARKE FLD & NM & 35.517 & -108.783 & -7 & 1971 & I & 12 \\
\hline 747320 & HOLLOMAN AFB & NM & 32.850 & -106.100 & -7 & 1248 & II & 12 \\
\hline 722695 & LAS CRUCES INTL & NM & 32.283 & -106.917 & -7 & 1393 & II & 12 \\
\hline 723677 & $\begin{array}{l}\text { LAS VEGAS MUNICIPAL } \\
\text { ARPT }\end{array}$ & NM & 35.650 & -105.150 & -7 & 2093 & II & 12 \\
\hline 722680 & $\begin{array}{l}\text { ROSWELL INDUSTRIAL AIR } \\
\text { PARK }\end{array}$ & NM & 33.300 & -104.533 & -7 & 1112 & I & 12 \\
\hline 723656 & $\begin{array}{l}\text { SANTA FE COUNTY } \\
\text { MUNICIPAL AP }\end{array}$ & NM & 35.617 & -106.083 & -7 & 1934 & II & 12 \\
\hline 722683 & SIERRA BLANCA RGNL & NM & 33.467 & -105.533 & -7 & 2078 & III & 10 \\
\hline 723663 & TAOS MUNI APT(AWOS) & NM & 36.450 & -105.667 & -7 & 2161 & III & 12 \\
\hline 722710 & $\begin{array}{l}\text { TRUTH OR } \\
\text { CONSEQUENCES MUNI AP }\end{array}$ & NM & 33.233 & -107.267 & -7 & 1478 & II & 12 \\
\hline 723676 & TUCUMCARI FAA AP & NM & 35.183 & -103.600 & -7 & 1235 & II & 21 \\
\hline 725825 & ELKO MUNICIPAL ARPT & NV & 40.833 & -115.800 & -8 & 1548 & II & 24 \\
\hline 724860 & ELY YELLAND FIELD & NV & 39.300 & -114.850 & -8 & 1909 & I & 24 \\
\hline 724885 & FALLON NAAS & NV & 39.417 & -118.717 & -8 & 1199 & II & 12 \\
\hline 723860 & $\begin{array}{l}\text { LAS VEGAS MCCARRAN } \\
\text { INTL AP }\end{array}$ & NV & 36.083 & -115.150 & -8 & 648 & 1 & 24 \\
\hline 725805 & LOVELOCK DERBY FIELD & NV & 40.067 & -118.550 & -8 & 1189 & I & 12 \\
\hline 723870 & $\begin{array}{l}\text { MERCURY DESERT ROCK } \\
\text { AP [SURFRAD] }\end{array}$ & NV & 36.630 & -116.020 & -8 & 935 & I & 12 \\
\hline 723865 & NELLIS AFB & NV & 36.250 & -115.033 & -8 & 573 & II & 12 \\
\hline 724880 & $\begin{array}{l}\text { RENO TAHOE } \\
\text { INTERNATIONAL AP }\end{array}$ & NV & 39.483 & -119.767 & -8 & 1342 & I & 24 \\
\hline 724855 & TONOPAH AIRPORT & NV & 38.067 & -117.083 & -8 & 1655 & $\mathrm{I}$ & 24 \\
\hline 725830 & $\begin{array}{l}\text { WINNEMUCCA MUNICIPAL } \\
\text { ARPT }\end{array}$ & NV & 40.900 & -117.800 & -8 & 1310 & I & 24 \\
\hline 726228 & ADIRONDACK RGNL & NY & 44.383 & -74.200 & -5 & 520 & II & 12 \\
\hline 725180 & ALBANY COUNTY AP & NY & 42.750 & -73.800 & -5 & 84 & I & 24 \\
\hline 725150 & $\begin{array}{l}\text { BINGHAMTON EDWIN A } \\
\text { LINK FIELD }\end{array}$ & NY & 42.200 & -75.983 & -5 & 488 & 1 & 24 \\
\hline 725280 & BUFFALO NIAGARA INTL AP & NY & 42.933 & -78.733 & -5 & 215 & 1 & 24 \\
\hline 725156 & $\begin{array}{l}\text { ELMIRA CORNING } \\
\text { REGIONAL AP }\end{array}$ & NY & 42.167 & -76.900 & -5 & 291 & II & 12 \\
\hline 743700 & FORT DRUM/WHEELER-S & NY & 44.050 & -75.717 & -5 & 211 & II & 12 \\
\hline 725185 & GLENS FALLS AP & NY & 43.350 & -73.617 & -5 & 98 & II & 12 \\
\hline 725035 & $\begin{array}{l}\text { ISLIP LONG ISL } \\
\text { MACARTHUR AP }\end{array}$ & NY & 40.783 & -73.100 & -5 & 26 & I & 12 \\
\hline 725235 & JAMESTOWN (AWOS) & NY & 42.150 & -79.267 & -5 & 525 & II & 12 \\
\hline 726223 & MASSENA AP & NY & 44.933 & -74.850 & -5 & 65 & $\mathrm{I}$ & 24 \\
\hline 725145 & MONTICELLO(AWOS) & NY & 41.700 & -74.800 & -5 & 428 & II & 12 \\
\hline 725033 & $\begin{array}{l}\text { NEW YORK CENTRAL PRK } \\
\text { OBS BELV }\end{array}$ & NY & 40.783 & -73.967 & -5 & 40 & III & 17 \\
\hline 744860 & $\begin{array}{l}\text { NEW YORK J F KENNEDY } \\
\text { INT'L AR }\end{array}$ & NY & 40.650 & -73.800 & -5 & 5 & I & 12 \\
\hline 725030 & $\begin{array}{l}\text { NEW YORK LAGUARDIA } \\
\text { ARPT }\end{array}$ & NY & 40.783 & -73.883 & -5 & 3 & I & 12 \\
\hline 725287 & NIAGARA FALLS AF & NY & 43.100 & -78.950 & -5 & 180 & II & 12 \\
\hline
\end{tabular}




\begin{tabular}{|c|c|c|c|c|c|c|c|c|}
\hline USAF & Station Name & State & $\begin{array}{l}\text { Lati- } \\
\text { tude }\end{array}$ & $\begin{array}{l}\text { Longi- } \\
\text { tude }\end{array}$ & $\begin{array}{l}\text { Time } \\
\text { Zone }\end{array}$ & $\begin{array}{c}\text { Eleva- } \\
\text { tion }\end{array}$ & $\begin{array}{l}\text { NSRDB } \\
\text { Class }\end{array}$ & $\begin{array}{l}\text { Pool } \\
\text { Years }\end{array}$ \\
\hline 725036 & $\begin{array}{l}\text { POUGHKEEPSIE DUTCHESS } \\
\text { CO AP }\end{array}$ & NY & 41.633 & -73.883 & -5 & 47 & II & 12 \\
\hline 744864 & REPUBLIC & NY & 40.717 & -73.417 & -5 & 26 & II & 12 \\
\hline 725290 & $\begin{array}{l}\text { ROCHESTER GREATER } \\
\text { ROCHESTER I }\end{array}$ & NY & 43.117 & -77.683 & -5 & 183 & I & 24 \\
\hline 725038 & STEWART FIELD & NY & 41.500 & -74.100 & -5 & 177 & II & 12 \\
\hline 725190 & $\begin{array}{l}\text { SYRACUSE HANCOCK INT'L } \\
\text { ARPT }\end{array}$ & NY & 43.117 & -76.100 & -5 & 125 & I & 24 \\
\hline 725197 & UTICA ONEIDA COUNTY AP & NY & 43.150 & -75.383 & -5 & 217 & II & 12 \\
\hline 726227 & WATERTOWN AP & NY & 44.000 & -76.017 & -5 & 97 & II & 12 \\
\hline 744865 & $\begin{array}{l}\text { WESTHAMPTON GABRESKI } \\
\text { AP }\end{array}$ & NY & 40.850 & -72.633 & -5 & 20 & II & 12 \\
\hline 725037 & $\begin{array}{l}\text { WHITE PLAINS } \\
\text { WESTCHESTER CO A }\end{array}$ & NY & 41.067 & -73.717 & -5 & 122 & II & 12 \\
\hline 725210 & $\begin{array}{l}\text { AKRON AKRON-CANTON } \\
\text { REG AP }\end{array}$ & $\mathrm{OH}$ & 40.917 & -81.433 & -5 & 368 & I & 24 \\
\hline 725245 & BURKE LAKEFRONT & $\mathrm{OH}$ & 41.517 & -81.683 & -5 & 182 & II & 12 \\
\hline 724297 & $\begin{array}{l}\text { CINCINNATI MUNICIPAL AP } \\
\text { LUNKI }\end{array}$ & $\mathrm{OH}$ & 39.100 & -84.417 & -5 & 149 & II & 12 \\
\hline 725240 & $\begin{array}{l}\text { CLEVELAND HOPKINS INTL } \\
\text { AP }\end{array}$ & $\mathrm{OH}$ & 41.400 & -81.850 & -5 & 235 & I & 24 \\
\hline 724280 & $\begin{array}{l}\text { COLUMBUS PORT } \\
\text { COLUMBUS INTL A }\end{array}$ & $\mathrm{OH}$ & 39.983 & -82.883 & -5 & 247 & I & 24 \\
\hline 724290 & $\begin{array}{l}\text { DAYTON INTERNATIONAL } \\
\text { AIRPORT }\end{array}$ & $\mathrm{OH}$ & 39.900 & -84.217 & -5 & 305 & I & 24 \\
\hline 745700 & $\begin{array}{l}\text { DAYTON WRIGHT } \\
\text { PATTERSON AFB }\end{array}$ & $\mathrm{OH}$ & 39.833 & -84.050 & -5 & 250 & II & 12 \\
\hline 725366 & FINDLAY AIRPORT & $\mathrm{OH}$ & 41.017 & -83.667 & -5 & 244 & II & 12 \\
\hline 725246 & $\begin{array}{l}\text { MANSFIELD LAHM } \\
\text { MUNICIPAL ARPT }\end{array}$ & $\mathrm{OH}$ & 40.817 & -82.517 & -5 & 395 & I & 24 \\
\hline 724288 & OHIO STATE UNIVERSI & $\mathrm{OH}$ & 40.067 & -83.067 & -5 & 283 & II & 12 \\
\hline 725360 & $\begin{array}{l}\text { TOLEDO EXPRESS } \\
\text { AIRPORT }\end{array}$ & $\mathrm{OH}$ & 41.583 & -83.800 & -5 & 204 & I & 24 \\
\hline 725250 & $\begin{array}{l}\text { YOUNGSTOWN REGIONAL } \\
\text { AIRPORT }\end{array}$ & $\mathrm{OH}$ & 41.250 & -80.667 & -5 & 360 & I & 24 \\
\hline 724286 & ZANESVILLE MUNICIPAL AP & $\mathrm{OH}$ & 39.950 & -81.900 & -5 & 268 & II & 12 \\
\hline 723520 & ALTUS AFB & $\mathrm{OK}$ & 34.650 & -99.267 & -6 & 414 & II & 12 \\
\hline 723565 & BARTLESVILLE/PHILLI & OK & 36.767 & -96.017 & -6 & 218 & II & 12 \\
\hline 723526 & CLINTON-SHERMAN & OK & 35.333 & -99.200 & -6 & 586 & III & 10 \\
\hline 723550 & FORT SILL POST FIELD AF & $\mathrm{OK}$ & 34.650 & -98.400 & -6 & 369 & II & 12 \\
\hline 723527 & GAGE AIRPORT & OK & 36.300 & -99.767 & -6 & 668 & II & 12 \\
\hline 723525 & HOBART MUNICIPAL AP & $\mathrm{OK}$ & 35.000 & -99.050 & -6 & 478 & II & 12 \\
\hline 723575 & LAWTON MUNICIPAL & $\mathrm{OK}$ & 34.567 & -98.417 & -6 & 338 & II & 12 \\
\hline 723566 & MCALESTER MUNICIPAL AP & OK & 34.900 & -95.783 & -6 & 232 & II & 12 \\
\hline 723540 & $\begin{array}{l}\text { OKLAHOMA CITY TINKER } \\
\text { AFB }\end{array}$ & OK & 35.417 & -97.383 & -6 & 384 & II & 12 \\
\hline 723530 & $\begin{array}{l}\text { OKLAHOMA CITY WILL } \\
\text { ROGERS WOR }\end{array}$ & OK & 35.383 & -97.600 & -6 & 398 & II & 24 \\
\hline 723544 & OKLAHOMA CITYMILEY & $\mathrm{OK}$ & 35.533 & -97.650 & -6 & 396 & II & 12 \\
\hline
\end{tabular}




\begin{tabular}{|c|c|c|c|c|c|c|c|c|}
\hline USAF & Station Name & State & $\begin{array}{l}\text { Lati- } \\
\text { tude }\end{array}$ & $\begin{array}{l}\text { Longi- } \\
\text { tude }\end{array}$ & $\begin{array}{l}\text { Time } \\
\text { Zone }\end{array}$ & $\begin{array}{c}\text { Eleva- } \\
\text { tion }\end{array}$ & $\begin{array}{l}\text { NSRDB } \\
\text { Class }\end{array}$ & $\begin{array}{l}\text { Pool } \\
\text { Years }\end{array}$ \\
\hline 723546 & $\begin{array}{l}\text { PONCA CITY MUNICIPAL AP } \\
\text { [SGP - ARM] }\end{array}$ & OK & 36.610 & -97.490 & -6 & 318 & II & 12 \\
\hline 723545 & STILLWATER RGNL & $\mathrm{OK}$ & 36.150 & -97.083 & -6 & 308 & II & 12 \\
\hline 723560 & $\begin{array}{l}\text { TULSA INTERNATIONAL } \\
\text { AIRPORT }\end{array}$ & OK & 36.200 & -95.883 & -6 & 198 & II & 24 \\
\hline 723535 & VANCE AFB & $\mathrm{OK}$ & 36.333 & -97.917 & -6 & 408 & II & 12 \\
\hline 727910 & $\begin{array}{l}\text { ASTORIA REGIONAL } \\
\text { AIRPORT }\end{array}$ & OR & 46.150 & -123.883 & -8 & 3 & II & 24 \\
\hline 726959 & AURORA STATE & OR & 45.250 & -122.767 & -8 & 60 & III & 11 \\
\hline 726886 & BAKER MUNICIPAL AP & OR & 44.833 & -117.817 & -8 & 1027 & II & 12 \\
\hline 726830 & $\begin{array}{l}\text { BURNS MUNICIPAL ARPT } \\
\text { [UO] }\end{array}$ & OR & 43.520 & -119.020 & -8 & 1271 & II & 21 \\
\hline 726945 & CORVALLIS MUNI & OR & 44.483 & -123.283 & -8 & 77 & II & 12 \\
\hline 726930 & $\begin{array}{l}\text { EUGENE MAHLON SWEET } \\
\text { ARPT [UO] }\end{array}$ & OR & 44.050 & -123.070 & -8 & 109 & I & 24 \\
\hline 725895 & $\begin{array}{l}\text { KLAMATH FALLS INTL AP } \\
\text { [UO] }\end{array}$ & OR & 42.220 & -121.740 & -8 & 1220 & II & 12 \\
\hline 726884 & LA GRANDE MUNI AP & OR & 45.283 & -118.000 & -8 & 827 & II & 12 \\
\hline 725976 & LAKEVIEW (AWOS) & OR & 42.167 & -120.400 & -8 & 1441 & II & 12 \\
\hline 725970 & $\begin{array}{l}\text { MEDFORD ROGUE VALLEY } \\
\text { INTL AP [ASHLAND - UO] }\end{array}$ & OR & 42.190 & -122.700 & -8 & 595 & I & 24 \\
\hline 726917 & $\begin{array}{l}\text { NORTH BEND MUNI } \\
\text { AIRPORT }\end{array}$ & OR & 43.417 & -124.250 & -8 & 2 & II & 24 \\
\hline 726880 & $\begin{array}{l}\text { PENDLETON E OR } \\
\text { REGIONAL AP }\end{array}$ & OR & 45.700 & -118.833 & -8 & 452 & I & 24 \\
\hline 726980 & $\begin{array}{l}\text { PORTLAND INTERNATIONAL } \\
\text { AP }\end{array}$ & OR & 45.600 & -122.617 & -8 & 6 & I & 24 \\
\hline 726986 & PORTLAND/HILLSBORO & OR & 45.533 & -122.950 & -8 & 62 & II & 12 \\
\hline 726985 & PORTLAND/TROUTDALE & OR & 45.550 & -122.400 & -8 & 11 & II & 12 \\
\hline 726835 & REDMOND ROBERTS FIELD & OR & 44.250 & -121.167 & -8 & 933 & II & 24 \\
\hline 726904 & ROSEBURG REGIONAL AP & OR & 43.233 & -123.350 & -8 & 160 & II & 12 \\
\hline 726940 & SALEM MCNARY FIELD & OR & 44.900 & -123.000 & -8 & 60 & 1 & 24 \\
\hline 725975 & SEXTON SUMMIT & OR & 42.600 & -123.367 & -8 & 1168 & II & 12 \\
\hline 725170 & $\begin{array}{l}\text { ALLENTOWN LEHIGH } \\
\text { VALLEY INTL }\end{array}$ & PA & 40.650 & -75.450 & -5 & 119 & I & 24 \\
\hline 725126 & ALTOONA BLAIR CO ARPT & PA & 40.300 & -78.317 & -5 & 451 & II & 12 \\
\hline 725266 & BRADFORD REGIONAL AP & PA & 41.800 & -78.633 & -5 & 645 & I & 24 \\
\hline 725124 & BUTLER CO. (AWOS) & PA & 40.783 & -79.950 & -5 & 380 & III & 12 \\
\hline 725125 & DUBOIS FAA AP & PA & 41.183 & -78.900 & -5 & 553 & II & 12 \\
\hline 725260 & ERIE INTERNATIONAL AP & PA & 42.083 & -80.183 & -5 & 222 & 1 & 24 \\
\hline 725267 & FRANKLIN & PA & 41.383 & -79.867 & -5 & 470 & II & 12 \\
\hline 725118 & $\begin{array}{l}\text { HARRISBURG CAPITAL CITY } \\
\text { ARPT }\end{array}$ & PA & 40.217 & -76.850 & -5 & 104 & II & 24 \\
\hline 725127 & $\begin{array}{l}\text { JOHNSTOWN CAMBRIA } \\
\text { COUNTY AP }\end{array}$ & PA & 40.317 & -78.833 & -5 & 695 & II & 12 \\
\hline 725116 & LANCASTER & PA & 40.117 & -76.300 & -5 & 126 & II & 12 \\
\hline 725115 & $\begin{array}{l}\text { MIDDLETOWN } \\
\text { HARRISBURG INTL AP }\end{array}$ & PA & 40.200 & -76.767 & -5 & 92 & I & 12 \\
\hline 724080 & $\begin{array}{l}\text { PHILADELPHIA } \\
\text { INTERNATIONAL AP }\end{array}$ & PA & 39.867 & -75.233 & -5 & 2 & I & 24 \\
\hline
\end{tabular}




\begin{tabular}{|c|c|c|c|c|c|c|c|c|}
\hline USAF & Station Name & State & $\begin{array}{l}\text { Lati- } \\
\text { tude }\end{array}$ & $\begin{array}{l}\text { Longi- } \\
\text { tude }\end{array}$ & $\begin{array}{l}\text { Time } \\
\text { Zone }\end{array}$ & $\begin{array}{c}\text { Eleva- } \\
\text { tion }\end{array}$ & $\begin{array}{l}\text { NSRDB } \\
\text { Class }\end{array}$ & $\begin{array}{l}\text { Pool } \\
\text { Years }\end{array}$ \\
\hline 724085 & $\begin{array}{l}\text { PHILADELPHIA NE } \\
\text { PHILADELPHIA }\end{array}$ & PA & 40.083 & -75.017 & -5 & 30 & II & 12 \\
\hline 725205 & $\begin{array}{l}\text { PITTSBURGH ALLEGHENY } \\
\text { CO AP }\end{array}$ & PA & 40.350 & -79.917 & -5 & 380 & II & 12 \\
\hline 725200 & $\begin{array}{l}\text { PITTSBURGH } \\
\text { INTERNATIONAL AP }\end{array}$ & PA & 40.500 & -80.233 & -5 & 350 & I & 24 \\
\hline 725103 & READING SPAATZ FIELD & PA & 40.367 & -75.967 & -5 & 104 & II & 12 \\
\hline 725128 & $\begin{array}{l}\text { STATE COLLEGE [PENN } \\
\text { STATE - SURFRAD] }\end{array}$ & PA & 40.720 & -77.930 & -5 & 376 & II & 12 \\
\hline 725117 & WASHINGTON (AWOS) & PA & 40.133 & -80.283 & -5 & 361 & II & 12 \\
\hline 725130 & $\begin{array}{l}\text { WILKES-BARRE SCRANTON } \\
\text { INTL AP }\end{array}$ & PA & 41.333 & -75.733 & -5 & 284 & I & 24 \\
\hline 725140 & $\begin{array}{l}\text { WILLIAMSPORT REGIONAL } \\
\text { AP }\end{array}$ & PA & 41.250 & -76.917 & -5 & 158 & 1 & 24 \\
\hline 724086 & WILLOW GROVE NAS & PA & 40.200 & -75.150 & -5 & 102 & II & 12 \\
\hline 785140 & AQUADILLA/BORINQUEN & PR & 18.500 & -67.133 & -4 & 72 & II & 12 \\
\hline 785145 & EUGENIO MARIA DE HO & PR & 18.250 & -67.150 & -4 & 9 & II & 12 \\
\hline 785203 & MERCEDITA & PR & 18.000 & -66.550 & -4 & 8 & II & 12 \\
\hline 785350 & ROOSEVELT ROADS & PR & 18.250 & -65.633 & -4 & 12 & III & 10 \\
\hline 785260 & SAN JUAN INTL ARPT & PR & 18.417 & -66.000 & -4 & 19 & II & 24 \\
\hline 785263 & $\begin{array}{l}\text { SAN JUAN L M MARIN INTL } \\
\text { AP }\end{array}$ & PR & 18.433 & -66.000 & -4 & 3 & III & 10 \\
\hline 725058 & BLOCK ISLAND STATE ARPT & $\mathrm{RI}$ & 41.167 & -71.583 & -5 & 34 & II & 12 \\
\hline 725054 & PAWTUCKET (AWOS) & $\mathrm{RI}$ & 41.917 & -71.500 & -5 & 134 & II & 12 \\
\hline 725070 & $\begin{array}{l}\text { PROVIDENCE T F GREEN } \\
\text { STATE AR }\end{array}$ & $\mathrm{RI}$ & 41.717 & -71.433 & -5 & 16 & 1 & 24 \\
\hline 723125 & ANDERSON COUNTY AP & SC & 34.500 & -82.717 & -5 & 232 & II & 12 \\
\hline 722085 & BEAUFORT MCAS & $\mathrm{SC}$ & 32.483 & -80.717 & -5 & 10 & II & 12 \\
\hline 722080 & CHARLESTON INTL ARPT & SC & 32.900 & -80.033 & -5 & 12 & I & 24 \\
\hline 723100 & COLUMBIA METRO ARPT & $\mathrm{SC}$ & 33.950 & -81.117 & -5 & 65 & I & 24 \\
\hline 723106 & FLORENCE REGIONAL AP & SC & 34.183 & -79.733 & -5 & 44 & II & 12 \\
\hline 723119 & $\begin{array}{l}\text { GREENVILLE DOWNTOWN } \\
\text { AP }\end{array}$ & SC & 34.850 & -82.350 & -5 & 319 & II & 12 \\
\hline 723120 & $\begin{array}{l}\text { GREER GREENV'L- } \\
\text { SPARTANBRG AP }\end{array}$ & SC & 34.900 & -82.217 & -5 & 292 & I & 24 \\
\hline 747910 & MYRTLE BEACH AFB & SC & 33.683 & -78.933 & -5 & 8 & II & 12 \\
\hline 747915 & $\begin{array}{l}\text { NORTH MYRTLE BEACH } \\
\text { GRAND STRA }\end{array}$ & SC & 33.817 & -78.717 & -5 & 10 & II & 12 \\
\hline 747900 & SUMTER SHAW AFB & SC & 33.967 & -80.467 & -5 & 74 & II & 12 \\
\hline 726590 & $\begin{array}{l}\text { ABERDEEN REGIONAL } \\
\text { ARPT }\end{array}$ & SD & 45.450 & -98.417 & -6 & 398 & I & 12 \\
\hline 726515 & BROOKINGS (AWOS) & SD & 44.300 & -96.817 & -6 & 502 & II & 12 \\
\hline 726525 & CHAN GURNEY MUNI & SD & 42.917 & -97.383 & -6 & 408 & II & 12 \\
\hline 726625 & ELLSWORTH AFB & SD & 44.150 & -103.100 & -7 & 980 & II & 12 \\
\hline 726540 & HURON REGIONAL ARPT & SD & 44.400 & -98.217 & -6 & 390 & I & 24 \\
\hline 726545 & MITCHELL (AWOS) & SD & 43.767 & -98.033 & -6 & 397 & II & 12 \\
\hline 726685 & MOBRIDGE & SD & 45.533 & -100.433 & -7 & 508 & II & 12 \\
\hline 726686 & PIERRE MUNICIPAL AP & SD & 44.383 & -100.283 & -7 & 528 & 1 & 24 \\
\hline 726620 & $\begin{array}{l}\text { RAPID CITY REGIONAL } \\
\text { ARPT }\end{array}$ & SD & 44.050 & -103.050 & -7 & 963 & I & 24 \\
\hline
\end{tabular}




\begin{tabular}{|c|c|c|c|c|c|c|c|c|}
\hline USAF & Station Name & State & $\begin{array}{l}\text { Lati- } \\
\text { tude }\end{array}$ & $\begin{array}{l}\text { Longi- } \\
\text { tude }\end{array}$ & $\begin{array}{l}\text { Time } \\
\text { Zone }\end{array}$ & $\begin{array}{c}\text { Eleva- } \\
\text { tion }\end{array}$ & $\begin{array}{l}\text { NSRDB } \\
\text { Class }\end{array}$ & $\begin{array}{l}\text { Pool } \\
\text { Years }\end{array}$ \\
\hline 726510 & SIOUX FALLS FOSS FIELD & SD & 43.583 & -96.750 & -6 & 433 & 1 & 24 \\
\hline 726546 & $\begin{array}{l}\text { WATERTOWN MUNICIPAL } \\
\text { AP }\end{array}$ & SD & 44.933 & -97.150 & -6 & 532 & II & 12 \\
\hline 723183 & BRISTOL TRI CITY AIRPORT & TN & 36.467 & -82.400 & -5 & 457 & I & 24 \\
\hline 723240 & $\begin{array}{l}\text { CHATTANOOGA LOVELL } \\
\text { FIELD AP }\end{array}$ & $\mathrm{TN}$ & 35.033 & -85.200 & -5 & 204 & 1 & 24 \\
\hline 723265 & CROSSVILLE MEMORIAL AP & TN & 35.950 & -85.083 & -6 & 569 & II & 12 \\
\hline 723347 & DYERSBURG MUNICIPAL AP & TN & 36.017 & -89.400 & -6 & 103 & II & 12 \\
\hline 723346 & $\begin{array}{l}\text { JACKSON MCKELLAR-SIPES } \\
\text { REGL A }\end{array}$ & $\mathrm{TN}$ & 35.600 & -88.917 & -6 & 132 & II & 12 \\
\hline 723260 & $\begin{array}{l}\text { KNOXVILLE MCGHEE } \\
\text { TYSON AP }\end{array}$ & TN & 35.817 & -83.983 & -5 & 293 & 1 & 24 \\
\hline 723340 & $\begin{array}{l}\text { MEMPHIS INTERNATIONAL } \\
\text { AP }\end{array}$ & $\mathrm{TN}$ & 35.067 & -89.983 & -6 & 81 & I & 24 \\
\hline 723270 & $\begin{array}{l}\text { NASHVILLE } \\
\text { INTERNATIONAL AP }\end{array}$ & $\mathrm{TN}$ & 36.117 & -86.683 & -6 & 177 & 1 & 24 \\
\hline 690190 & ABILENE DYESS AFB & TX & 32.433 & -99.850 & -6 & 545 & II & 12 \\
\hline 722660 & ABILENE REGIONAL AP [UT] & TX & 32.470 & -99.710 & -6 & 530 & $\mathrm{I}$ & 24 \\
\hline 722517 & ALICE INTL AP & TX & 27.733 & -98.033 & -6 & 53 & II & 12 \\
\hline 723630 & $\begin{array}{l}\text { AMARILLO INTERNATIONAL } \\
\text { AP [CANYON - UT] }\end{array}$ & TX & 34.990 & -101.900 & -6 & 1068 & II & 24 \\
\hline 722540 & $\begin{array}{l}\text { AUSTIN MUELLER } \\
\text { MUNICIPAL AP [UT] }\end{array}$ & $\mathrm{TX}$ & 30.290 & -97.740 & -6 & 213 & I & 12 \\
\hline 722500 & $\begin{array}{l}\text { BROWNSVILLE S PADRE ISL } \\
\text { INTL }\end{array}$ & $\mathrm{TX}$ & 25.900 & -97.433 & -6 & 6 & I & 24 \\
\hline 722544 & CAMP MABRY & TX & 30.317 & -97.767 & -6 & 198 & III & 16 \\
\hline 723604 & CHILDRESS MUNICIPAL AP & $\mathrm{TX}$ & 34.433 & -100.283 & -6 & 595 & II & 12 \\
\hline 722445 & $\begin{array}{l}\text { COLLEGE STATION } \\
\text { EASTERWOOD FL }\end{array}$ & $\mathrm{TX}$ & 30.583 & -96.367 & -6 & 96 & II & 12 \\
\hline 722510 & $\begin{array}{l}\text { CORPUS CHRISTI INTL } \\
\text { ARPT [UT] }\end{array}$ & $\mathrm{TX}$ & 27.880 & -97.630 & -6 & 6 & 1 & 24 \\
\hline 722515 & CORPUS CHRISTI NAS & $\mathrm{TX}$ & 27.683 & -97.283 & -6 & 6 & II & 12 \\
\hline 722526 & COTULLA FAA AP & $\mathrm{TX}$ & 28.450 & -99.217 & -6 & 141 & II & 12 \\
\hline 722587 & COX FLD & $\mathrm{TX}$ & 33.633 & -95.450 & -6 & 171 & III & 12 \\
\hline 722636 & DALHART MUNICIPAL AP & $\mathrm{TX}$ & 36.017 & -102.550 & -6 & 1216 & II & 12 \\
\hline 722583 & DALLAS LOVE FIELD & $\mathrm{TX}$ & 32.850 & -96.850 & -6 & 134 & II & 12 \\
\hline 722598 & DALLAS/ADDISON ARPT & $\mathrm{TX}$ & 32.967 & -96.833 & -6 & 196 & II & 12 \\
\hline 722599 & DALLAS/REDBIRD ARPT & TX & 32.683 & -96.867 & -6 & 201 & II & 12 \\
\hline 722590 & $\begin{array}{l}\text { DALLAS-FORT WORTH INTL } \\
\text { AP }\end{array}$ & $\mathrm{TX}$ & 32.900 & -97.017 & -6 & 171 & 1 & 24 \\
\hline 722610 & DEL RIO [UT] & $\mathrm{TX}$ & 29.380 & -100.910 & -6 & 308 & II & 12 \\
\hline 722615 & DEL RIO LAUGHLIN AFB & $\mathrm{TX}$ & 29.367 & -100.783 & -6 & 327 & II & 12 \\
\hline 722577 & DRAUGHON MILLER CEN & $\mathrm{TX}$ & 31.150 & -97.400 & -6 & 213 & II & 12 \\
\hline 722700 & $\begin{array}{l}\text { EL PASO INTERNATIONAL } \\
\text { AP [UT] }\end{array}$ & $\mathrm{TX}$ & 31.770 & -106.500 & -7 & 1186 & 1 & 24 \\
\hline 722570 & FORT HOOD & TX & 31.133 & -97.717 & -6 & 280 & II & 12 \\
\hline 722594 & FORT WORTH ALLIANCE & $\mathrm{TX}$ & 32.983 & -97.317 & -6 & 226 & II & 12 \\
\hline 722596 & FORT WORTH MEACHAM & $\mathrm{TX}$ & 32.817 & -97.367 & -6 & 209 & II & 12 \\
\hline 722595 & FORT WORTH NAS & TX & 32.767 & -97.450 & -6 & 185 & II & 12 \\
\hline 722420 & GALVESTON/SCHOLES & $\mathrm{TX}$ & 29.300 & -94.800 & -6 & 16 & II & 12 \\
\hline
\end{tabular}




\begin{tabular}{|c|c|c|c|c|c|c|c|c|}
\hline USAF & Station Name & State & $\begin{array}{l}\text { Lati- } \\
\text { tude }\end{array}$ & $\begin{array}{l}\text { Longi- } \\
\text { tude }\end{array}$ & $\begin{array}{l}\text { Time } \\
\text { Zone }\end{array}$ & $\begin{array}{c}\text { Eleva- } \\
\text { tion }\end{array}$ & $\begin{array}{l}\text { NSRDB } \\
\text { Class }\end{array}$ & $\begin{array}{l}\text { Pool } \\
\text { Years }\end{array}$ \\
\hline 722547 & GEORGETOWN (AWOS) & TX & 30.683 & -97.683 & -6 & 240 & III & 12 \\
\hline 722588 & GREENVILLE/MAJORS & TX & 33.067 & -96.067 & -6 & 163 & II & 12 \\
\hline 722505 & $\begin{array}{l}\text { HARLINGEN RIO GRANDE } \\
\text { VALLEY I }\end{array}$ & $\mathrm{TX}$ & 26.233 & -97.650 & -6 & 10 & II & 12 \\
\hline 722533 & HONDO MUNICIPAL AP & TX & 29.367 & -99.167 & -6 & 280 & III & 10 \\
\hline 722430 & $\begin{array}{l}\text { HOUSTON BUSH } \\
\text { INTERCONTINENTAL }\end{array}$ & $\mathrm{TX}$ & 30.000 & -95.367 & -6 & 29 & I & 24 \\
\hline 722436 & $\begin{array}{l}\text { HOUSTON ELLINGTON AFB } \\
\text { [CLEAR LAKE - UT] }\end{array}$ & $\mathrm{TX}$ & 29.570 & -95.090 & -6 & 6 & II & 12 \\
\hline 722435 & $\begin{array}{l}\text { HOUSTON WILLIAM P } \\
\text { HOBBY AP }\end{array}$ & $\mathrm{TX}$ & 29.650 & -95.283 & -6 & 13 & II & 12 \\
\hline 722429 & HOUSTON/D.W. HOOKS & TX & 30.067 & -95.550 & -6 & 46 & II & 12 \\
\hline 722575 & KILLEEN MUNI (AWOS) & TX & 31.083 & -97.683 & -6 & 258 & II & 12 \\
\hline 722516 & KINGSVILLE & $\mathrm{TX}$ & 27.500 & -97.817 & -6 & 17 & II & 12 \\
\hline 722520 & LAREDO INTL AP [UT] & $T X$ & 27.570 & -99.490 & -6 & 142 & II & 12 \\
\hline 722470 & $\begin{array}{l}\text { LONGVIEW GREGG } \\
\text { COUNTY AP [OVERTON - } \\
\text { UT] }\end{array}$ & $\mathrm{TX}$ & 32.290 & -94.980 & -6 & 146 & II & 12 \\
\hline 722670 & $\begin{array}{l}\text { LUBBOCK INTERNATIONAL } \\
\text { AP }\end{array}$ & $\mathrm{TX}$ & 33.667 & -101.817 & -6 & 992 & I & 24 \\
\hline 722446 & LUFKIN ANGELINA CO & TX & 31.233 & -94.750 & -6 & 86 & $\mathrm{I}$ & 24 \\
\hline 722640 & MARFA AP & $\mathrm{TX}$ & 30.367 & -104.017 & -6 & 1473 & III & 10 \\
\hline 722563 & MC GREGOR (AWOS) & $\mathrm{TX}$ & 31.483 & -97.317 & -6 & 180 & III & 12 \\
\hline 722506 & $\begin{array}{l}\text { MCALLEN MILLER INTL AP } \\
\text { [EDINBURG - UT] }\end{array}$ & $\mathrm{TX}$ & 26.310 & -98.170 & -6 & 30 & II & 12 \\
\hline 722650 & $\begin{array}{l}\text { MIDLAND INTERNATIONAL } \\
\text { AP }\end{array}$ & $\mathrm{TX}$ & 31.950 & -102.183 & -6 & 872 & I & 24 \\
\hline 722597 & $\begin{array}{l}\text { MINERAL WELLS } \\
\text { MUNICIPAL AP }\end{array}$ & $\mathrm{TX}$ & 32.783 & -98.067 & -6 & 284 & II & 12 \\
\hline 722499 & NACOGDOCHES (AWOS) & TX & 31.583 & -94.717 & -6 & 108 & III & 12 \\
\hline 722555 & PALACIOS MUNICIPAL AP & $\mathrm{TX}$ & 28.717 & -96.250 & -6 & 5 & II & 12 \\
\hline 722410 & $\begin{array}{l}\text { PORT ARTHUR JEFFERSON } \\
\text { COUNTY }\end{array}$ & $\mathrm{TX}$ & 29.950 & -94.017 & -6 & 5 & I & 24 \\
\hline 722536 & RANDOLPH AFB & $\mathrm{TX}$ & 29.533 & -98.283 & -6 & 232 & II & 12 \\
\hline 722576 & ROBERT GRAY AAF & $\mathrm{TX}$ & 31.067 & -97.833 & -6 & 312 & II & 12 \\
\hline 722524 & ROCKPORT/ARANSAS CO & $\mathrm{TX}$ & 28.083 & -97.050 & -6 & 8 & II & 12 \\
\hline 722630 & SAN ANGELO MATHIS FIELD & $\mathrm{TX}$ & 31.350 & -100.500 & -6 & 584 & I & 24 \\
\hline 722530 & SAN ANTONIO INTL AP & $\mathrm{TX}$ & 29.533 & -98.467 & -6 & 247 & 1 & 24 \\
\hline 722535 & $\begin{array}{l}\text { SAN ANTONIO KELLY FIELD } \\
\text { AFB }\end{array}$ & $\mathrm{TX}$ & 29.383 & -98.583 & -6 & 208 & II & 12 \\
\hline 722523 & SAN ANTONIO/STINSON & $\mathrm{TX}$ & 29.333 & -98.467 & -6 & 176 & III & 10 \\
\hline 722448 & TYLER/POUNDS FLD & $\mathrm{TX}$ & 32.350 & -95.400 & -6 & 166 & II & 12 \\
\hline 722550 & VICTORIA REGIONAL AP & $\mathrm{TX}$ & 28.867 & -96.933 & -6 & 35 & $\mathrm{I}$ & 24 \\
\hline 722560 & WACO REGIONAL AP & $\mathrm{TX}$ & 31.617 & -97.233 & -6 & 152 & 1 & 24 \\
\hline 723510 & $\begin{array}{l}\text { WICHITA FALLS MUNICIPAL } \\
\text { ARPT }\end{array}$ & TX & 33.983 & 500 & -6 & 314 & II & 24 \\
\hline 722656 & WINK WINKLER COUNTY AP & $\mathrm{TX}$ & 31.783 & -103.200 & -6 & 856 & II & 12 \\
\hline 724723 & BLANDING & UT & 37.617 & -109.483 & -7 & 1841 & II & 12 \\
\hline 724756 & BRYCE CNYN FAA AP & UT & 37.700 & -112.150 & -7 & 2312 & II & 12 \\
\hline
\end{tabular}




\begin{tabular}{|c|c|c|c|c|c|c|c|c|}
\hline USAF & Station Name & State & $\begin{array}{l}\text { Lati- } \\
\text { tude }\end{array}$ & $\begin{array}{l}\text { Longi- } \\
\text { tude }\end{array}$ & $\begin{array}{l}\text { Time } \\
\text { Zone }\end{array}$ & $\begin{array}{c}\text { Eleva- } \\
\text { tion }\end{array}$ & $\begin{array}{c}\text { NSRDB } \\
\text { Class }\end{array}$ & $\begin{array}{l}\text { Pool } \\
\text { Years }\end{array}$ \\
\hline 724755 & CEDAR CITY MUNICIPAL AP & UT & 37.700 & -113.100 & -7 & 1703 & I & 24 \\
\hline 724795 & DELTA & UT & 39.333 & -112.583 & -7 & 1414 & II & 12 \\
\hline 724735 & HANKSVILLE & UT & 38.367 & -110.717 & -7 & 1313 & II & 12 \\
\hline 724776 & MOAB/CANYONLANDS [UO] & UT & 38.580 & -109.540 & -7 & 1000 & III & 10 \\
\hline 725755 & OGDEN HILL AFB & UT & 41.117 & -111.967 & -7 & 1459 & II & 12 \\
\hline 725750 & OGDEN HINKLEY AIRPORT & UT & 41.200 & -112.017 & -7 & 1362 & II & 12 \\
\hline 725724 & PROVO MUNI (AWOS) & UT & 40.217 & -111.717 & -7 & 1369 & II & 12 \\
\hline 724754 & SAINT GEORGE (AWOS) & UT & 37.083 & -113.600 & -7 & 896 & II & 12 \\
\hline 725720 & $\begin{array}{l}\text { SALT LAKE CITY INT'L ARPT } \\
\text { [ISIS] }\end{array}$ & UT & 40.770 & -111.970 & -7 & 1288 & 1 & 24 \\
\hline 725705 & VERNAL & UT & 40.433 & -109.517 & -7 & 1608 & II & 12 \\
\hline 725810 & $\begin{array}{l}\text { WENDOVER USAF } \\
\text { AUXILIARY FIELD }\end{array}$ & UT & 40.717 & -114.033 & -8 & 1291 & II & 12 \\
\hline 724058 & ABINGDON & VA & 36.683 & -82.033 & -5 & 631 & III & 10 \\
\hline 724016 & CHARLOTTESVILLE FAA & VA & 38.133 & -78.450 & -5 & 190 & II & 12 \\
\hline 724106 & DANVILLE FAA AP & VA & 36.567 & -79.333 & -5 & 176 & II & 12 \\
\hline 724037 & DAVISON AAF & VA & 38.717 & -77.183 & -5 & 27 & II & 12 \\
\hline 724014 & DINWIDDIE CO & VA & 37.183 & -77.517 & -5 & 60 & III & 12 \\
\hline 724017 & FARMVILLE & VA & 37.350 & -78.433 & -5 & 125 & III & 11 \\
\hline 723083 & FRANKLIN NAAS & VA & 36.700 & -76.900 & -5 & 12 & III & 11 \\
\hline 724107 & HILLSVILLE & VA & 36.767 & -80.817 & -5 & 834 & III & 11 \\
\hline 724115 & HOT SPRINGS/INGALLS & VA & 37.950 & -79.833 & -5 & 1156 & III & 12 \\
\hline 745980 & LANGLEY AFB & VA & 37.083 & -76.350 & -5 & 3 & II & 12 \\
\hline 724055 & LEESBURG/GODFREY & VA & 39.083 & -77.567 & -5 & 119 & III & 11 \\
\hline 724100 & $\begin{array}{l}\text { LYNCHBURG REGIONAL } \\
\text { ARPT }\end{array}$ & VA & 37.333 & -79.200 & -5 & 286 & I & 24 \\
\hline 724036 & MANASSAS MUNI(AWOS) & VA & 38.717 & -77.517 & -5 & 59 & III & 12 \\
\hline 724056 & MARION / WYTHEVILLE & VA & 36.900 & -81.350 & -5 & 780 & III & 10 \\
\hline 745985 & MARTINSVILLE & VA & 36.633 & -80.017 & -5 & 287 & III & 10 \\
\hline 724026 & MELFA/ACCOMACK ARPT & VA & 37.650 & -75.767 & -5 & 15 & III & 11 \\
\hline 723086 & NEWPORT NEWS & VA & 37.133 & -76.500 & -5 & 13 & II & 12 \\
\hline 723080 & $\begin{array}{l}\text { NORFOLK INTERNATIONAL } \\
\text { AP }\end{array}$ & VA & 36.900 & -76.200 & -5 & 7 & I & 24 \\
\hline 723085 & NORFOLK NAS & VA & 36.950 & -76.283 & -5 & 10 & II & 12 \\
\hline 723075 & OCEANA NAS & VA & 36.817 & -76.033 & -5 & 8 & II & 12 \\
\hline 724116 & PULASKI & VA & 37.133 & -80.683 & -5 & 642 & III & 11 \\
\hline 724035 & QUANTICO MCAS & VA & 38.500 & -77.300 & -5 & 4 & II & 12 \\
\hline 724010 & $\begin{array}{l}\text { RICHMOND } \\
\text { INTERNATIONAL AP }\end{array}$ & VA & 37.517 & -77.317 & -5 & 50 & 1 & 24 \\
\hline 724110 & ROANOKE REGIONAL AP & VA & 37.317 & -79.967 & -5 & 350 & 1 & 24 \\
\hline 724033 & SHANNON ARPT & VA & 38.267 & -77.450 & -5 & 26 & III & 11 \\
\hline 724105 & STAUNTON/SHENANDOAH & VA & 38.267 & -78.900 & -5 & 366 & II & 12 \\
\hline 724113 & VIRGINIA TECH ARPT & VA & 37.217 & -80.417 & -5 & 650 & III & 11 \\
\hline 724030 & $\begin{array}{l}\text { WASHINGTON DC DULLES } \\
\text { INT'L AR [STERLING - ISIS] }\end{array}$ & VA & 38.980 & -77.470 & -5 & 82 & 1 & 24 \\
\hline 724050 & $\begin{array}{l}\text { WASHINGTON DC REAGAN } \\
\text { AP }\end{array}$ & VA & 38.867 & -77.033 & -5 & 3 & I & 12 \\
\hline 724053 & WINCHESTER RGNL & VA & 39.150 & -78.150 & -5 & 222 & III & 11 \\
\hline
\end{tabular}




\begin{tabular}{|c|c|c|c|c|c|c|c|c|}
\hline USAF & Station Name & State & $\begin{array}{l}\text { Lati- } \\
\text { tude }\end{array}$ & $\begin{array}{l}\text { Longi- } \\
\text { tude }\end{array}$ & $\begin{array}{l}\text { Time } \\
\text { Zone }\end{array}$ & $\begin{array}{c}\text { Eleva- } \\
\text { tion }\end{array}$ & $\begin{array}{c}\text { NSRDB } \\
\text { Class }\end{array}$ & $\begin{array}{l}\text { Pool } \\
\text { Years }\end{array}$ \\
\hline 724117 & WISE/LONESOME PINE & VA & 36.983 & -82.533 & -5 & 817 & III & 11 \\
\hline 785430 & $\begin{array}{l}\text { CHARLOTTE AMALIE } \\
\text { HARRY S TRUM }\end{array}$ & VI & 18.350 & -64.967 & -4 & 6 & II & 12 \\
\hline 726170 & $\begin{array}{l}\text { BURLINGTON } \\
\text { INTERNATIONAL AP }\end{array}$ & VT & 44.467 & -73.150 & -5 & 101 & I & 24 \\
\hline 726145 & MONTPELIER AP & VT & 44.200 & -72.567 & -5 & 343 & II & 12 \\
\hline 725165 & RUTLAND STATE & VT & 43.517 & -72.950 & -5 & 246 & II & 12 \\
\hline 726115 & SPRINGFIELD/HARTNES & VT & 43.350 & -72.517 & -5 & 176 & III & 10 \\
\hline 727976 & BELLINGHAM INTL AP & WA & 48.800 & -122.533 & -8 & 45 & II & 12 \\
\hline 727928 & BREMERTON NATIONAL & WA & 47.483 & -122.750 & -8 & 137 & II & 12 \\
\hline 727826 & EPHRATA AP FCWOS & WA & 47.300 & -119.517 & -8 & 384 & II & 12 \\
\hline 727855 & FAIRCHILD AFB & WA & 47.633 & -117.650 & -8 & 743 & II & 12 \\
\hline 727856 & FELTS FLD & WA & 47.683 & -117.317 & -8 & 610 & II & 12 \\
\hline 742070 & GRAY AAF & WA & 47.083 & -122.583 & -8 & 90 & II & 12 \\
\hline 727840 & HANFORD & WA & 46.567 & -119.600 & -8 & 223 & II & 12 \\
\hline 727923 & HOQUIAM AP & WA & 46.983 & -123.933 & -8 & 4 & II & 12 \\
\hline 727924 & KELSO WB AP & WA & 46.133 & -122.900 & -8 & 5 & II & 12 \\
\hline 727827 & $\begin{array}{l}\text { MOSES LAKE GRANT } \\
\text { COUNTY AP }\end{array}$ & WA & 47.200 & -119.317 & -8 & 364 & II & 12 \\
\hline 727920 & OLYMPIA AIRPORT & WA & 46.967 & -122.900 & -8 & 63 & I & 24 \\
\hline 727845 & PASCO & WA & 46.267 & -119.117 & -8 & 136 & II & 12 \\
\hline 727857 & PULLMAN/MOSCOW RGNL & WA & 46.750 & -117.117 & -8 & 778 & II & 12 \\
\hline 727970 & $\begin{array}{l}\text { QUILLAYUTE STATE } \\
\text { AIRPORT }\end{array}$ & WA & 47.933 & -124.567 & -8 & 55 & I & 24 \\
\hline 727934 & RENTON MUNI & WA & 47.483 & -122.217 & -8 & 10 & II & 12 \\
\hline 727935 & $\begin{array}{l}\text { SEATTLE BOEING FIELD } \\
\text { [ISIS] }\end{array}$ & WA & 47.680 & -122.250 & -8 & 20 & II & 12 \\
\hline 727930 & $\begin{array}{l}\text { SEATTLE SEATTLE- } \\
\text { TACOMA INTL A }\end{array}$ & WA & 47.467 & -122.317 & -8 & 122 & I & 24 \\
\hline 727937 & SNOHOMISH CO & WA & 47.900 & -122.283 & -8 & 189 & II & 12 \\
\hline 727850 & $\begin{array}{l}\text { SPOKANE INTERNATIONAL } \\
\text { AP [CHENEY - UO] }\end{array}$ & WA & 47.490 & -117.589 & -8 & 777 & I & 24 \\
\hline 727815 & STAMPEDE PASS & WA & 47.283 & -121.333 & -8 & 1206 & II & 12 \\
\hline 742060 & TACOMA MCCHORD AFB & WA & 47.150 & -122.483 & -8 & 88 & II & 12 \\
\hline 727938 & TACOMA NARROWS & WA & 47.267 & -122.583 & -8 & 91 & II & 12 \\
\hline 726988 & $\begin{array}{l}\text { THE DALLES MUNICIPAL } \\
\text { ARPT }\end{array}$ & WA & 45.617 & -121.150 & -8 & 73 & II & 12 \\
\hline 727926 & TOLEDO-WINLOCK MEM & WA & 46.483 & -122.800 & -8 & 113 & II & 12 \\
\hline 727846 & $\begin{array}{l}\text { WALLA WALLA CITY } \\
\text { COUNTY AP }\end{array}$ & WA & 46.100 & -118.283 & -8 & 355 & II & 12 \\
\hline 727825 & WENATCHEE/PANGBORN & WA & 47.400 & -120.200 & -8 & 379 & II & 12 \\
\hline 690230 & WHIDBEY ISLAND NAS & WA & 48.350 & -122.667 & -8 & 10 & II & 12 \\
\hline 727885 & WILLIAM R FAIRCHILD & WA & 48.117 & -123.500 & -8 & 91 & III & 12 \\
\hline 727810 & YAKIMA AIR TERMINAL & WA & 46.567 & -120.550 & -8 & 324 & $\mathrm{I}$ & 24 \\
\hline 726626 & ANTIGOILANG(AWOS) & WI & 45.150 & -87.150 & -5 & 464 & III & 10 \\
\hline 726457 & APPLETON/OUTAGAMIE & WI & 44.250 & -88.517 & -6 & 280 & II & 12 \\
\hline 726435 & EAU CLAIRE COUNTY AP & WI & 44.867 & -91.483 & -6 & 271 & I & 24 \\
\hline 726450 & $\begin{array}{l}\text { GREEN BAY AUSTIN } \\
\text { STRAUBEL INT }\end{array}$ & WI & 44.483 & -88.133 & -6 & 209 & I & 24 \\
\hline
\end{tabular}




\begin{tabular}{|c|c|c|c|c|c|c|c|c|}
\hline USAF & Station Name & State & $\begin{array}{l}\text { Lati- } \\
\text { tude }\end{array}$ & $\begin{array}{l}\text { Longi- } \\
\text { tude }\end{array}$ & $\begin{array}{l}\text { Time } \\
\text { Zone }\end{array}$ & $\begin{array}{c}\text { Eleva- } \\
\text { tion }\end{array}$ & $\begin{array}{l}\text { NSRDB } \\
\text { Class }\end{array}$ & $\begin{array}{l}\text { Pool } \\
\text { Years }\end{array}$ \\
\hline 726415 & JANESVILLE/ROCK CO. & WI & 42.617 & -89.033 & -6 & 246 & III & 10 \\
\hline 726430 & $\begin{array}{l}\text { LA CROSSE MUNICIPAL } \\
\text { ARPT }\end{array}$ & WI & 43.867 & -91.250 & -6 & 198 & I & 24 \\
\hline 726416 & LONE ROCK FAA AP & WI & 43.200 & -90.183 & -6 & 219 & II & 12 \\
\hline 726410 & $\begin{array}{l}\text { MADISON DANE CO } \\
\text { REGIONAL ARPT [ISIS] }\end{array}$ & WI & 43.130 & -89.330 & -6 & 262 & I & 24 \\
\hline 726455 & MANITOWAC MUNI AWOS & WI & 44.133 & -87.683 & -6 & 198 & II & 12 \\
\hline 726574 & MARSHFIELD MUNI & WI & 44.633 & -90.183 & -6 & 389 & III & 12 \\
\hline 726400 & $\begin{array}{l}\text { MILWAUKEE MITCHELL INTL } \\
\text { AP }\end{array}$ & WI & 42.950 & -87.900 & -6 & 205 & 1 & 24 \\
\hline 726404 & MINOCQUA/WOODRUFF & WI & 45.933 & -89.733 & -6 & 496 & II & 12 \\
\hline 726465 & MOSINEE/CENTRAL WI & WI & 44.783 & -89.667 & -6 & 389 & II & 12 \\
\hline 726468 & PHILLIPS/PRICE CO. & WI & 45.700 & -90.400 & -6 & 449 & II & 12 \\
\hline 727415 & RHINELANDER ONEIDA & WI & 45.633 & -89.467 & -6 & 507 & II & 12 \\
\hline 726467 & RICE LAKE MUNICIPAL & WI & 45.483 & -91.717 & -6 & 347 & III & 10 \\
\hline 726458 & STURGEON BAY & WI & 44.850 & -87.417 & -5 & 221 & II & 12 \\
\hline 726464 & WATERTOWN & WI & 43.167 & -88.717 & -6 & 254 & III & 10 \\
\hline 726463 & WAUSAU MUNICIPAL ARPT & WI & 44.917 & -89.633 & -6 & 366 & II & 12 \\
\hline 726456 & WITTMAN RGNL & WI & 43.983 & -88.550 & -6 & 253 & II & 12 \\
\hline 724120 & $\begin{array}{l}\text { BECKLEY RALEIGH CO MEM } \\
\text { AP }\end{array}$ & WV & 37.800 & -81.117 & -5 & 763 & I & 12 \\
\hline 724125 & $\begin{array}{l}\text { BLUEFIELD/MERCER CO } \\
\text { [NREL] }\end{array}$ & WV & 37.270 & -81.240 & -5 & 803 & II & 12 \\
\hline 724140 & $\begin{array}{l}\text { CHARLESTON YEAGER } \\
\text { ARPT }\end{array}$ & WV & 38.383 & -81.583 & -5 & 310 & I & 24 \\
\hline 724170 & $\begin{array}{l}\text { ELKINS ELKINS-RANDOLPH } \\
\text { CO ARP }\end{array}$ & WV & 38.883 & -79.850 & -5 & 594 & 1 & 24 \\
\hline 724175 & HARRISON MARION RGN & WV & 39.283 & -80.233 & -5 & 380 & II & 12 \\
\hline 724250 & $\begin{array}{l}\text { HUNTINGTON TRI-STATE } \\
\text { ARPT }\end{array}$ & WV & 38.383 & -82.550 & -5 & 253 & I & 24 \\
\hline 724127 & LEWISBURG/GREENBRIE & WV & 37.867 & -80.400 & -5 & 702 & II & 12 \\
\hline 724177 & $\begin{array}{l}\text { MARTINSBURG EASTERN } \\
\text { WV REG AP }\end{array}$ & WV & 39.400 & -77.983 & -5 & 162 & II & 12 \\
\hline 724176 & MORGANTOWN HART FIELD & WV & 39.650 & -79.917 & -5 & 378 & II & 12 \\
\hline 724273 & $\begin{array}{l}\text { PARKERSBURG WOOD } \\
\text { COUNTY AP }\end{array}$ & WV & 39.350 & -81.433 & -5 & 253 & II & 12 \\
\hline 724275 & $\begin{array}{l}\text { WHEELING OHIO COUNTY } \\
\text { AP }\end{array}$ & WV & 40.183 & -80.650 & -5 & 359 & II & 12 \\
\hline 725690 & $\begin{array}{l}\text { CASPER NATRONA CO INTL } \\
\text { AP }\end{array}$ & WY & 42.900 & -106.467 & -7 & 1627 & I & 24 \\
\hline 725640 & $\begin{array}{l}\text { CHEYENNE MUNICIPAL } \\
\text { ARPT }\end{array}$ & WY & 41.150 & -104.800 & -7 & 1867 & I & 24 \\
\hline 726700 & CODY MUNI (AWOS) & WY & 44.517 & -109.017 & -7 & 1553 & II & 12 \\
\hline 725775 & EVANSTON/BURNS FLD & WY & 41.283 & -111.033 & -7 & 2183 & II & 12 \\
\hline 726650 & GILLETTE/GILLETTE-C & WY & 44.350 & -105.533 & -7 & 1230 & II & 12 \\
\hline 725776 & JACKSON HOLE & WY & 43.600 & -110.733 & -7 & 2016 & II & 12 \\
\hline 725760 & LANDER HUNT FIELD & WY & 42.817 & -108.733 & -7 & 1694 & $\mathrm{I}$ & 24 \\
\hline 45 & $\begin{array}{l}\text { LARAMIE GENERAL BREES } \\
\text { FIELD }\end{array}$ & WY & 317 & 683 & -7 & 15 & II & 12 \\
\hline 725745 & RAWLINS MUNICIPAL AP & WY & 41.800 & -107.200 & -7 & 2053 & II & 12 \\
\hline
\end{tabular}




\begin{tabular}{|c|l|c|c|c|c|c|c|c|}
\hline USAF & \multicolumn{1}{|c|}{ Station Name } & State & $\begin{array}{c}\text { Lati- } \\
\text { tude }\end{array}$ & $\begin{array}{c}\text { Longi- } \\
\text { tude }\end{array}$ & $\begin{array}{c}\text { Time } \\
\text { Zone }\end{array}$ & $\begin{array}{c}\text { Eleva- } \\
\text { tion }\end{array}$ & $\begin{array}{c}\text { NSRDB } \\
\text { Class }\end{array}$ & $\begin{array}{c}\text { Pool } \\
\text { Years }\end{array}$ \\
\hline 725765 & RIVERTON MUNICIPL AP & WY & 43.050 & -108.450 & -7 & 1663 & II & 12 \\
\hline 725744 & $\begin{array}{l}\text { ROCK SPRINGS ARPT } \\
\text { [GREEN RIVER - UO] }\end{array}$ & WY & 41.460 & -109.440 & -7 & 1000 & $\mathrm{I}$ & 24 \\
\hline 726660 & SHERIDAN COUNTY ARPT & WY & 44.767 & -106.967 & -7 & 1208 & $\mathrm{I}$ & 24 \\
\hline 726665 & WORLAND MUNICIPAL & WY & 43.967 & -107.950 & -7 & 1294 & II & 12 \\
\hline
\end{tabular}




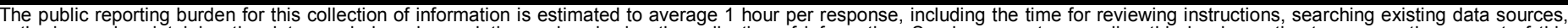

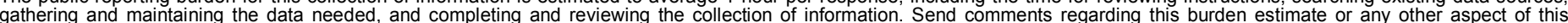

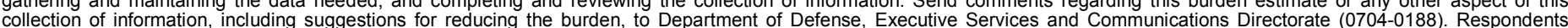

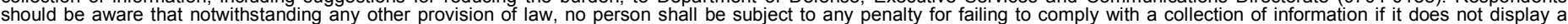

should be aware that notwithstanding

PLEASE DO NOT RETURN YOUR FORM TO THE ABOVE ORGANIZATION.

\begin{tabular}{l|l|l|l} 
1. REPORT DATE $(D D-M M-Y Y Y Y)$ & 2. & REPORT TYPE & 3. DATES COVERED (FrOm - TO)
\end{tabular}

Revised May 2008

Technical Report

4. TITLE AND SUBTITLE
Users Manual for TMY3 Data Sets

5a. CONTRACT NUMBER

DE-AC36-99-G010337

5b. GRANT NUMBER

5c. PROGRAM ELEMENT NUMBER

6. AUTHOR(S)

S. Wilcox and W. Marion

5d. PROJECT NUMBER

NREL/TP-581-43156

5e. TASK NUMBER

PVA7-6101

5f. WORK UNIT NUMBER

7. PERFORMING ORGANIZATION NAME(S) AND ADDRESS(ES)

National Renewable Energy Laboratory

1617 Cole Blvd.

8. PERFORMING ORGANIZATION REPORT NUMBER

Golden, CO 80401-3393

NREL/TP-581-43156

9. SPONSORING/MONITORING AGENCY NAME(S) AND ADDRESS(ES)

10. SPONSOR/MONITOR'S ACRONYM(S) NREL

11. SPONSORING/MONITORING AGENCY REPORT NUMBER

12. DISTRIBUTION AVAILABILITY STATEMENT

National Technical Information Service

U.S. Department of Commerce

5285 Port Royal Road

Springfield, VA 22161

13. SUPPLEMENTARY NOTES

14. ABSTRACT (Maximum 200 Words)

This users manual describes how to obtain and interpret the data in the Typical Meteorological Year version 3

(TMY3) data sets. These data sets are an update to the TMY2 data released by NREL in 1994.

15. SUBJECT TERMS

TMY; typical meteorological year; NSRDB; National Solar Radiation Data Base; TMY3

\begin{tabular}{l}
\hline \multicolumn{3}{|l|}{ 16. SECURITY CLASSIFICATION OF: } \\
\hline \begin{tabular}{l|l|l|} 
a. REPORT & b. ABSTRACT & c. THIS PAGE \\
Unclassified & Unclassified & Unclassified \\
& & \\
\hline
\end{tabular} \\
\hline
\end{tabular}

\begin{tabular}{|c|c|} 
17. LIMITATION & 18. \\
OF ABSTRACT & OF PAGES \\
UL &
\end{tabular}

19a. NAME OF RESPONSIBLE PERSON

19b. TELEPHONE NUMBER (Include area code) 